\title{
Concrete Release Protocol Case Studies for Decommissioning Work at the Idaho National Engineering and Environmental Laboratory
}

Environmental Assessment Division Argonne National Laboratory

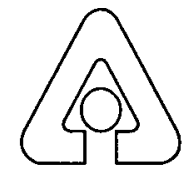

Operated by The University of Chicago, under Contract W-31-109-Eng-38, for the 


\section{Argonne National Laboratory}

Argonne National Laboratory, with facilities in the states of Illinois and Idaho, is owned by the United States Government and operated by The University of Chicago under the provisions of a contract with the Department of Energy.

This technical memorandum is a product of Argonne's Environmental Assessment Division (EAD). For information on the division's scientific and engineering activities, contact:

Director, Environmental Assessment Division

Argonne National Laboratory

Argonne, Illinois 60439-4815

Telephone (630) 252-3107

Presented in this technical memorandum are preliminary results of ongoing work or work that is more limited in scope and depth than that described in formal reports issued by the EAD.

Publishing support services were provided by Argonne's Information and Publishing Division (for more information, see IPD's home page: http://www.ipd.anl.gov/).

\section{Disclaimer}

This report was prepared as an account of work sponsored by an agency of the United States Government. Neither the United States Government nor any agency thereof, nor The University of Chicago, nor any of their employees or officers, makes any warranty, express or implied, or assumes any legal liability or responsibility for the accuracy, completeness, or usefulness of any information, apparatus, product, or process disclosed, or represents that its use would not infringe privately owned rights. Reference herein to any specific commercial product, process, or service by trade name, trademark, manufacturer, or otherwise does not necessarily constitute or imply its endorsement, recommendation, or favoring by the United States Government or any agency thereof. The views and opinions of document authors expressed herein do not necessarily state or reflect those of the United States Government or any agency thereof, Argonne National Laboratory, or The University of Chicago. 


\section{Concrete Release Protocol Case Studies for Decommissioning Work at the Idaho National Engineering and Environmental Laboratory}

by S. Kamboj, J. Arnish, S-Y. Chen, F.L. Parker, ${ }^{*}$ A.M. Phillips, ${ }^{* *}$ J.L. Tripp, ${ }^{* *}$ and R.H. Meservey**

Environmental Assessment Division

Argonne National Laboratory, 9700 South Cass Avenue, Argonne, Illinois 60439

September 2000

Work sponsored by U.S. Department of Energy, Office of Environmental Management, Office of Project Completion, Deactivation and Decommissioning Focus Area

* Parker is affiliated with Vanderbilt University, Nashville, Tenn.

** Phillips, Tripp, and Meservey are affiliated with Idaho National Engineering and Environmental Laboratory, Idaho Falls, Idaho. 
This report is printed on recycled paper. 


\section{CONTENTS}

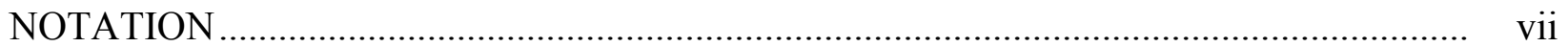

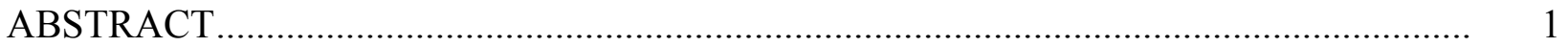

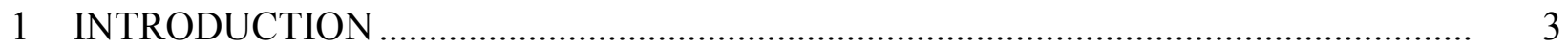

2 HISTORY AND BACKGROUND OF CFA STP ……………………………………..... 6

2.1 CFA-691 Pumphouse ................................................................................................ 6

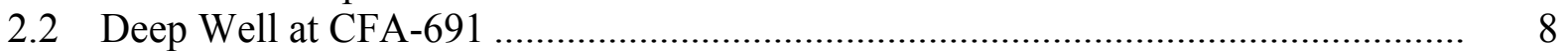

2.3 Auxiliary STP Structures ................................................................................ 8

2.3.1 Dorr Primary and Secondary Clarifiers ....................................................... 8

2.3.2 Trickle Filter ................................................................................... 9

2.3.3 Digester ....................................................................................... 9

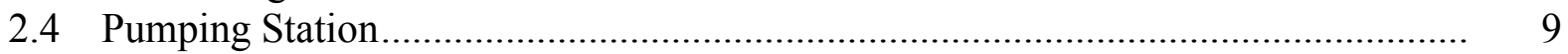

3 RADIOLOGICAL AND CHEMICAL CHARACTERIZATION OF CFA STP FACILITY STRUCTURES................................................................. 10

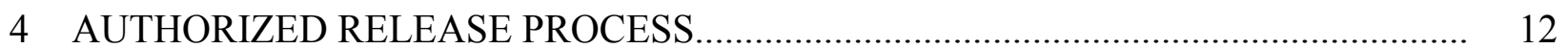

4.1 Defining Alternatives...................................................................................... 12

4.1.1 Alternative A: Decontaminate, Crush, and Reuse ………........................... 13

4.1.2 Alternative B: Crush and Reuse without Decontamination.......................... 13

4.1.3 Alternative C: Decontaminate, Demolish, and Disposal

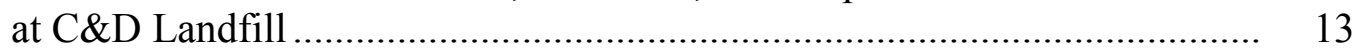

4.1.4 Alternative D: Demolish and Disposal at C\&D Landfill............................... 13

4.1.5 Alternative E: Demolish and Disposal at a Low-Level Waste Disposal Facility ........................................................................ 14

4.2 Analyzing Alternatives ................................................................................. 14

4.2.1 Cost Analysis ...................................................................................... 15

4.2.2 Radiological Dose Analysis .................................................................... 19

4.3 Results and Conclusions ............................................................................... 20

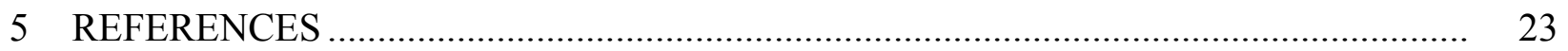

APPENDIX A: Application for the Development of Authorized Release Limits for Concrete from the Trickle Filter — Generic Case ................................... A-1

APPENDIX B: Application for the Development of Authorized Release Limits for Concrete from the Trickle Filter - INEEL-Specific Case....................... B-1 


\section{CONTENTS (Cont.)}

APPENDIX C: Generic Cost and Dose Analysis for Concrete Disposition

from Trickle Filter Structure

C-1

APPENDIX D: INEEL-Specific Cost and Dose Analysis for Concrete Disposition from Trickle Filter Structure

D-1

\section{TABLES}

1 Concrete Disposition Alternatives and Parameters for Different

Structures of the CFA STP

2 Characterization Data for Trickle Filter, Primary Clarifier, Secondary Clarifier, and CFA-691 Pumphouse

3 Characteristics of Technologies Used for Removing Fixed

Subsurface Concrete Contamination

4a Generic Cost Analysis for Different Alternatives Considered for Concrete Disposition....

4b INEEL-Specific Cost Analysis for Different Alternatives Considered

for Concrete Disposition.

5a Generic Summary of Cost and Radiological Impacts

for Different Alternatives

$5 b \quad$ INEEL-Specific Summary of Cost and Radiological Impacts for Different Alternatives

C.1 Cost Assumptions for Trickle Filter Disposal Alternatives for a Generic Case C-4

C.2 Cost Calculations for Decontamination, Demolition, Packaging, Transportation, and Disposal

C.3 Unit Dose Factors from Concrete Protocol Report for Radionuclides Found at Central Facility Area 691

C.4 Measured Radionuclide Concentration in the Sediment Sample from the Trickle Filter Structure 


\section{TABLES (Cont.)}

C.5 Residual Radionuclide Concentration in Trickle Filter Concrete after Decontamination

C.6 Trickle Filter Decontaminated Concrete Doses to the Construction Worker, Driver, Landfill Worker, Transportation Population, and Future Resident...

C.7 Radionuclide Concentration in Trickle Filter Concrete with No

Decontamination

C.8 Trickle Filter Contaminated Concrete Doses to the Construction Worker, Driver, Landfill Worker, Transportation Population, and Future Resident.

D.1 Cost Assumptions for Trickle Filter Disposal Alternatives for INEEL-Specific Case

D.2 Cost Calculations for Decontamination, Demolition, Packaging, Transportation, and Disposal

D.3 Unit Dose Factors from Concrete Protocol Report for Radionuclides Found at Central Facility Area 691

D.4 Measured Radionuclide Concentration in the Sediment Sample from the Trickle Filter Structure

D.5 Residual Radionuclide Concentration in Trickle Filter Concrete after Decontamination

D.6 Trickle Filter Decontaminated Concrete Doses to the Construction Worker, Driver, Landfill Worker, Transportation Population, and Future Resident.

D.7 Radionuclide Concentration in Trickle Filter Concrete with No

Decontamination

D.8 Trickle Filter Contaminated Concrete Doses to the Construction Worker, Driver, Landfill Worker, Transportation Population, and Future Resident.

\section{FIGURE}

1 Diagram of the CFA Sewage Treatment Plant 


\section{NOTATION}

The following is a list of the abbreviations used in this rpeort.

BBWI Bechtel BWXT Idaho, LLC

CERCLA Comprehensive Environmental Response, Compensation, and Liability Act

CFA Central Facilities Area

CFR Code of Federal Regulations

D\&D decontamination and dismantlement

DOE U.S. Department of Energy

DOE-ID U.S. Department of Energy-Idaho Field Office

INEEL Idaho National Engineering and Environmental Laboratory

LLW low level (radioactive) waste

MOA Memorandum of Agreement

PNNL Pacific Northwest National Laboratory

RRWAC Reusable Property, Recyclable Materials, and Waste Acceptance Criteria

RWMC Radioactive Waste Management Complex

STP sewage treatment plant 


\title{
CONCRETE RELEASE PROTOCOL CASE STUDIES FOR DECOMMISSIONING WORK AT THE IDAHO NATIONAL ENGINEERING AND ENVIRONMENTAL LABORATORY
}

\begin{abstract}
U.S. Department of Energy (DOE) Order 5400.5, "Radiation Protection of the Public and Environment" contains provisions pertinent to releasing potentially radioactive materials from DOE facilities for reuse or recycle. A process of "authorized" release for materials recovered from radiation areas is permitted under Order 5400.5 and the proposed rule in Title 10, Part 834, of the Code of Federal Regulations (10 CFR Part 834) 1 A generic disposition protocol to facilitate release of concrete under these provisions has been developed. This report analyzes the application of that generic protocol to site-specific cases at the Idaho National Engineering and Environmental Laboratory (INEEL).
\end{abstract}

The potential radiological doses and costs for several concrete disposition alternatives for the sewage treatment plant (STP) at the Central Facilities Area (CFA) of INEEL were evaluated in this analysis. Five disposition alternatives were analyzed for the concrete: (A) decontaminate, crush, and reuse; (B) crush and reuse without decontamination; (C) decontaminate, demolish, and dispose of at a nonradiological landfill; (D) demolish and dispose of at a nonradiological landfill without decontamination; and (E) demolish and dispose of at a low-level radioactive waste (LLW) facility. The analysis was performed for disposition of concrete from four INEEL structures: (1) trickle filter, (2) primary clarifier, (3) secondary clarifier, and (4) CFA-691 pumphouse for a generic case (based on default parameters from the disposition protocol) and an INEEL-specific case (based on INEEL-specific parameters).

The results of the analysis indicated that Alternatives B and D would incur the lowest cost and result in a dose less than $1 \mathrm{mrem} / \mathrm{yr}$ (except for the trickle filter, the dose for which was estimated at $1.9 \mathrm{mrem} / \mathrm{yr}$ ) for nonradiological workers. The analysis indicated that the main contributor to the radiological dose would be cobalt -60 contamination in the concrete. A characterization conducted in 1996 was used in the analysis; therefore, because of radioactive decay, the resultant doses to receptors (now or later) would be less than the values reported in this analysis. For the generic case study, costs associated with Alternatives A and $\mathrm{C}$ were shown to be much smaller than for Alternative E. For the INEELspecific case, in general, costs were much higher for Alternatives $\mathrm{A}$ and $\mathrm{C}$ than for Alternative E because of on-site disposal with zero disposal cost.

1 Recycling of metals into general commerce under these provisions has been suspended by DOE as of July 13, 2000. 


\section{INTRODUCTION}

The U.S. Department of Energy-Idaho Field Office (DOE-ID) is committed to the cleanup of the inactive, contaminated nuclear facilities and noncontaminated support facilities at the Idaho National Engineering and Environmental Laboratory (INEEL) near Idaho Falls, Idaho.

DOE-ID had asked Bechtel BWXT Idaho, LLC (BBWI), to be responsible for the decontamination and dismantlement (D\&D) program at INEEL. The objective of the program is to remove contamination from surplus facilities at INEEL and obtain release of the facilities and sites for unrestricted use. The sewage treatment plant (STP), located at the Central Facilities Area (CFA) of INEEL, has been listed as one of the INEEL surplus facilities.

The National Environmental Policy Act (NEPA) impact evaluation process is used for all work at INEEL, including D\&D. When the NEPA process calls for review and/or approval by local communities, D\&D work receives these reviews. In addition, D\&D work conducted at INEEL is performed with internal and DOE-ID review and approval.

Typically, a Decision Analysis and Characterization Report is written for such projects by the D\&D Operations Project Manager. That document is reviewed and approved by the INEEL D\&D Operations Department Manager and by DOE-ID. Next, a D\&D plan is formulated, and it must be approved internally and by DOE-ID before the work begins. The work is then performed according to the approved D\&D plan.

During D\&D projects, no radioactive material above regulatory limits (DOE Order 5400.5) is released to the environment (neither on the INEEL site nor on private sector). Radioactive material is disposed of in an appropriate disposal facility (low-level radioactive waste [LLW] is sent to the INEEL Radioactive Waste Management Complex, [RWMC]), while noncontaminated materials are disposed of at the INEEL sanitary landfill. Equipment or metal can be reused as scrap if a $100 \%$ survey is performed and no contamination is found. Reuse or disposal of these materials is conducted according to the INEEL Reusable Property, Recyclable Materials, and Waste Acceptance Criteria (RRWAC). The RRWAC define the on-site disposal requirements for contaminated and noncontaminated materials.

When an area at INEEL is designated as a Comprehensive Environmental Response, Compensation, and Liability Act (CERCLA) site, the CERCLA remediation process, including review by the local community, is initiated. However, the CERCLA process is not used for D\&D work at INEEL because a decision was made that the facilities being decommissioned are real property, which is not covered under CERCLA.2

2 At some DOE sites (e.g., Pacific Northwest National Laboratory [PNNL]), D\&D activities are performed under CERCLA. 
When D\&D work is conducted near or in association with a CERCLA site, a Memorandum of Agreement (MOA) is written to delineate what part of the work is CERCLA and what part is D\&D. Even though D\&D of buildings is not done under CERCLA, any releases or spills to soil near the D\&D site do come under CERCLA jurisdiction. For example, at the CFA STP, D\&D of the buildings was not performed under CERCLA, but the contaminated soil adjacent to the buildings and the septic system drain field was cleaned up under CERCLA. In this case, a MOA was written to define the boundaries of each portion of the project.

In 1996, radiation surveys and radiological and hazardous chemical samples were taken and analyzed to characterize any contamination present at the CFA STP (Klassy and Brown 1997). Radiological characterization consisted of direct radiation measurements and analysis of samples to identify radionuclides and determine the specific activity of each.

The information gained from the characterization effort was used as the basis of preliminary assessment to plan the final disposition of materials generated by the planned CFA STP D\&D project. Compounds detected during laboratory analysis were compared to action levels to determine material disposition.

The D\&D plan (Thiel and Allen 1998) identified the tasks that were to be performed for various structures, including the STP pumphouse (CFA-691), auxiliaries adjacent to the pump house (CFA-766), pumping station (CFA-657), septic tank (CFA-716), and support structures and utilities located at the CFA of INEEL. The objectives of this D\&D project were to (1) eliminate potential safety hazards, (2) eliminate the potential for exposure to hazardous materials, (3) return the site to its original condition, and (4) release the site for unrestricted use.

Decommissioning of the CFA 691 STP was completed in 2000 (Thiel 2000). Table 1 lists the disposition alternatives selected for different concrete structures, total concrete volume generated, concrete volume sent to the LLW disposal facility and sanitary landfill, removal method used, and the container type used for concrete disposition.

Millions of cubic meters of concrete will be removed from nuclear facilities across the DOE complex within the next few decades as a result of D\&D activities. To clarify and implement DOE's release provisions, protocols are being developed to assist in obtaining authorization to release the concrete material for unrestricted use. The protocol used for the case studies reported here (Arnish et al. 2000) contains 10 steps to reach an appropriate decision on disposition alternatives. The purpose of this analysis was to use the 10-step process for concrete structures (digester, trickle filter and primary tank, secondary tank and 691 pumphouse, deep well at CFA-691, 657 pumphouse at the CFA STP) to support an appropriate disposition alternative. The identified alternative from the concrete protocol is compared with the disposition alternative already used in the D\&D of this facility. 
TABLE 1 Concrete Disposition Alternatives and Parameters for Different Structures of the CFA STP

\begin{tabular}{|c|c|c|c|c|c|}
\hline Structure & $\begin{array}{c}\text { Total Concrete } \\
\text { Volume }\left(\mathrm{ft}^{3}\right)\end{array}$ & $\begin{array}{l}\text { LLW Concrete } \\
\text { Volume }\left(\mathrm{ft}^{3}\right)\end{array}$ & $\begin{array}{c}\text { Sanitary Landfill } \\
\text { Concrete } \\
\text { Volume }\left(\mathrm{ft}^{3}\right) \\
\end{array}$ & $\begin{array}{l}\text { Removal } \\
\text { Method }\end{array}$ & $\begin{array}{c}\text { Container } \\
\text { Type }^{\mathrm{a}}\end{array}$ \\
\hline $\begin{array}{l}\text { Trickle filter and } \\
\text { primary tank }\end{array}$ & $\begin{array}{l}\text { Trickler: } 1,546 \\
\text { Primary: } 951\end{array}$ & 335 (total) & 2,162 & $\begin{array}{l}\text { Scabbling for } \\
\text { drum contents; } \\
\text { processor }^{b} \text { for } \\
\text { the rest }\end{array}$ & $\begin{array}{l}55 \text {-gal drums (2), } \\
\text { metal boxes (2), and } \\
\text { wooden box (1) }\end{array}$ \\
\hline $\begin{array}{l}\text { Secondary tank } \\
\text { and } 691 \text { pump- } \\
\text { house }\end{array}$ & $\begin{array}{l}\text { Secondary: } 951 \\
\text { Pumphouse: } \\
1495\end{array}$ & 3 (total) & 2,443 & Scabbling & 55-gal drum \\
\hline $\begin{array}{l}\text { Deep well (691) } \\
\text { (similar to a } \\
\text { sump pit) }\end{array}$ & 310 & 310 & None & Processor & SSCs \\
\hline 657 pumphouse & 180 & 180 & None & Processor & SSCs \\
\hline
\end{tabular}

a Larger pieces demolished with the processor are usually disposed of in soft-sided containers (SSC). In this case, there were surplus wooden and metal boxes, which were available at no cost, so some of those were used. Small chunks of concrete that have been scabbled are usually disposed of in 55-gal drums. SSCs weigh $85 \mathrm{lb}$ each when empty. The volume of full bags varies. Metal boxes are $4 \times 3 \times 8$ feet $\left(96 \mathrm{ft}^{3}\right)$ each; wooden boxes are $4 \times 4 \times 8$ feet, $\left(128 \mathrm{ft}^{3}\right)$ each; and 55 -gal drums hold $7.35 \mathrm{ft}^{3}$ each.

b The processor is a large track-hoe with crushing jaws at the end, used for demolition of structures. 


\section{HISTORY AND BACKGROUND OF CFA STP}

The STP facility was located at the northeastern perimeter of the CFA at INEEL. It began operating in 1944 to treat and dispose of CFA process wastewater. As originally built by the Navy, the facility consisted of a septic tank (CFA-716) and drain field with four distribution areas. The pumping station (CFA-657), sludge drying beds (CFA-766), trickling filter, primary and secondary clarifiers, and digester were constructed in 1953. Figure 1 shows the CFA sewage treatment plant before decommissioning.

In 1995, an upgraded INEEL sewer system, the CFA Waste Water Testing Laboratory (CFA-605) became operational, and the CFA STP was shutdown and placed on the list of surplus sites for D\&D. Since then, no additional sewage waste has been disposed of through the CFA-716 septic tank or drainfield.

Over the years it operated, the CFA STP handled both sanitary wastewater and waste received from several industrial sources at CFA, including chemical laboratories, craft shops, warehouses, photographic services, vehicle services, the medical dispensary, the maintenance repair shop, and old (CFA-669) and new (CFA-617) hot laundries.

Wastewater from both old and new laundries was discharged directly to the CFA STP. To avoid continued radiological contamination of sludge generated in the CFA STP, the line from the laundry to the CFA STP was abandoned in 1981, and laundry waste streams were discharged directly into the CFA-716 septic tank, bypassing the CFA STP.

Process knowledge, personal interviews, and analytical data were used to determine if CFA STP waste materials qualified as RCRA hazardous wastes. Hazardous waste determination was prepared by Klassy and Brown (1997). It was concluded that there had never been RCRA listed waste, as defined by 40 CFR 261 Subpart D, intentionally disposed to any sump, drain, or other facilities tied to the CFA STP, and the hazardous constituents present do not exceed the characteristics for toxicity. Sections 2.1 through 2.4 provide information about the different STP concrete structures.

\subsection{CFA-691 PUMPHOUSE}

The CFA STP pumphouse (CFA-691) was a two-story solid concrete building with a gross exterior area of $480 \mathrm{ft}^{2}$. The building was $23 \mathrm{ft}$ across the front and back, $21 \mathrm{ft}$ across the sides, extended about $11.5 \mathrm{ft}$ into the ground, and stood about $10 \mathrm{ft}$ from ground to the roof. The exterior walls and floors were concrete, and the roof was reinforced concrete. 


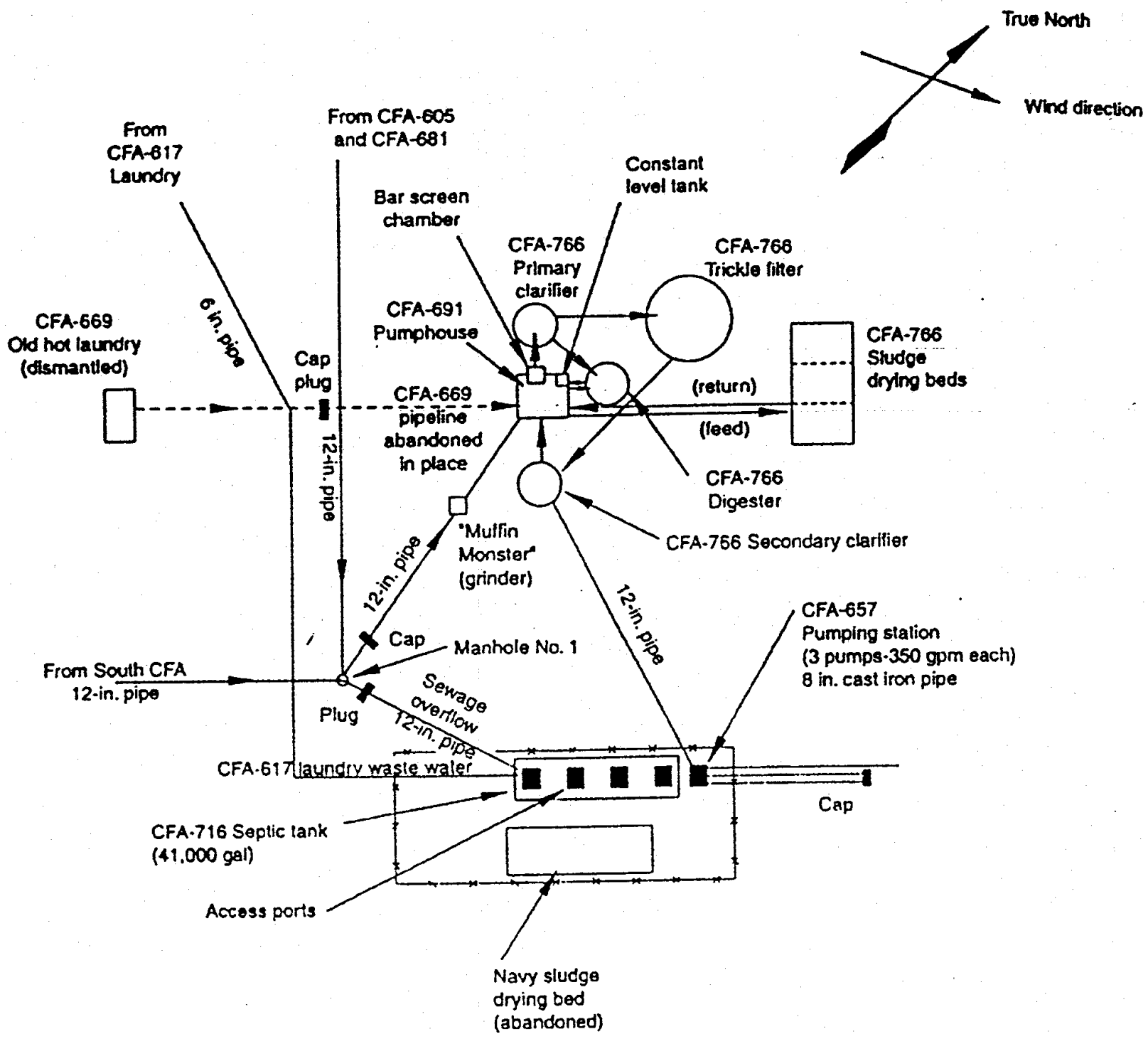

Note: Drawing is nol to scale

FIGURE 1 Diagram of the CFA Sewage Treatment Plant (adopted from Figure 3 of Thiel and Allen 1998) 
The pumphouse basement contained three pumps used to move raw sewage from the holding tank up to the screens and primary clarifier. One pump was used to recirculate liquid from the secondary clarifier to the primary clarifier and the trickle filter on weekends and other days when only small amounts of influents entered the plant. The other two pumps were used to pump sludge from the primary clarifier and the scum pit to the sludge digester, recirculate the sludge during the digestion process, and pump digested sludge to the drying beds.

\subsection{DEEP WELL AT CFA-691}

The deep well area was about $11 \mathrm{ft}$ deep by $14 \mathrm{ft}$ long by $5 \mathrm{ft}$ wide. During the characterization survey, the highest radiation reading of $9 \mathrm{mrem} / \mathrm{hr}$ was obtained from the pipe that came through the wall of the well. The deep well area had about $70 \mathrm{in}$. of water in one section.

\subsection{AUXILIARY STP STRUCTURES (CFA-766)}

CFA-766 was an outside area where auxiliary STP structures were located. These structures included the Dorr primary and secondary clarifiers, trickle filter, sludge drying bed, and digester (Figure 1).

\subsubsection{Dorr Primary and Secondary Clarifiers}

The Dorr primary and secondary clarifiers were two auxiliary structures located just northwest and northeast (respectively) of the pumphouse. Each clarifier (coalescent basin), was a 30,000 -gal concrete cylindrical basin about $24 \mathrm{ft}$ in diameter with sloping floors. The clarifier floors were made of 6-in.-thick concrete reinforced with welded wire mesh. An effluent channel at the top of each basin measuring $1 \mathrm{ft}$ wide by $2 \mathrm{ft}$ deep constituted the outer circumference. The outside concrete walls were approximately $10 \mathrm{ft}$ high by 9 in. thick down to the effluent channel, at which point they narrowed to a 6 -in. thickness. On top of each clarifier was a 3-ft-wide metal catwalk with $3 \frac{1}{2}-\mathrm{ft}$-high metal handrails.

Sewage flowed from the center of the Dorr primary clarifier out to a peripheral, notched collection weir. A continuously rotating arm on the liquid surface moved the floating materials into a scum collection basin leading to a scum pit. The sludge settled to the bottom of the clarifier and was scooped to the center by two arms and collected in a catch basin. It then pumped to the sludge digester. The clarified liquid from the weir went to a constant-level tank near the clarifier. Additional settling took place in the constant-level tank, and the solids were recycled back through the clarifier. The liquid was then transferred by gravity flow to the trickle

filter. The secondary clarifier received the percolated sewage from the trickle filter. The 
suspended solids settled to the bottom of the tank and were pumped back through the primary clarifier and trickle filter.

\subsubsection{Trickle Filter}

The trickle filter was located northwest of the pump house. It was a 50-ft-diameter, cylindrical-shaped concrete structure. The walls consisted of 8-ft, 2-in. high concrete topped with $5 \mathrm{ft}$ of wood, which surrounded the trickler. There was a 3- by 4-ft door for entry into the trickler. The structure had a 4-in.-thick concrete slab floor reinforced with welded wire mesh. On top of the concrete slab floor was a layer of concrete filter blocks covered with $6 \mathrm{ft}$ of rock fill. The sewage, under gravity, came up through a line in the center of the bed and ran out openings in four distribution pipes. Percolated sewage was collected in a filter bottom system and transferred to the Dorr secondary clarifier.

\subsubsection{Digester}

The digester was an underground concrete tank with a sloping bottom. The walls were 9 in. thick, and the sloping floor was 6-in.-thick concrete reinforced with welded wire mesh. The tank had a 20 -ft inside diameter and was $23 \mathrm{ft}$ deep. Sludge was periodically pumped from the collection point in the primary clarifier and scum pit to the digester. The sludge was circulated in the digester through recirculating lines until the microbial action was complete. Supernatant liquid was drawn off through a pipe for sludge sampling. The digester also had two heated overflow stacks outside the concrete tank. Overflow in these stacks was transferred back to the raw sewage holding tank for reprocessing. The digested sludge was pumped by plant operators to the sludge drying bed.

\subsection{PUMPING STATION (CFA-657)}

Pumping station (CFA-657) was a single-story wood frame building with a 11-ft 9-in. deep concrete basement of about $76 \mathrm{ft}^{2}$. The gross exterior of the main floor area was $92 \mathrm{ft}^{2}$. The exterior walls were covered with wood siding, and the floor was concrete. The roof had wooden shingles. The pumping station contained three pumps that each pumped 350 gallons per minute (gpm). 


\section{RADIOLOGICAL AND CHEMICAL CHARACTERIZATION OF CFA STP FACILITY STRUCTURES}

The sewage treatment plant was characterized in 1996 (Klassy and Brown 1997). The radiological characterization consisted of direct radiation measurements and collection and analysis of samples to identify radionuclides and determine the specific activity of each. Screening data (monitoring with field instruments, collection and analysis of smears, and direct radiation surveys) and definitive data (for laboratory radioanalytical analysis) were gathered.

Samples were collected in and around the CFA STP buildings and structures and analyzed to characterize for radioactive and chemical contaminants. Surface samples (smears) were analyzed to identify removable surface radioactive contamination, and radiological surveys were performed at points on and inside the structures to identify fixed surface radioactive contamination. The survey instruments used were the Ludlum $2 \mathrm{~A}$ for beta and gamma contamination and the NE Technology Electra for alpha contamination. The smears were counted on a gas proportional counter. The samples were taken from 23 locations for laboratory radioanalytic analysis (Klassy and Brown 1997).

Contamination of the building material was assumed to be equal to or less than contamination on surfaces inside of piping or containment structures. Table 2 shows the radionuclides detected in sediment or liquid samples from different structures (Klassy and Brown 1997). For some radionuclides, two results are shown. The first is for alpha analysis, and the second is for gamma analysis. No survey data were available for the 657 pumphouse. For the digester, beta/gamma surveys showed contamination levels ranging from 4,000 to 40,000 disintegrations per minute per 100 square centimeters $\left(\mathrm{dpm} / 100 \mathrm{~cm}^{2}\right)$; however, no material samples were collected and analyzed. 
TABLE 2 Characterization Data for Trickle Filter, Primary Clarifier, Secondary Clarifier, and CFA-691 Pumphouse ${ }^{a}$

\begin{tabular}{|c|c|c|c|c|c|c|}
\hline \multirow[b]{2}{*}{ Radionuclide } & \multirow[b]{2}{*}{$\begin{array}{c}\text { Trickle } \\
\text { Sediment } \\
(\mathrm{pCi} / \mathrm{g})\end{array}$} & \multicolumn{3}{|c|}{ Primary Clarifier } & \multirow{2}{*}{$\begin{array}{l}\text { Secondary } \\
\text { Clarifier } \\
\text { Liquid } \\
(\mathrm{pCi} / \mathrm{L})\end{array}$} & \multirow{2}{*}{$\begin{array}{l}\text { CFA-691 } \\
\text { Pumphouse } \\
\text { Sediment } \\
\text { (pCi/g) }\end{array}$} \\
\hline & & $\begin{array}{l}\text { Vacuum } \\
\text { Debris, } \\
\text { pCi/g) }\end{array}$ & $\begin{array}{c}\text { Sediment } \\
(\mathrm{pCi} / \mathrm{g})\end{array}$ & $\begin{array}{l}\text { Liquid } \\
(\mathrm{pCi} / \mathrm{L})\end{array}$ & & \\
\hline Am-241 & 0.302 & 0.0405 & $0.552,0.55$ & & 0.72 & 0.0285 \\
\hline $\mathrm{Pu}-238$ & 0.786 & 0.186 & 0.27 & & & 0.021 \\
\hline Pu-239 & 0.27 & 0.04435 & 0.41 & & & 0.012 \\
\hline $\mathrm{Ra}-226$ & 6.6 & 5.57 & 6.9 & & & 6.1 \\
\hline $\mathrm{U}-234$ & 5.14 & 7.57 & 7.78 & 0.22 & 2.23 & 5.28 \\
\hline U-235 & 0.342 & $1.17,0.43$ & $0.534,0.63$ & & $0.089,25.0$ & 0.357 \\
\hline U-238 & 16.2 & 5.8 & 15.8 & 0.156 & 1.24 & 8.49 \\
\hline Sr-90 & 8.11 & 11.0 & 0.609 & 7.85 & 4.77 & 7.56 \\
\hline Cs-137 & 74.0 & 19.3 & 1.48 & 26.3 & 19.0 & 2.8 \\
\hline Co-60 & 233 & 10.2 & 3.96 & & & 16.8 \\
\hline Eu-152 & 0.59 & & & & & 0.595 \\
\hline Eu-154 & & & & & & 0.36 \\
\hline Ru-103 & 0.27 & & & & & \\
\hline $\begin{array}{l}\text { Beta/gamma } \\
\text { scan range } \\
\left(\mathrm{dpm} / 100 \mathrm{~cm}^{2}\right)\end{array}$ & $\begin{array}{l}1,200- \\
9,600\end{array}$ & $\begin{array}{l}1,200- \\
25,000\end{array}$ & & & $\begin{array}{l}1,200- \\
80,000\end{array}$ & $\begin{array}{l}2,000-50,000 \\
\text { (main floor) } \\
800-15,000 \\
\text { (basement) } \\
2,400-32,000 \\
\text { (roof) }\end{array}$ \\
\hline
\end{tabular}

a When two values are given, the first is for alpha analysis, and the second is for gamma analysis. 


\section{AUTHORIZED RELEASE PROCESS}

Two case studies (one generic and one INEEL-specific) were used to illustrate the use of the concrete release protocol (Arnish et al. 2000) to develop authorized release limits and select disposition alternative(s) that minimize radiological doses to members of the public while also minimizing costs associated with D\&D activities for the CFA STP.

Appendix A (generic) and B (INEEL-specific) provide examples of the application for the development of authorized release limits for concrete from the trickle filter structure. (All the sections in the application form may not be required in a particular case study, but for the sake of completeness the entire application form is provided in these appendices.) Appendices C (generic) and D (INEEL-specific) provide detailed calculations used for all alternatives analyzed for the trickle filter.

The difference between the two (generic and INEEL-specific) case studies is that the INEEL-specific case study assumes that LLW is disposed of on-site at the RWMC. The RWMC does not charge a disposal fee for LLW from INEEL projects; therefore, the LLW disposal cost is zero. Since all transport would take place within the boundaries of the INEEL, the radiation dose to the population along the transportation corridor for LLW would be zero. In addition, INEEL-specific parameters for the construction and debris (C\&D) landfill were used as appropriate for specific disposal options.

\subsection{DEFINING ALTERNATIVES}

The concrete protocol provides seven disposition alternatives for the development of authorized release limits for concrete materials. The following five of those seven alternatives were considered for this case study. Alternatives involving entombing and reuse of the structure were not analyzed because D\&D required free release of this site.

- Alternative A: Decontaminate the concrete material, dispose of all LLW, and crush and reuse the decontaminated material.

- Alternative B: Crush and reuse the concrete material without decontamination.

- Alternative C: Decontaminate the concrete material, dispose of all LLW, demolish the structure or material, and dispose of the decontaminated material in a nonradiological landfill (C\&D landfill).

- Alternative D: Demolish (without decontamination) the concrete material and dispose of it in a nonradiological landfill (C\&D landfill). 
- Alternative E: Demolish the concrete material and dispose of all materials as LLW.

\subsubsection{Alternative A: Decontaminate, Crush, and Reuse}

This alternative would involve decontamination of the concrete material, disposal of the waste generated during decontamination at a LLW disposal facility on-site, and crushing and reusing the decontaminated concrete for roadbeds on-site. After removal of the contaminated concrete, the structure would be demolished, and the concrete crushed to allow for reuse. The waste generated during decontamination activities would be packed and transported to a LLW disposal facility. The radiological impacts to a construction worker associated with reuse of the concrete as roadbed material were analyzed for this alternative.

\subsubsection{Alternative B: Crush and Reuse without Decontamination}

The analysis for this alternative estimated cost and radiological doses associated with direct reuse of the concrete without decontamination. This alternative would avoid any costs for decontamination, waste packaging, transportation, or waste disposal. The radiological impacts to a construction worker associated with reuse of the concrete as roadbed material were also analyzed for this alternative.

\subsubsection{Alternative C: Decontaminate, Demolish, and Disposal at C\&D Landfill}

Costs and radiological doses associated with decontamination, demolition, and disposal of the concrete material at a nonradiological landfill were calculated for this alternative. The waste generated during decontamination would be packaged and transported to a LLW disposal facility on-site. After decontamination, the concrete material or structure would be demolished, crushed, and transported to the C\&D Landfill. Radiological doses were estimated for persons living along the transportation route for the demolished concrete material. Radiological doses were also estimated for persons working at the C\&D disposal facility. The radiation dose to a future resident living at the site after landfill closure was also estimated.

\subsubsection{Alternative D: Demolish and Disposal at C\&D Landfill}

Alternative D estimated costs and radiological impacts associated with demolishing the concrete material and transporting it to a nonradiological landfill. Radiological impacts were estimated for the driver, landfill worker, and the future resident, as in Alternative C. 


\subsubsection{Alternative E: Demolish and Disposal at a Low-Level Waste Disposal Facility}

Alternative E estimated costs and radiological impacts associated with demolition, packaging, transportation, and disposal of the concrete material at a LLW disposal facility.

\subsection{ANALYZING ALTERNATIVES}

Since characterization data for the digester, deep well at CFA-691, and 657 pumphouse were not available, those structures were not analyzed in this report. For this analysis it was assumed that the contamination may not necessarily all be on the surface, because it may have soaked into the concrete. However, since characterization data for different depths within the concrete were not available, certain assumptions regarding the contamination levels were necessary. The assumptions used in this analysis are described in the following paragraphs.

Trickle Filter: For the trickle filter it was assumed that the floor was contaminated up to 1 in. deep and the walls were contaminated to a 0.5 -in. depth. Scans on the interior trickler walls were all $<1,000 \mathrm{dpm} / 100 \mathrm{~cm}^{2}$ beta/gamma and $<20 \mathrm{dpm} / 100 \mathrm{~cm}^{2}$ alpha. All smears were $<1,000 \mathrm{dpm} / 100 \mathrm{~cm}^{2}$ beta/gamma and $<20 \mathrm{dpm} / 100 \mathrm{~cm}^{2}$ alpha. However, contamination in the range of $1,200-9,600 \mathrm{dpm} / 100 \mathrm{~cm}^{2}$ was found on the interior of the trickler column and trickler arms. It was assumed that, after decontamination, the concrete was still uniformly contaminated at $1 / 10$ of the initial levels.

Primary Clarifier: For the primary clarifier it was assumed that sewage had contaminated the floor to a depth of $2 \mathrm{in}$. and the walls to a depth of $1 \mathrm{in}$. Since characterization data at different wall levels or floor areas were not available, it was assumed the contamination had spread throughout the whole area. During characterization, spots of fixed contamination were identified on interior walls of the primary clarifier. Levels ranged from 1,200 to $25,000 \mathrm{dpm} / 100 \mathrm{~cm}^{2}$. It was assumed that decontaminated concrete was still uniformly contaminated at $1 / 10$ of the initial contamination levels.

Secondary Clarifier: Results of the radiological survey for the secondary clarifier, presented in units of $\mathrm{pCi} / \mathrm{L}$, were converted to $\mathrm{pCi} / \mathrm{g}$, and these values were assumed to be the radionuclide contamination of the concrete. Since only a small amount of waste was generated during decontamination activities of the CFA-691 pumphouse $\left(3 \mathrm{ft}^{3}\right)$, the entire amount of generated waste came from the secondary clarifier. It was assumed that decontaminated concrete was still uniformly contaminated at $1 / 10$ of the initial contamination levels.

CFA-691 Pumphouse: It was assumed that the pumphouse floor was contaminated up to a depth of 1 in., and walls were contaminated to a depth of 0.5 in. It was assumed that decontaminated concrete was still uniformly contaminated at $1 / 10$ of the initial contamination levels. 
The technologies used for removing fixed subsurface contamination from concrete were automated floor and wall scabbling. Table 3 gives the capital cost, production rate, process cost, and removal rate used in both the generic and INEEL-specific calculations.

\subsubsection{Cost Analysis}

Tables $4 \mathrm{a}$ (generic) and 4b (INEEL-specific) present the results of the cost analysis for the alternatives considered for disposition of concrete from this D\&D project. The cost elements for each alternative are summarized below:

Total Cost for Alternative $\boldsymbol{A}=\mathrm{D} \& \mathrm{D}$ cost + disposal cost of LLW generated from D\&D + shipment and packaging cost of LLW generated + demolishing and crushing cost of decontaminated concrete + management cost.

Total Cost for Alternative $\boldsymbol{B}=$ Demolishing and crushing cost of the concrete + management cost.

Total Cost for Alternative $C=\mathrm{D} \& \mathrm{D}$ cost + disposal cost of LLW generated from D\&D + shipment and packaging cost of LLW generated + demolishing and crushing cost of decontaminated concrete + shipment cost of $C \& D+$ disposal to $C \& D$ landfill of rest of the concrete + management cost.

Total Cost for Alternative $\boldsymbol{D}=$ Demolishing and crushing cost of the concrete + shipment cost of C\&D + disposal to C\&D landfill of all the concrete removed + management cost.

Total Cost for Alternative $\boldsymbol{E}=$ Waste disposal at LLW facility + shipment cost + waste packaging cost + demolishing and crushing cost + management cost.

TABLE 3 Characteristics of Technologies Used for Removing Fixed Subsurface Concrete Contamination

\begin{tabular}{cccccc}
\hline Technology & $\begin{array}{c}\text { Purchase } \\
\operatorname{Cost}^{\mathrm{a}}(\$)\end{array}$ & $\begin{array}{c}\text { Hourly } \\
\text { Cost }(\$)\end{array}$ & $\begin{array}{c}\text { Production Rate } \\
\left(\mathrm{ft}^{2} / \mathrm{h} / \mathrm{pass}\right)\end{array}$ & $\begin{array}{c}\text { Process Cost } \\
\left(\$ / \mathrm{ft}^{2} / \mathrm{pass}\right)\end{array}$ & $\begin{array}{c}\text { Removal Rate } \\
(\mathrm{in} . / \mathrm{pass})\end{array}$ \\
\hline Automated floor scabbling & 100,000 & 50 & 200 & 5 & $1 / 2$ \\
Automated wall scabbling & 200,000 & 50 & 150 & 10 & $1 / 4$ \\
\hline
\end{tabular}

a It was assumed that the purchase cost of the equipment was the true cost to the site. In actuality, the site has bought this equipment for use in decontaminating many structures, thus reducing the cost per use or project over a period of time. 
For cost analysis, the following assumptions 3 were made (if INEEL-specific cost was different, it is also included):

- Distance to C\&D disposal facility $=20 \mathrm{mi}(\sim 40 \mathrm{~km})$ (Ayres et al. 1999).

- $\quad$ Cost to transport $\mathrm{C} \& \mathrm{D}$ waste $=\$ 0.15 / \mathrm{yd}^{3} / \mathrm{mi}($ Ayres et al. 1999).

- $\quad$ Disposal cost of C\&D waste $=\$ 25 / \mathrm{yd}^{3}$ (Ayres et al. 1999).

- Distance to LLW disposal facility $=327 \mathrm{mi}(\sim 600 \mathrm{~km})$ (distance from INEEL to Envirocare [Ayres et al. 1999]).

- $\quad$ LLW waste disposal cost $=\$ 65 / \mathrm{ft}^{3}$ (Arnish et al. 2000).

- $\quad$ Demolishing cost $=\$ 1 / \mathrm{ft}^{2}$ (Arnish et al. 2000).

- $\quad$ Concrete crushing cost $=\$ 23 / \mathrm{MT}$ (Arnish et al. 2000).

- Distance to C\&D disposal facility [INEEL-specific] $=2 \mathrm{mi}(\sim 4 \mathrm{~km})$ (INEEL personal communication 2000).

- Cost to transport C\&D waste [INEEL-specific] $=\$ 0.42 / \mathrm{yd}^{3} / \mathrm{mi}$ (INEEL personal communication 2000).

- Disposal cost of C\&D waste [INEEL-specific] $=\$ 54.5 / \mathrm{yd}^{3}$ (INEEL personal communication 2000).

- Distance to LLW disposal (INEEL-specific [RWMC]) facility $=10 \mathrm{mi}$ $(\sim 20 \mathrm{~km})$ (disposal is on-site at INEEL [INEEL personal communication, 2000]).

- LLW waste disposal cost (INEEL-specific [for disposal at RWMC) $=\$ 0 / \mathrm{ft}^{3}$ (RWMC does not charge a disposal fee for LLW for INEEL projects [INEEL personal communication 2000]).

- $\quad$ Concrete crushing cost $=\$ 10.63 / \mathrm{MT}$ (INEEL personal communication 2000).

3 For the sake of conservatism in analysis, distances originally given in miles have been rounded up when converted to kilometers. 
TABLE 4a Generic Cost Analysis for Different Alternatives Considered for Concrete Disposition

\begin{tabular}{|c|c|c|c|c|c|c|c|c|c|c|c|}
\hline \multirow[b]{2}{*}{ Structure } & \multirow[b]{2}{*}{ Alternative } & \multicolumn{10}{|c|}{ Estimated Costs $(\$)$} \\
\hline & & Decon & Demolishing & Crushing & Packaging & $\begin{array}{c}\text { Waste } \\
\text { Shipment }\end{array}$ & $\begin{array}{c}\text { C\&D } \\
\text { Shipment }\end{array}$ & $\begin{array}{c}\text { LLW } \\
\text { Disposal }\end{array}$ & $\begin{array}{c}\text { C\&D } \\
\text { Disposal }\end{array}$ & Management & Total \\
\hline \multirow[t]{5}{*}{ Trickle Filter } & A & 34,718 & 3,245 & 1,964 & 2,200 & 803 & 0 & 12,367 & 0 & 10,000 & 65,296 \\
\hline & B & 0 & 3,245 & 2,239 & 0 & 0 & 0 & 0 & 0 & 10,000 & 15,484 \\
\hline & $\mathrm{C}$ & 34,718 & 3,245 & 0 & 2,200 & 803 & 151 & 12,367 & 1,255 & 10,000 & 64,739 \\
\hline & D & 0 & 3,245 & 0 & 0 & 0 & 172 & 0 & 1,431 & 10,000 & 14,848 \\
\hline & $\mathrm{E}$ & 0 & 3,245 & 0 & 25,482 & 4,816 & 0 & 100,490 & 0 & 10,000 & 144,033 \\
\hline \multirow{5}{*}{ Primary Clarifier } & A & 47,731 & 1,356 & 1,159 & 1,900 & 803 & 0 & 9,797 & 0 & 10,000 & 72,746 \\
\hline & B & 0 & 1,356 & 1,377 & 0 & 0 & 0 & 0 & 0 & 10,000 & 12,734 \\
\hline & $\mathrm{C}$ & 47,731 & 1,356 & 0 & 1,900 & 803 & 89 & 9,797 & 741 & 10,000 & 72,417 \\
\hline & $\mathrm{D}$ & 0 & 1,356 & 0 & 0 & 0 & 106 & 0 & 881 & 10,000 & 12,343 \\
\hline & $\mathrm{E}$ & 0 & 1,356 & 0 & 15.675 & 3,210 & 0 & 61,815 & 0 & 10,000 & 92,057 \\
\hline \multirow[t]{5}{*}{ Secondary Clarifier } & A & 2,660 & 1,356 & 1,350 & 450 & 2,188 & 0 & 1,225 & 0 & 10,000 & 19,229 \\
\hline & B & 0 & 1,356 & 1,377 & 0 & 0 & 0 & 0 & 0 & 10,000 & 12,734 \\
\hline & C & 2,660 & 1,356 & 0 & 450 & 2,188 & 104 & 1,225 & 863 & 10,000 & 18,846 \\
\hline & D & 0 & 1,356 & 0 & 0 & 0 & 106 & 0 & 881 & 10,000 & 12,343 \\
\hline & $\mathrm{E}$ & 0 & 1,356 & 0 & 17,100 & 3,210 & & 61,815 & 0 & 10,000 & 93,482 \\
\hline \multirow[t]{5}{*}{ CFA-691 Pumphouse } & A & 50,990 & 3,384 & 1,932 & 3,453 & 2,188 & 0 & 10,473 & 0 & 10,000 & 82,420 \\
\hline & B & 0 & 3,384 & 2,165 & 0 & 0 & 0 & 0 & 0 & 10,000 & 15,549 \\
\hline & $\mathrm{C}$ & 50,990 & 3,384 & 0 & 3,453 & 2,188 & 148 & 10,473 & 1,235 & 10,000 & 81,872 \\
\hline & D & 0 & 3,384 & 0 & 0 & 0 & 166 & 0 & 1,384 & 10,000 & 14,934 \\
\hline & $\mathrm{E}$ & 0 & 3,384 & 0 & 24,641 & 4,816 & 0 & 97,175 & 0 & 10,000 & 140,016 \\
\hline
\end{tabular}


TABLE 4b INEEL-Specific Cost Analysis for Different Alternatives Considered for Concrete Disposition

\begin{tabular}{|c|c|c|c|c|c|c|c|c|c|c|c|}
\hline \multirow[b]{2}{*}{ Structure } & \multirow[b]{2}{*}{ Alternative } & \multicolumn{10}{|c|}{ Estimated Cost $(\$)$} \\
\hline & & Decon & Demolishing & Crushing & Packaging & $\begin{array}{c}\text { Waste } \\
\text { Shipment }\end{array}$ & $\begin{array}{c}\text { C\&D } \\
\text { Shipment } \\
\end{array}$ & $\begin{array}{c}\text { LLW } \\
\text { Disposal } \\
\end{array}$ & $\begin{array}{c}\text { C\&D } \\
\text { Disposal } \\
\end{array}$ & Management & Total \\
\hline \multirow[t]{5}{*}{ Trickle Filter } & A & 34,718 & 3,245 & 854 & 2,200 & 349 & 0 & 0 & 0 & 10,000 & 51,366 \\
\hline & B & 0 & 3,245 & 1,035 & 0 & 0 & 0 & 0 & $\mathbf{0}$ & 10,000 & 14,280 \\
\hline & $\mathrm{C}$ & 34,718 & 3,245 & 0 & 2,200 & 349 & 42 & 0 & 2,727 & 10,000 & 53,281 \\
\hline & $\mathrm{D}$ & 0 & 3,245 & 0 & 0 & 0 & 48 & 0 & 3,109 & 10,000 & 16,402 \\
\hline & $\mathrm{E}$ & 0 & 3,245 & $\mathbf{0}$ & 25,482 & 2,096 & 0 & 0 & 0 & 10,000 & 40,823 \\
\hline \multirow[t]{5}{*}{ Primary Clarifier } & A & 47,731 & 1,356 & 504 & 1,900 & 349 & 0 & 0 & 0 & 10,000 & 61,841 \\
\hline & B & 0 & 1,356 & 637 & 0 & 0 & 0 & 0 & 0 & 10,000 & 11,993 \\
\hline & $\mathrm{C}$ & 47,731 & 1,356 & 0 & 1,900 & 349 & 25 & 0 & 1,609 & 10,000 & 63,075 \\
\hline & $\mathrm{D}$ & 0 & 1,356 & $\mathbf{0}$ & 0 & 0 & 30 & 0 & 1,913 & 10,000 & 13,299 \\
\hline & $\mathrm{E}$ & $\mathbf{0}$ & 1,356 & $\mathbf{0}$ & 15,675 & 1,397 & 0 & 0 & 0 & 10,000 & 28,429 \\
\hline \multirow[t]{5}{*}{ Secondary Clarifier } & A & 2,660 & 1,356 & 624 & 450 & 920 & 0 & 0 & 0 & 10,000 & 16,010 \\
\hline & B & 0 & 1,356 & 637 & 0 & 0 & 0 & 0 & 0 & 10,000 & 11,993 \\
\hline & $\mathrm{C}$ & 2,660 & 1,356 & 0 & 450 & 920 & 29 & 0 & 1,875 & 10,000 & 17,290 \\
\hline & $\mathrm{D}$ & 0 & 1,356 & 0 & $\mathbf{0}$ & 0 & 30 & 0 & 1,913 & 10,000 & 13,299 \\
\hline & $\mathbf{E}$ & 0 & 1,356 & 0 & 17,100 & 1,397 & 0 & 0 & 0 & 10,000 & 29,854 \\
\hline \multirow[t]{5}{*}{ CFA-691 Pumphouse } & A & 50,990 & 3,384 & 840 & 3,453 & 920 & 0 & 0 & 0 & 10,000 & 69,587 \\
\hline & B & 0 & 3,384 & 1,001 & 0 & 0 & 0 & 0 & 0 & 10,000 & 14,385 \\
\hline & $\mathrm{C}$ & 50,990 & 3,384 & 0 & 3,453 & 920 & 41 & 0 & 2,683 & 10,000 & 71,471 \\
\hline & $\mathrm{D}$ & 0 & 3,384 & 0 & 0 & 0 & 47 & 0 & 3,007 & 10,000 & 16,437 \\
\hline & $\mathrm{E}$ & 0 & 3,384 & 0 & 24,641 & 2,096 & 0 & 0 & 0 & 10,000 & 40,121 \\
\hline
\end{tabular}


- Waste packaging cost from equation 3.15 of Arnish et al. (2000).

- LLW waste shipment cost from equation 3.16 of Arnish et al. (2000).

- D\&D cost from equation 3.7 of Arnish et al. (2000).

- The $\mathrm{D} \& \mathrm{D}$ equipment lifetime $=10$ years; interest rate $=8 \%$; equipment use time for each D\&D operation $=1$ week (168 hours).

- $\quad$ Management cost for all alternatives $=\$ 10,000$.

- Concrete density $=2.2 \mathrm{~g} / \mathrm{cm}^{3}$, which results in $1 \mathrm{ft}^{3}=0.06297 \mathrm{MT}$.

\subsubsection{Radiological Dose Analysis}

Radiological dose analysis unit dose factors from Arnish et al. (2000) were used with the characterization data to calculate the radiological impacts for the different disposal alternatives. It was assumed that even after decontamination, concrete would still be contaminated at 1/10 of the initial contamination level (Table 2). Worker doses were estimated for nonradiation workers, and population doses were estimated if the material was sent off-site.

Impacts to the following receptors were determined for the various alternatives:

- Alternative A: Population along the LLW driving corridor (not analyzed for INEEL specific case) and the construction worker.

- Alternative B: Construction worker.

- Alternative C: Population along the LLW (not analyzed for INEEL-specific case) and C\&D driving corridors, driver dose for C\&D waste, landfill worker at C\&D waste disposal facility, and the future resident at C\&D facility after facility closure.

- Alternative D: Population along the C\&D driving corridor, driver dose for $\mathrm{C} \& \mathrm{D}$ waste, landfill worker at C\&D waste disposal facility, and the future resident at C\&D facility after facility closure.

- Alternative E (generic case): Population along the LLW driving corridor. 
- Alternative E (INEEL-specific case): None analyzed, because waste does not leave INEEL boundary.

Tables 5a (generic case) and 5b (INEEL-specific case) summarize the radiological impacts for the different alternatives.

\subsection{RESULTS AND CONCLUSIONS}

DOE's authorized release process requires that no action should result in individual doses to a member of the public in excess of the primary dose limit of $100 \mathrm{mrem}$ total effective dose equivalent in one year (DOE Order 5400.5). Because the primary dose limit is for all sources, a dose constraint from only DOE sources of one quarter of the primary dose limit (i.e., $25 \mathrm{mrem} / \mathrm{yr}$ ) is used.

DOE also requires that all releases and exposures to the public be controlled to ensure that they are maintained to levels that are as low as is reasonably achievable (ALARA) below the applicable dose limits. Releases are to be assessed in a manner consistent with the DOE ALARA process for protection of the public and environment (DOE 1997). Thus, authorized limits for annual dose from the release of concrete should be as far below 25 mrem as is practicable. The dose constraint of $25 \mathrm{mrem} / \mathrm{yr}$ represents an upper bound or "cap" for ALARA-based authorized limits for release of concrete containing residual radioactive material. Therefore, an ALARA analysis was conducted in the assessment of potential release options to support the final authorized release option selected for the concrete release. It is DOE's goal to establish release limits that would control exposures such that anticipated doses to members of the public are reduced to a few $\mathrm{mrem} / \mathrm{yr}$ or less above background.

Authorized limits may be derived and approved by DOE Field Office managers without EH-1 approval if certain conditions are met (Arnish et al. 2000). One of those conditions is that the release of the concrete material will not cause a maximum individual dose to a member of the public in excess of $1 \mathrm{mrem}$ in a year or a collective dose of more than 10 person-rem in a year.

Tables 5a (generic case) and 5b (INEEL-specific case) summarize the costs and radiological impacts associated with different alternatives for the STP concrete. Those results indicate that Alternative B or D would incur the lowest cost and would result in a dose much less than $25 \mathrm{mrem}$. With the exception of the trickle structure, each of those alternatives would result in a dose less than 1 mrem for the nonradiological workers. In addition, these two alternatives are estimated to incur the lowest total costs. However, if the concrete cannot be reused on-site, decontaminated concrete can be free released for disposal at a construction and debris landfill. It should be noted that the main contribution to the radiological doses would be from Co-60 (half 
TABLE 5A Generic Summary of Cost and Radiological Impacts for Different Alternatives

\begin{tabular}{|c|c|c|c|c|c|c|}
\hline \multirow[b]{2}{*}{ Structure } & \multirow[b]{2}{*}{ Alternative } & \multirow[b]{2}{*}{$\begin{array}{c}\text { Total } \\
\text { Costs }(\$)\end{array}$} & \multicolumn{4}{|c|}{ Dose } \\
\hline & & & $\begin{array}{l}\text { Driver } \\
(\mathrm{mrem})\end{array}$ & $\begin{array}{l}\text { Population } \\
\text { (person-rem) }\end{array}$ & $\begin{array}{l}\text { Worker } \\
\text { (mrem) }\end{array}$ & $\begin{array}{l}\text { Future } \\
\text { Resident } \\
\text { (mrem) }\end{array}$ \\
\hline \multirow[t]{5}{*}{ Trickle Filter } & A & 65,296 & None & $1.90 \times 10^{-4}$ & $8.000 \times 10^{-1}$ & None \\
\hline & $\mathrm{B}$ & 15,484 & None & None & 1.92 & None \\
\hline & $\mathrm{C}$ & 64,739 & $2.86 \times 10^{-2}$ & $1.99 \times 10^{-4}$ & $1.49 \times 10^{-2}$ & 1.47 \\
\hline & $\mathrm{D}$ & 14,848 & $6.87 \times 10^{-2}$ & $2.17 \times 10^{-5}$ & $3.58 \times 10^{-2}$ & 3.53 \\
\hline & $\mathrm{E}$ & 144,033 & None & $3.25 \times 10^{-4}$ & None & None \\
\hline \multirow[t]{5}{*}{ Primary Clarifier } & A & 72,746 & None & $1.14 \times 10^{-5}$ & $8.42 \times 10^{-2}$ & None \\
\hline & $\mathrm{B}$ & 12,734 & None & None & $2.17 \times 10^{-1}$ & None \\
\hline & $\mathrm{C}$ & 72,417 & $1.28 \times 10^{-3}$ & $1.18 \times 10^{-5}$ & $9.14 \times 10^{-4}$ & $2.17 \times 10^{-1}$ \\
\hline & $\mathrm{D}$ & 12,343 & $3.70 \times 10^{-3}$ & $1.16 \times 10^{-6}$ & $2.64 \times 10^{-3}$ & $6.27 \times 10^{-1}$ \\
\hline & $\mathrm{E}$ & 92,057 & None & $1.75 \times 10^{-5}$ & None & None \\
\hline \multirow[t]{5}{*}{ Secondary Clarifier } & A & 19,229 & None & $3.83 \times 10^{-11}$ & $1.64 \times 10^{-5}$ & None \\
\hline & $\mathrm{B}$ & 12,734 & None & None & $1.69 \times 10^{-5}$ & None \\
\hline & $\mathrm{C}$ & 18,846 & $4.01 \times 10^{-7}$ & $1.64 \times 10^{-10}$ & $5.31 \times 10^{-7}$ & $4.25 \times 10^{-5}$ \\
\hline & $\mathrm{D}$ & 12,343 & $4.21 \times 10^{-7}$ & $1.32 \times 10^{-10}$ & $5.58 \times 10^{-7}$ & $4.39 \times 10^{-5}$ \\
\hline & $\mathrm{E}$ & 93,482 & None & $1.98 \times 10^{-9}$ & None & None \\
\hline \multirow[t]{5}{*}{ CFA-691 Pumphouse } & $\mathrm{A}$ & 82,420 & None & $1.37 \times 10^{-6}$ & $1.2 \times 10^{-1}$ & None \\
\hline & B & 15,549 & None & None & $2.5 \times 10^{-1}$ & None \\
\hline & $\mathrm{C}$ & 81,872 & $2.70 \times 10^{-3}$ & $2.22 \times 10^{-6}$ & $1.61 \times 10^{-3}$ & $3.65 \times 10^{-1}$ \\
\hline & $\mathrm{D}$ & 14,934 & $5.67 \times 10^{-3}$ & $1.79 \times 10^{-6}$ & $3.39 \times 10^{-3}$ & $7.68 \times 10^{-1}$ \\
\hline & $\mathrm{E}$ & 140,016 & None & $2.68 \times 10^{-5}$ & None & None \\
\hline
\end{tabular}

life of 5.27 years). 4 Since the characterization conducted in 1996 was the starting point for this analysis, some of the short-lived radionuclides, such as Co-60, would have decayed to $60 \%$ of their initial levels in 4 years. The resultant doses to receptors now or later would be much less than the values reported in this analysis. This analysis also demonstrates that reuse or free release of the concrete without decontamination would result in doses greater than $1 \mathrm{mrem} / \mathrm{yr}$ to the future resident at the $\mathrm{C} \& \mathrm{D}$ landfill.

4 The INEEL selected disposition Alternative C (decontaminate, demolish, and disposal at a nonradiological landfill) for trickle filter and primary clarifier structures and Alternative D (demolish and disposal at a nonradiological landfill) for secondary clarifier and CFA-691 pumphouse. 
TABLE 5b INEEL-Specific Summary of Cost and Radiological Impacts for Different Alternatives

\begin{tabular}{|c|c|c|c|c|c|c|}
\hline \multirow[b]{2}{*}{ Structure } & \multirow[b]{2}{*}{ Alternative } & \multirow[b]{2}{*}{$\begin{array}{c}\text { Total } \\
\text { Costs }(\$)\end{array}$} & \multicolumn{4}{|c|}{ Dose } \\
\hline & & & $\begin{array}{l}\text { Driver } \\
(\mathrm{mrem})\end{array}$ & $\begin{array}{l}\text { Population } \\
\text { (person-rem) }\end{array}$ & $\begin{array}{l}\text { Worker } \\
(\mathrm{mrem})\end{array}$ & $\begin{array}{l}\text { Future } \\
\text { Resident } \\
\text { (mrem) }\end{array}$ \\
\hline \multirow[t]{5}{*}{ Trickle Filter } & A & 51,366 & None & $6.33 \times 10^{-6}$ & $8.00 \times 10^{-1}$ & None \\
\hline & $\mathrm{B}$ & 14,280 & None & None & 1.92 & None \\
\hline & $\mathrm{C}$ & 53,281 & $2.86 \times 10^{-3}$ & $9.01 \times 10^{-7}$ & $1.49 \times 10^{-2}$ & 1.47 \\
\hline & $\mathrm{D}$ & 16,402 & $6.87 \times 10^{-3}$ & $2.17 \times 10^{-6}$ & $3.58 \times 10^{-2}$ & 3.53 \\
\hline & $\mathrm{E}$ & 40,823 & None & None & None & None \\
\hline \multirow[t]{5}{*}{ Primary Clarifier } & $\mathrm{A}$ & 61,841 & None & $3.80 \times 10^{-7}$ & $8.42 \times 10^{-2}$ & None \\
\hline & $\mathrm{B}$ & 11,993 & None & None & $2.17 \times 10^{-1}$ & None \\
\hline & $\mathrm{C}$ & 63,075 & $1.28 \times 10^{-4}$ & $4.21 \times 10^{-7}$ & $9.14 \times 10^{-4}$ & $2.17 \times 10^{-1}$ \\
\hline & $\mathrm{D}$ & 13,299 & $3.70 \times 10^{-4}$ & $1.16 \times 10^{-7}$ & $2.64 \times 10^{-3}$ & $6.27 \times 10^{-1}$ \\
\hline & $\mathrm{E}$ & 28,429 & None & None & None & None \\
\hline \multirow[t]{5}{*}{ Secondary Clarifier } & A & 16,010 & None & $1.28 \times 10^{-12}$ & $1.64 \times 10^{-5}$ & None \\
\hline & $\mathrm{B}$ & 11,993 & None & None & $1.69 \times 10^{-5}$ & None \\
\hline & $\mathrm{C}$ & 17,290 & $4.01 \times 10^{-8}$ & $1.39 \times 10^{-11}$ & $5.31 \times 10^{-7}$ & $4.25 \times 10^{-5}$ \\
\hline & $\mathrm{D}$ & 13,299 & $4.21 \times 10^{-8}$ & $1.32 \times 10^{-11}$ & $5.58 \times 10^{-7}$ & $4.39 \times 10^{-5}$ \\
\hline & $\mathrm{E}$ & 29,854 & None & None & None & None \\
\hline \multirow[t]{5}{*}{ CFA-691 Pumphouse } & A & 69,587 & None & $4.57 \times 10^{-8}$ & $1.20 \times 10^{-1}$ & None \\
\hline & B & 14,385 & None & None & $2.50 \times 10^{-1}$ & None \\
\hline & $\mathrm{C}$ & 71,471 & $2.70 \times 10^{-4}$ & $1.31 \times 10^{-7}$ & $1.61 \times 10^{-3}$ & $3.65 \times 10^{-1}$ \\
\hline & $\mathrm{D}$ & 16,437 & $5.67 \times 10^{-4}$ & $1.79 \times 10^{-7}$ & $3.39 \times 10^{-3}$ & $7.68 \times 10^{-1}$ \\
\hline & $\mathrm{E}$ & 40,121 & None & None & None & None \\
\hline
\end{tabular}




\section{REFERENCES}

Arnish, J., et al., 2000, Protocol for Development of Authorized Release Limits for Concrete at U.S. Department of Energy Sites, ANL/EAD/TM-92, Argonne National Laboratory, Argonne, Ill., July.

Ayres, K.W., et al., 1999, Reuse of Concrete from Contaminated Structures, Department of Civil and Environmental Engineering, Vanderbilt University, Nashville, Tenn., Jan.

Klassy, C.E., and A.F. Brown, 1997, D\&D Characterization and Decision Analysis Report for the Central Facilities Area Sewage Treatment Plant, INEL-96/0360, Rev. 0, Idaho National Engineering and Environmental Laboratory, Idaho Falls, Idaho, June.

Thiel, T.N., and J.L. Allen, 1998, Decontamination and Decommissioning Plan for the Central Facility Sewage Treatment Plant, INEEL/EXT-98-00018, Revision 0, Idaho National Engineering and Environmental Laboratory, Idaho Falls, Idaho, Feb.

Thiel, T.N., 2000, Final D\&D Report for the Central Facilities Sewage Treatment Plant, Idaho National Engineering and Environmental Laboratory, Idaho Falls, Idaho.

U.S. Department of Energy, 1997, Draft Handbook for Controlling Release for Reuse or Recycle of Property Containing Residual Radioactive Material, Interim Guide for Interim Use and Comment, Washington, D.C., June. 


\author{
APPENDIX A: \\ APPLICATION FOR THE DEVELOPMENT OF AUTHORIZED \\ RELEASE LIMITS FOR CONCRETE FROM \\ THE TRICKLE FILTER - GENERIC CASE
}


Application for the Development of Authorized Release Limits for Concrete

\author{
(A Sample "Walk Through" \\ for the Trickle Filter)
}




\section{Authorized Release Process}

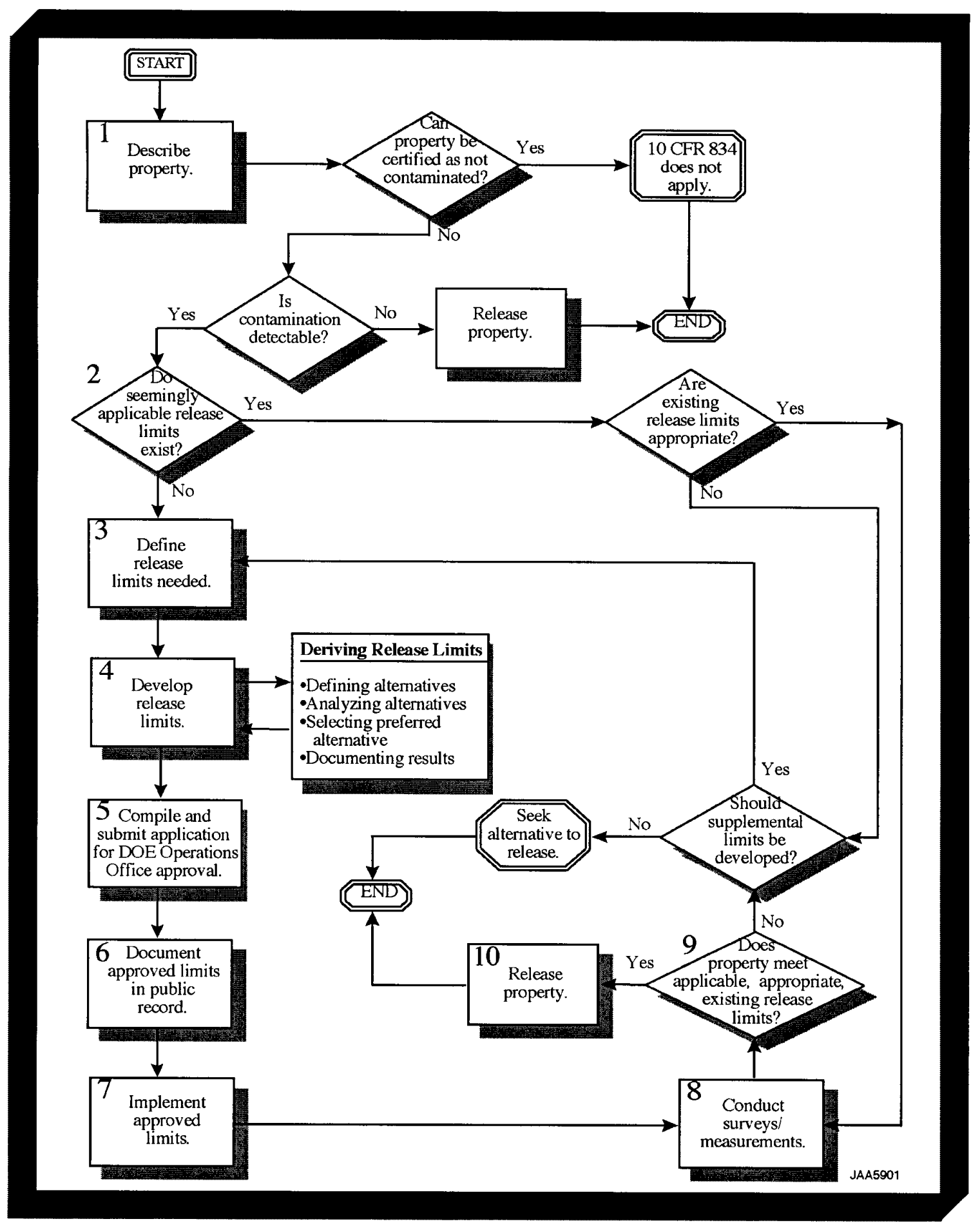




\section{Step 1. Characterize Property and Prepare a Description ( Chapter 2, Section 2.1)}

\section{(All information in the form should be typed)}

\section{1a Physical Characteristics}

Describe the physical characteristics of the concrete material (volume of material, age, location, etc.)

Volume: $1,546 \mathrm{ft}^{3}=43.778 \mathrm{~m}^{3}=97.35$ metric tons

(Trickle Filter from the Sewage Treatment Plant at Central Facilities Area 691)

This auxiliary structure was located northwest of the pumphouse. The trickle filter was a 50-ftdiameter, cylindrical-shaped concrete structure. The walls consisted of 8 -ft 2 -in. high concrete topped with $5 \mathrm{ft}$ of wood that surrounded the trickler. There was a $3 \times 4$ - $\mathrm{ft}$ door for entry into the trickler. It had a reinforced 4 -in. thick concrete slab floor with welded wire mesh. On top of the concrete slab floor was a layer of concrete filter blocks covered with rock filled material 6-ft deep.

\section{1b Radiological History}

Describe the radiological history of the concrete material (i.e., known areas of contamination, etc.)

One sediment sample was collected from inside the trickle filter arm. This was the only place any loose contamination was found. Radionuclides detected and measured in the sample were Am-241, Pu-238, Pu-239, Ra-226, U-234, U-245, U-238, Sr-90, Cs-137, Co-60, Eu-152, and Ru-103.

No contamination was picked up on the smears or large area wipes for the trickler arm pipes and columns, but removable soil and rust from the pipe read $>1000 \mathrm{dpm} / 100 \mathrm{~cm}^{2}$ beta/gamma. The direct scans from the interior and exterior walls (metal, wood siding, and concrete) of the trickle filter were $<1000 \mathrm{dpm} / 100 \mathrm{~cm}^{2}$ beta/gamma and $<20 \mathrm{dpm} / 100 \mathrm{~cm}^{2}$ alpha. 
Step 1. Characterize Property and Prepare a Description (Chapter 2, Section 2.1)

\section{1c Radiological History Questionnaire}

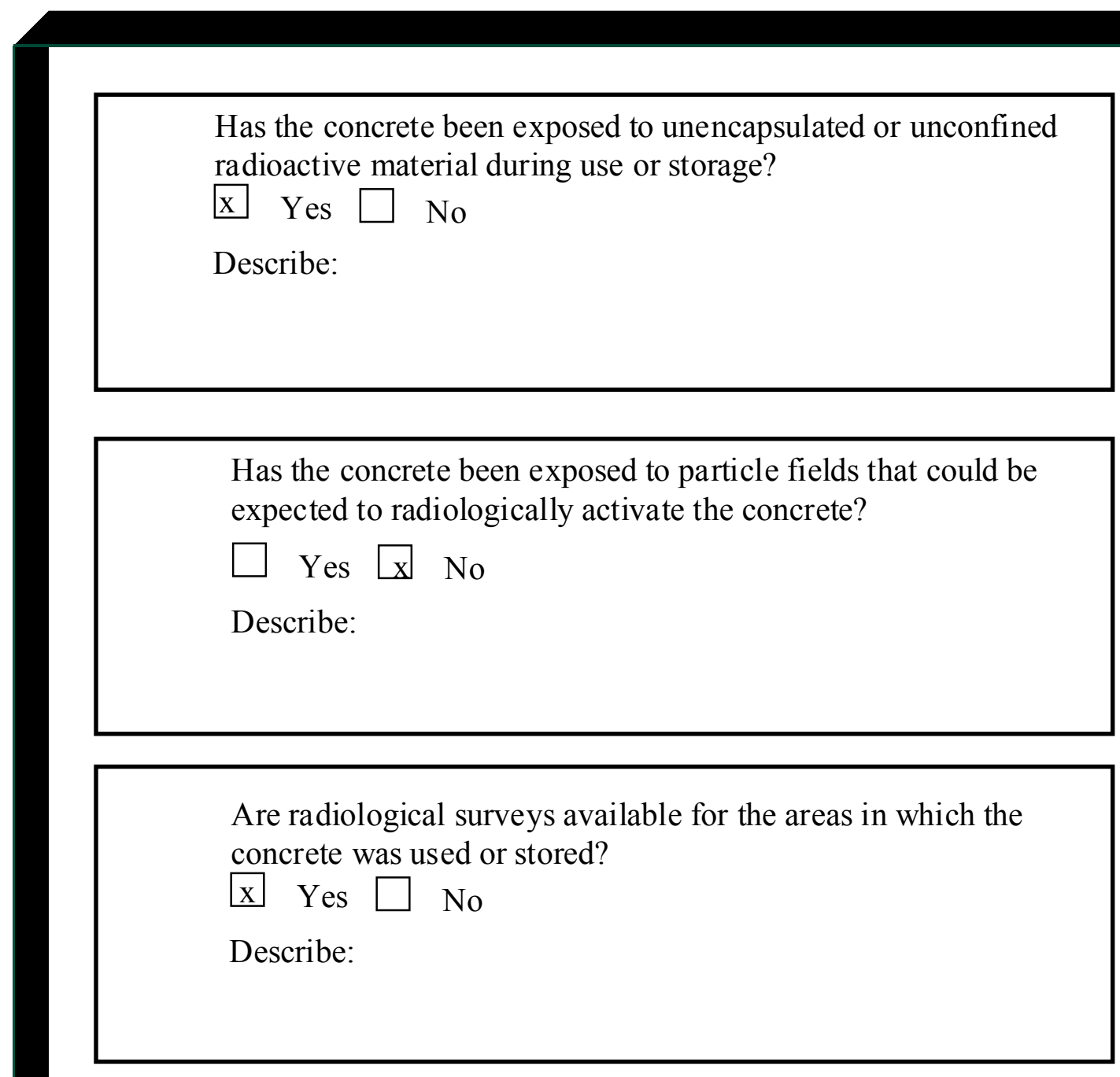

Are valid comparison data available for naturally occurring radionuclides in concrete that HAS NOT been used, stored, or exposed to transferable radioactive material?

\section{$\square$ Yes $\mathrm{X}$ No}

Describe: 


\section{Step 1. Characterize Property and Prepare a Description (Chapter 2, Section 2.1)}

1d Radiological Determination

Based on the answers provided in questions $1 \mathrm{~b}, 1 \mathrm{c}$, and $1 \mathrm{~d}$, the concrete being released is determined to be radioactive nonradioactive (circle one).

Basis for nonradioactive

Radiological history, process knowledge, and release surveys indicate contamination is unlikely (answered "no" to all questions in 1c).

Signed: Name

Date: Date

(Radiological Control Representative)

Signed: Name

Date: Date

(Facility Manager)

Check one box:

$\square \quad$ The material has been determined to be nonradioactive.

DOE Order 5400.5 and 10 CFR 834 do not apply. Release material.

$\mathrm{x}$ The material is considered to be radioactive.

Go to Step 1, box e. 


\section{Step 1. Characterize Property and Prepare a Description}

\section{(Chapter 2, Section 2.1)}

1e Results of the Radiological Survey

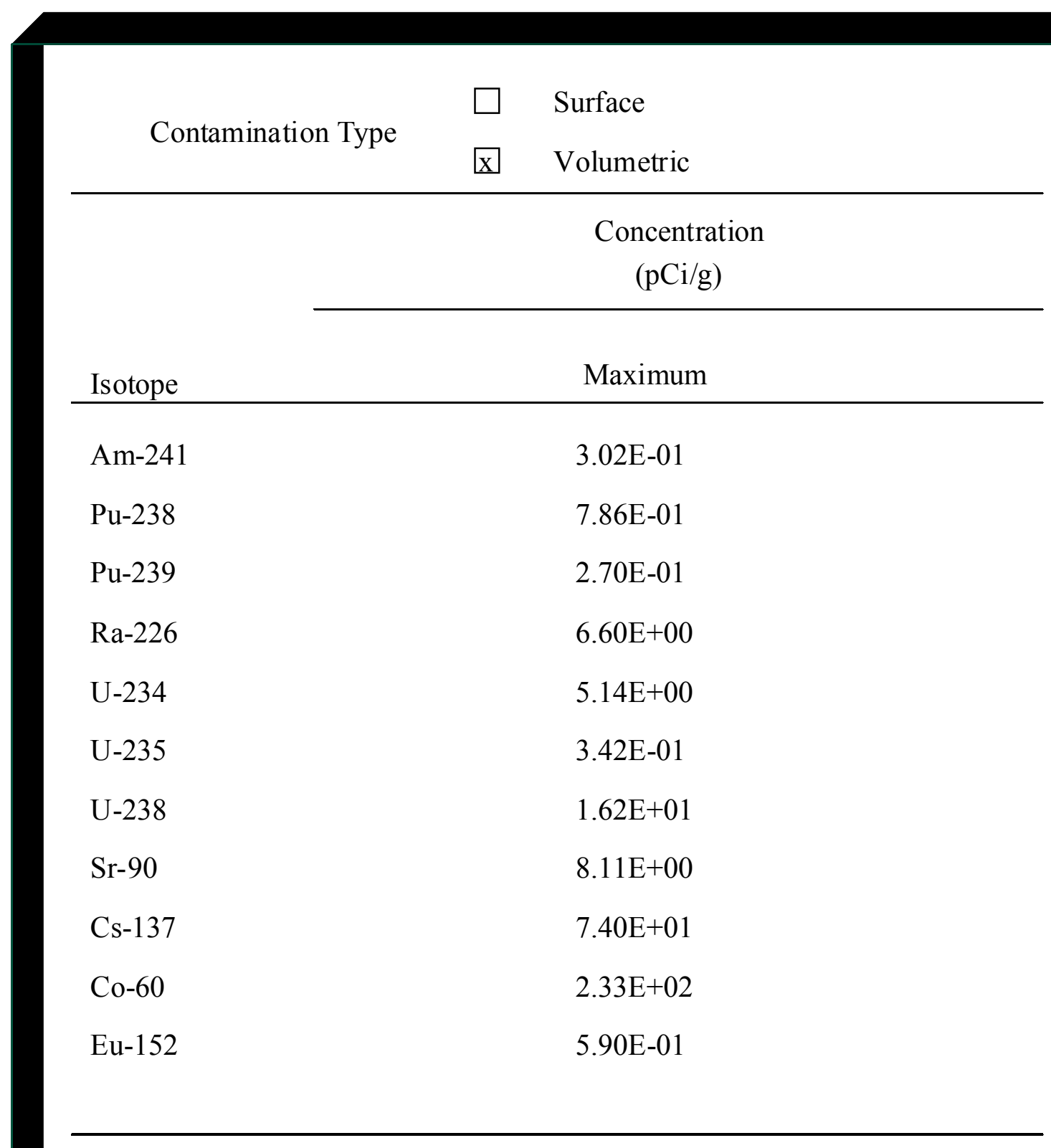




\section{Step 2. Determine Whether Applicable Authorized or Supplemental Limits Exist (Chapter 2, Section 2.2)}

2a Check for existing release limits

Check one box:

Concrete material is contaminated only on the external surfaces.

Go to Step 2, box $2 b$

$\mathrm{X}$ Concrete material is contaminated throughout the volume of the material, and authorized release limits have not been derived for a similar concrete material.

Go to Step 3, box 3a

Concrete material is contaminated throughout the volume of the material and authorized release limits have been derived for other concrete materials.

Go to Step 2, box 2d 


\section{Step 2. Determine Whether Applicable Authorized or Supplemental Limits Exist (Chapter 2, Section 2.2)}

\section{2b Surface Activity Guidelines}

\begin{tabular}{|c|c|c|c|}
\hline \multicolumn{4}{|c|}{ Allowable Total Residual Surface Activity $(\mathrm{dpm} / 100 \mathrm{sq}-\mathrm{cm})^{1}$} \\
\hline RADION U CLIDES ${ }^{2}$ & A V ER A GE $E^{3 / 4}$ & $\mathrm{M} \mathrm{AXIM} \mathrm{UM}^{4 / 5}$ & R EM O V AB LE ${ }^{2}$ \\
\hline $\begin{array}{l}\text { Group } 1-\text { Transurancics, I-125, I-129, Ac-227, Ra-226, Ra- } \\
228 \text {, Th-228, Th-230, Pa-231 }\end{array}$ & 100 & 300 & 20 \\
\hline $\begin{array}{l}\text { G roup } 2-\text { Th }- \text { natura } 1, \mathrm{~S} r-90, \mathrm{I} 26, \mathrm{I}-131, \mathrm{I}-133, \mathrm{R} \text { a- } 223, \mathrm{R} \text { a- } \\
224, \\
\mathrm{U}-232 \text {, Th-232 }\end{array}$ & 1000 & 3000 & 200 \\
\hline $\begin{array}{l}\text { Group } 3 \text { - U-natural, U-235, U-238, and associated decay } \\
\text { products, alpha emitters }\end{array}$ & 5000 & 15000 & 1000 \\
\hline $\begin{array}{l}\text { Group } 4-\text { Beta-gammaemitters (radionuclides with decay } \\
\text { modes other than alpha em ission or spontaneous fission) } \\
\text { except Sr-90 and others noted above? }\end{array}$ & 5000 & 15000 & 1000 \\
\hline Tritium (applicable to surface and subsurface $)^{8}$ & $\mathrm{~N} / \mathrm{A}$ & $\mathrm{N} / \mathrm{A}$ & 10000 \\
\hline
\end{tabular}

*Excerpt from $R$ esponse to $Q u$ estions and to $Q$ uestions and Clarification of Requirements and Processes: DOE 5400.5 , Section II. 5 and Chapter IV Implementation (Requirements Relating to Residual Radioactive material),

NOTES

'As used in this table, $d p m$ (disintegrations per $m$ in ute) means the rate of emission by radioactive material as determined by counts per minute measured by an appropriate detector for b ackground, efficiency and $\mathrm{g}$ eo $m$ etric factors associated $w$ ith the instrumentation.

${ }^{2}$ Where surface contamination by both alpha-and beta-gamma-emitting radionuclides exists, the limits established foralpha-and beta-gamma-em itting radionuclides should apply independently.

${ }^{3} \mathrm{M}$ easurements of average contamination should notbe averaged overan area of more than $1 \mathrm{sq}-\mathrm{m}$

${ }^{4}$ The average and maximum dose rates associated with surface contam ination resulting from beta-gam ma em it ters should not exceed $0.2 \mathrm{mrad} / \mathrm{h}$, and $1.0 \mathrm{mrad} / \mathrm{h}$, respectively, at $1 \mathrm{~cm}$

${ }^{5}$ The maximum contamination level applies to an area of not more than $100 \mathrm{sq}-\mathrm{cm}$

${ }^{6}$ The am ount of removable material per $100 \mathrm{sq}-\mathrm{cm}$ of surface area should be determ ined by wip ing an area of that size with dry ticer or so fl absorbent paper, applying moderate radioactive material on the wipe with an appropriate instrument of know efficiency. When removable
contamination on objects of surface arealess than $100 \mathrm{sq}$-cm is determined. The activity per unitarea should be based on the actual area and the entire surface should be wiped. It is not necessary to use wiping techniques to measure removable contamination levels if direct scan surveysindicate that the to tal residual surface contam ination levelsare with in the lim its for removable contam ination.

${ }^{7} T$ his category of radion uclides includes $m$ ix ed fission products, including the SR -90 present in them. It does not apply to $\mathrm{Sr}-90$ that has been separated from the other fission products or $m$ ixtures where the $\mathrm{Sr}-90$ has been enrich ed.

${ }^{8}$ Property recently exposed or decontaminated should have measurement (smears) at regular time intervals to ensure that there is not a build-up of contam ination over time. Because tritium typ ically penetrates $m$ aterial it contact, the surface $g$ uide lines in Group 4 are $n$ ot applicable to tritium. The Department has reviewed the Contam in ation Release Guides,"Feb.1991), and has assessed potential doses associated w ith the release of property contain ing residual tritium. The department recommends the use of the state guideline as an interim value for removable tritium. Measurements demonstrating compliance of the removable fraction of tritium on surfaces with this guideline are acceptable to ensure that nonremovable fractions and residual tritium in mass will not cause exposures that exceed DOE dose lim its and constraint.

NOTE: DOE requirements under Order 5400.5 and 10 CFR 834 allow the use of Surface Activity Guidelines (above table) as authorized release limits for residual radioactive material on surfaces only after ALARA process requirements have been met. Therefore the activity levels given in the Surface Activity Guidelines table should not be treated as existing limits until ALARA process requirements have been fulfilled. Dose estimates showing that projected doses are low should be included in documentation supporting the Surface Activity Guidelines. This may be important when the authorized limits are developed as part of a process for releasing surface contaminated concrete materials on a regular basis over a long operational period. 
Step 2. Determine Whether Applicable Authorized or Supplemental limits Exist (Chapter 2, Section 2.2)

2c-1 Are the Surface Activity Guidelines Appropriate?

Document Number

Estimated Dose Based on the Surface Activity Guidelines

\begin{tabular}{lcll}
\hline & & Measured & \\
& Dose $/\left(\mathrm{dpm} / 100 \mathrm{~cm}^{2}\right)$ & Concentration & Dose \\
Isotope & {$\left[\mathrm{mrem} /\left(\mathrm{dpm} / 100 \mathrm{~cm}^{2}\right)\right]$} & $\left(\mathrm{dpm} / 100 \mathrm{~cm}^{2}\right)$ & $(\mathrm{mrem})$ \\
\hline
\end{tabular}

Line 2c-1 Total (Sum doses from all isotopes) 


\section{Step 2. Determine Whether Applicable Authorized or Supplemental Limits Exist (Chapter 2, Section 2.2)}

2c-2 Are the Surface Activity Guidelines Appropriate?

Write Total (Line 2c.1) from the previous page mrem

Check one box:

Line $2 c-2$ is less than or equal to 1 mrem and the concentrations provided in $\mathbf{1 e}$ are less than those provided in $\mathbf{2} \mathbf{b}$.

See Chaper 2, Sections 2.8, 2.9, and 2.10

Line $2 \mathrm{c}-2$ is greater than 1 mrem or an ALARA analysis has not been previously conducted.

Go to Step 3, box 3a 
Step 2. Determine Whether Applicable Authorized or Supplemental Limits Exist (Chapter 2, Section 2.2)

2d Previously Derived Authorized or Supplemental Release Limits (If none exist go to Step 3)

Document Number

Enter the authorized release limit for each isotope

Concentration (pCi/g)

Isotope

Maximum

Average

Go to Next Page 


\section{Step 2. Determine Whether Applicable Authorized or} Supplemental Limits Exist (Chapter 2, Section 2.2)

2e Are the Existing Authorized Release Limits Appropriate?

Check one box:

The concentrations of the isotopes reported in 1e are less than or equal to the authorized release limits reported in $\mathbf{2 d}$.

See Chapter 2, Sections 2.8, 2.9, and 2.10

The concentrations of the isotopes reported in $\mathbf{1 e}$ are greater than the authorized release limits reported in $\mathbf{2 d}$; or there are isotopes listed in 1e that are not included in $\mathbf{2 d}$.

Go to Next Page 


\section{Step 3. Define Release Limits Needed (Chapter 2, Section 2.3)}

3a Release Limit Applicability

Release limits will be based on (check all that apply)

$\square$ Surface Contamination (DPM $/ 100 \mathrm{~cm}^{2}$ )

v Volumetric Contamination ( $\mathrm{pCi} / \mathrm{g}$ )

$\nabla$ One-time release

$\square \quad$ Routine release 


\section{Step 4. Develop Release Limits (Chapter 2, Section 2.4)}

\section{4a Primary ALARA Alternatives}

Check alternatives considered for ALARA analysis

$\mathrm{X}$ A. Decontaminate the concrete material, dispose of all lowlevel waste (LLW), and crush and reuse the decontaminated material

B $\quad$ B. Crush and reuse the concrete without decontamination

口 C. Decontaminate the concrete, dispose of all LLW, demolish the structure, and dispose of the decontaminated material as construction debris (nonradiological landfill) or reuse as backfill

$\mathrm{x} \quad$ D. Demolish the structure, and dispose of the concrete material as construction debris (nonradiological landfill no decontamination) or reuse as backfill

E E. Demolish the structure and dispose of all materials as LLW

F. Decontaminate the building and reuse as office space

G. Demolish the building and entomb on-site

\section{4b Secondary ALARA Alternatives}

Indicate the letter of the primary alternative, then the number of the secondary alternative considered (e.g., A1, A2, etc.). 


\section{Step 4. Develop Release Limits (Chapter 2 Section 2.4.1)}

\section{Alternative A}

Decontaminate the concrete material, dispose of all low-level waste (LLW), and crush and reuse the decontaminated material

A_a

\section{Decontamination Method(s)}

\begin{tabular}{lccc}
\hline $\begin{array}{c}\text { Decontamination } \\
\text { Method }\end{array}$ & $\begin{array}{c}\text { Decontamination } \\
\text { Factor }\end{array}$ & $\begin{array}{c}\text { Waste Generation } \\
\left(\mathrm{ft}^{3}\right)\end{array}$ & $\begin{array}{c}\text { Cost } \\
(\$)\end{array}$ \\
\hline $\begin{array}{l}\text { Automated floor and wall } \\
\text { scabbling for floor and wall } \\
\text { contamination, respectively. }\end{array}$ & 0.1 & 190.3 & 34,718 \\
\hline Total & & \\
\hline
\end{tabular}

A_b

Operational Costs

\begin{tabular}{lc}
\hline \multicolumn{1}{c}{ Operation } & $\begin{array}{c}\text { Cost } \\
(\$)\end{array}$ \\
\hline Crush Concrete & 1,964 \\
Management Costs & 10,000 \\
Other Costs $\quad \begin{array}{l}\text { (demolishing +waste } \\
\text { packaging and disposal) }\end{array}$ & $3,245+2,200+12,367$ \\
\hline Total & $\$ 29,776$ \\
\hline
\end{tabular}




\section{Step 4. Develop Release Limits (Chapter 2, Section 2.4.1)}

\section{Alternative A (Cont.)}

Decontaminate the concrete material, dispose of all low-level waste (LLW), and crush and reuse the decontaminated material

A_c

\section{Transportation Costs}

\begin{tabular}{lcccc}
\hline \multicolumn{1}{c}{ Origin } & Destination & \# of Shipments & $\begin{array}{c}\text { Distance } \\
(\mathrm{km})\end{array}$ & Cost (\$) \\
\hline $\begin{array}{l}\text { Trickle filter } \\
\begin{array}{l}\text { DECON waste } \\
\text { (contaminated concrete) }\end{array}\end{array}$ & Envirocare & 1 & 600 & 803 \\
\hline Total & & & \\
\hline
\end{tabular}

$A_{-} d$

Transportation Impacts

\begin{tabular}{|c|c|c|c|}
\hline Destination & \# of Shipments & $\begin{array}{c}\text { Distance } \\
(\mathrm{km})\end{array}$ & $\begin{array}{c}\text { Dose } \\
\text { (person-rem) }\end{array}$ \\
\hline $\begin{array}{l}\text { Trickle filter } \\
\text { secondary waste } \\
\text { (contaminated concrete) }\end{array}$ & 1 & $600 \mathrm{~km}$ & $1.9 \mathrm{E}-04$ \\
\hline Total & & & $1.9 \mathrm{E}-04$ \\
\hline
\end{tabular}




\section{Step 4. Develop Release Limits (Chapter 2, Section 2.4.1)}

\section{Alternative A (Cont.)}

Decontaminate the concrete material, dispose of all low-level waste (LLW), and crush and reuse the decontaminated material

$$
\text { A_e }
$$

Concrete Reuse-Impacts to a Construction Worker

\begin{tabular}{|c|c|c|}
\hline \multirow[b]{2}{*}{ Isotope } & $\begin{array}{l}\text { Concentration } \\
\quad(\mathrm{pCi} / \mathrm{g})\end{array}$ & Dose (mrem) \\
\hline & Maximum & Maximum \\
\hline Am-241 & 0.030 & 4.77E-05 \\
\hline $\mathrm{Pu}-238$ & 0.0786 & $1.05 \mathrm{E}-04$ \\
\hline Pu-239 & 0.027 & $3.99 \mathrm{E}-05$ \\
\hline Ra-226 & 0.66 & $1.37 \mathrm{E}-02$ \\
\hline U-234 & 0.51 & $1.76 \mathrm{E}-04$ \\
\hline U-235 & 0.034 & $5.81 \mathrm{E}-05$ \\
\hline U-238 & 1.6 & 8.91E-02 \\
\hline Sr-90 & 0.81 & $5.17 \mathrm{E}-05$ \\
\hline Cs-137 & 7.4 & 4.72E-02 \\
\hline Co-60 & 23.3 & $6.48 \mathrm{E}-01$ \\
\hline Eu-152 & 0.059 & $7.45 \mathrm{E}-04$ \\
\hline
\end{tabular}

Stop [If last alternative proceed to Step 4, box 4c. If want to analyze another alternative, see Chapter 2, Section 2.4] 


\section{Step 4. Develop Release Limits (Chapter 2, Section 2.4.2)}

\section{Alternative B}

Crush and reuse the concrete without decontamination

\section{B1}

\begin{tabular}{|ccc}
\hline \multirow{2}{*}{ Operational Costs } & & \\
\cline { 2 - 2 } & \multicolumn{1}{c}{ Operation } & Cost $(\$)$ \\
\cline { 2 - 3 } & Crush Concrete & 2,239 \\
& Management Costs & 10,000 \\
& $\begin{array}{l}\text { Other Costs } \\
\text { (demolishing) }\end{array}$ & 3,245 \\
\hline \begin{tabular}{l} 
Total \\
\hline
\end{tabular} & $\$ 15,484$ \\
\hline
\end{tabular}

B2

Transportation Costs

\section{Distance}

Origin Destination \# of Shipments $\quad(\mathrm{km})$

$\operatorname{Cost}(\$)$

No transportation cost because concrete which is removed would be free released and would be used on-site.

Total

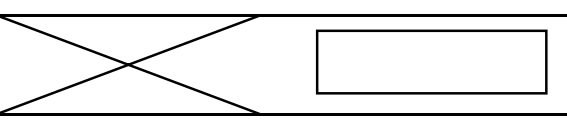




\section{Step 4. Develop Release Limits (Chapter 2, Section 2.4.2)}

\section{Alternative B (Cont.)}

Crush and reuse the concrete without decontamination.

B3

\section{Transportation Impacts}

\begin{tabular}{ccccc}
\hline & & Distance & Dose \\
Origin & Destination & \# of Shipments & $(\mathrm{km})$ & (person-rem) \\
\hline
\end{tabular}

No transportation impacts because concrete which would be free released would be used on-site.

Total




\section{Step 4. Develop Release Limits (Chapter 2, Section 2.4.2)}

\section{Alternative B (Cont.)}

Crush and reuse the concrete without decontamination

B4

\section{Concrete Reuse-Impacts}

\begin{tabular}{|c|c|c|}
\hline \multirow[b]{2}{*}{ Isotope } & \multirow{2}{*}{$\begin{array}{l}\begin{array}{c}\text { Concentration } \\
(\mathrm{pCi} / \mathrm{g})\end{array} \\
\text { Maximum }\end{array}$} & \multirow{2}{*}{$\begin{array}{l}\text { Dose (mrem) } \\
\text { Maximum }\end{array}$} \\
\hline & & \\
\hline Am-241 & $6.37 \mathrm{E}-02$ & $1.15 \mathrm{E}-04$ \\
\hline Pu-238 & $1.66 \mathrm{E}-01$ & $2.53 \mathrm{E}-04$ \\
\hline $\mathrm{Pu}-239$ & 5.69E-02 & $9.59 \mathrm{E}-05$ \\
\hline $\mathrm{Ra}-226$ & $1.39 \mathrm{E}+00$ & $3.30 \mathrm{E}-02$ \\
\hline U-234 & $1.08 \mathrm{E}+00$ & $4.23 \mathrm{E}-04$ \\
\hline U-235 & $7.21 \mathrm{E}-02$ & $1.40 \mathrm{E}-04$ \\
\hline U-238 & $3.41 \mathrm{E}+00$ & $2.14 \mathrm{E}-01$ \\
\hline Sr-90 & $1.71 \mathrm{E}+00$ & $1.24 \mathrm{E}-04$ \\
\hline Cs-137 & $1.56 \mathrm{E}+01$ & $1.13 \mathrm{E}-02$ \\
\hline Co-60 & $4.91 \mathrm{E}+01$ & $1.56 \mathrm{E}+00$ \\
\hline Eu-152 & $1.24 \mathrm{E}-01$ & $1.79 \mathrm{E}-03$ \\
\hline Total & & $1.92 \mathrm{E}+00$ \\
\hline
\end{tabular}

Stop [If last alternative proceed to Step 4, box 4c. If want to analyze another alternative, see Chapter 2, Section 2.4] 


\section{Step 4. Develop Release Limits (Chapter 2, Section 2.4.3)}

\section{Alternative C}

Decontaminate the concrete material, dispose of all low-level waste (LLW), demolish the structure, and dispose of the concrete material at a nonradiological landfill or reuse as backfill material

$\mathrm{C}_{-} \mathrm{a}$

\section{Decontamination Method(s)}

\begin{tabular}{|c|c|c|c|}
\hline $\begin{array}{l}\text { Decontamination } \\
\text { Method }\end{array}$ & $\begin{array}{l}\text { ontamination } \\
\text { Factor }\end{array}$ & Waste Generation & Cost $(\$)$ \\
\hline $\begin{array}{l}\text { Automated floor and wall } \\
\text { scabbling for floor and wall } \\
\text { contamination, respectively }\end{array}$ & 0.1 & $190.3 \mathrm{ft}^{3}$ & $\$ 34,718$ \\
\hline Total & & $190.3 \mathrm{ft}^{3}$ & $\$ 34,718$ \\
\hline
\end{tabular}

$\mathrm{C}_{-} \mathrm{b}$

\section{Operational Costs}

\begin{tabular}{lc}
\multicolumn{1}{c}{ Operation } & Cost $(\$)$ \\
\hline Demolish Structure & 3,245 \\
Management Costs & 10,000 \\
Packaging/Container & 2,200 \\
Costs & - \\
Other Costs & $12,367+1,255=13,622$ \\
Disposal Costs & $\$ 29,067$ \\
\hline Total &
\end{tabular}




\section{Step 4. Develop Release Limits (Chapter 2, Section 2.4.3)}

\section{Alternative C (Cont.)}

Decontaminate the concrete material, dispose of all low-level waste (LLW), demolish the structure and dispose of the concrete material at a nonradiological landfill or reuse as backfill material

$\mathrm{C}_{-} \mathrm{c}$

\section{Transportation Costs}

\begin{tabular}{lcccc}
\hline \multicolumn{1}{c}{ Origin } & Destination & \# of Shipments & Distance $(\mathrm{km})$ & Cost $(\$)$ \\
\hline $\begin{array}{l}\text { Trickle filter } \\
\text { secondary waste } \\
\text { (contaminated concrete) } \\
\begin{array}{l}\text { Decontaminated } \\
\text { concrete }\end{array}\end{array}$ & Envirocare & 1 & 600 & 803 \\
\hline Cotal & CD landfill & 1 & 40 & 151 \\
\hline
\end{tabular}

$\mathrm{C}_{-} \mathrm{d}$

Transportation Impacts

Dose

\begin{tabular}{ccccc} 
Origin & Destination & \# of Shipments & Distance $(\mathrm{km})$ & (person-rem) \\
\hline $\begin{array}{l}\text { Trickle filter } \\
\text { secondary waste } \\
\begin{array}{l}\text { Decontaminated } \\
\text { concrete }\end{array}\end{array}$ & Envirocare & 1 & 600 & $1.9 \mathrm{E}-04$ \\
\hline Total & 1 & 40 & $9.0 \mathrm{E}-06$ \\
\hline
\end{tabular}




\section{Step 4. Develop Release Limits (Chapter 2, Section 2.4.3)}

\section{Alternative C (Cont.)}

Decontaminate the concrete material, dispose of all low-level waste (LLW), demolish the structure, and dispose of the concrete material at a nonradiological landfill or reuse as backfill material

C_e

\section{Concrete Disposal}

\begin{tabular}{|c|c|c|c|}
\hline & & $\begin{array}{c}\text { Concentration } \\
(\mathrm{pCi}) \\
\end{array}$ & Dose (mrem) \\
\hline Receptor & Isotope & Maximum & Maximum \\
\hline Driver & $\begin{array}{l}\text { Am-241 } \\
\text { Pu-238 } \\
\text { Pu-239 } \\
\text { Ra-226 } \\
\text { U-234 } \\
\text { U-235 } \\
\text { U-238 } \\
\text { Sr-90 } \\
\text { Cs-137 } \\
\text { Co-60 } \\
\text { Eu- } 152\end{array}$ & $\begin{array}{l}2.58 \mathrm{E}+06 \\
6.71 \mathrm{E}+06 \\
2.30 \mathrm{E}+06 \\
5.63 \mathrm{E}+07 \\
4.39 \mathrm{E}+07 \\
2.92 \mathrm{E}+06 \\
1.38 \mathrm{E}+08 \\
6.92 \mathrm{E}+07 \\
6.32 \mathrm{E}+08 \\
1.99 \mathrm{E}+09 \\
5.04 \mathrm{E}+06\end{array}$ & $\begin{array}{l}2.37 \mathrm{E}-08 \\
4.56 \mathrm{E}-11 \\
4.61 \mathrm{E}-10 \\
5.18 \mathrm{E}-04 \\
6.14 \mathrm{E}-09 \\
1.75 \mathrm{E}-06 \\
1.44 \mathrm{E}-05 \\
0.00 \\
1.77 \mathrm{E}-03 \\
2.63 \mathrm{E}-02 \\
2.82 \mathrm{E}-05\end{array}$ \\
\hline Total & & & $2.86 \mathrm{E}-02$ \\
\hline $\begin{array}{l}\text { Landfill } \\
\text { W orker }\end{array}$ & $\begin{array}{l}\text { Am-241 } \\
\text { Pu-238 } \\
\text { Pu-239 } \\
\text { Ra-226 } \\
\text { U-234 } \\
\text { U-235 } \\
\text { U-238 } \\
\text { Sr-90 } \\
\text { Cs-137 } \\
\text { Co-60 } \\
\text { Eu- } 152\end{array}$ & $\begin{array}{l}2.58 \mathrm{E}+06 \\
6.71 \mathrm{E}+06 \\
2.30 \mathrm{E}+06 \\
5.63 \mathrm{E}+07 \\
4.39 \mathrm{E}+07 \\
2.92 \mathrm{E}+06 \\
1.38 \mathrm{E}+08 \\
6.92 \mathrm{E}+07 \\
6.32 \mathrm{E}+08 \\
1.99 \mathrm{E}+09 \\
5.04 \mathrm{E}+06\end{array}$ & $\begin{array}{l}1.68 \mathrm{E}-05 \\
3.82 \mathrm{E}-05 \\
1.45 \mathrm{E}-05 \\
2.65 \mathrm{E}-04 \\
8.34 \mathrm{E}-05 \\
6.13 \mathrm{E}-06 \\
2.49 \mathrm{E}-04 \\
1.32 \mathrm{E}-06 \\
8.84 \mathrm{E}-04 \\
1.33 \mathrm{E}-02 \\
1.46 \mathrm{E}-05\end{array}$ \\
\hline Total & & & 1.49E-02 \\
\hline
\end{tabular}




\section{Step 4. Develop Release Limits (Chapter 2, Section 2.4.3)}

\section{Alternative C (Cont.)}

Decontaminate the concrete material, dispose of all low-level waste (LLW), demolish the structure, and dispose of the concrete material at a nonradiological landfill or reuse as

C_f

Disposal-Future Resident

\begin{tabular}{lll}
\hline & $\begin{array}{c}\text { Concentration } \\
(\mathrm{pCi} / \mathrm{g})\end{array}$ & \\
\cline { 2 - 3 } Isotope & Maximum & Dose (mrem) \\
\cline { 2 - 3 } $\mathrm{Am}-241$ & 0.030 & \\
$\mathrm{Pu}-238$ & 0.0786 & $1.88 \mathrm{E}-03$ \\
$\mathrm{Pu}-239$ & 0.027 & $1.66 \mathrm{E}-04$ \\
$\mathrm{Ra}-226$ & 0.66 & $6.34 \mathrm{E}-05$ \\
$\mathrm{U}-234$ & 0.51 & $2.47 \mathrm{E}-01$ \\
$\mathrm{U}-235$ & 0.034 & $2.37 \mathrm{E}-04$ \\
$\mathrm{U}-238$ & 1.6 & $2.75 \mathrm{E}-04$ \\
$\mathrm{Sr}-90$ & 0.81 & $4.60 \mathrm{E}-03$ \\
$\mathrm{Cs}-137$ & 7.4 & $2.16 \mathrm{E}-02$ \\
$\mathrm{Co}-60$ & 23.3 & $8.97 \mathrm{E}-02$ \\
Eu-152 & 0.059 & $1.10 \mathrm{E}+00$ \\
& & $1.21 \mathrm{E}-03$
\end{tabular}

Stop [If last alternative, proceed to Step 4, box 4c. If want to analyze another alternative, see Chapter 2, Section 2.4] 


\section{Step 4. Develop Release Limits (Chapter 2, Section 2.4.4)}

\section{Alternative D}

Demolish the structure, and dispose of the concrete material at a nonradiological landfill or reuse as backfill material

$\mathrm{D}_{-} \mathrm{a}$

\begin{tabular}{|c|c|c|}
\hline \multirow[t]{7}{*}{ Operational Costs } & Operation & $\begin{array}{l}\text { Cost } \\
(\$)\end{array}$ \\
\hline & Demolish Structure & 3,245 \\
\hline & Management Costs & 10,000 \\
\hline & $\begin{array}{l}\text { Packaging/Container } \\
\text { Costs }\end{array}$ & - \\
\hline & Disposal Costs & 1,431 \\
\hline & Other Costs & - \\
\hline & Total & $\$ 14,676$ \\
\hline
\end{tabular}




\section{Step 4. Develop Release Limits (Chapter 2, Section 2.4.4)}

\section{Alternative D (Cont.)}

Demolish the structure, and dispose of the concrete material at a nonradiological landfill or reuse as backfill material

D_b

\section{Transportation Costs}

\begin{tabular}{llccc}
\hline \multicolumn{1}{c}{ Origin } & Destination & \# of Shipments & Distance $(\mathrm{km})$ & Cost $(\$)$ \\
\hline $\begin{array}{l}\text { Trickle filter } \\
\text { crushed concrete }\end{array}$ & C\&D landfill & 1 & 40 & 172 \\
\hline Total & & & & \\
\hline
\end{tabular}

$\mathrm{D}_{-} \mathrm{c}$

Transportation Impacts

Dose

\begin{tabular}{lcccc} 
Origin & Destination & \# of Shipments & Distance $(\mathrm{km})$ & (person-rem) \\
\hline $\begin{array}{l}\text { Trickle filter } \\
\text { crushed concrete }\end{array}$ & C\&D landfill & 1 & 40 & $2.17 \mathrm{E}-05$ \\
& & & \\
\hline Total & & $2.17 \mathrm{E}-05$ \\
\hline
\end{tabular}




\section{Step 4. Develop Release Limits (Chapter 2, Section 2.4.4)}

\section{Alternative D (Cont.)}

Demolish the structure, and dispose of the concrete material at a nonradiological landfill or reuse as backfill material

D_d

\section{Concrete Disposal}

Concentration

(pCi)

\begin{tabular}{lll} 
Receptor & Isotope & Maxim \\
\hline \multirow{2}{*}{ Driver } & Am-241 & $6.20 \mathrm{E}+06$ \\
& Pu-238 & $1.61 \mathrm{E}+07$ \\
& Pu-239 & $5.54 \mathrm{E}+06$ \\
& Ra-226 & $1.35 \mathrm{E}+08$ \\
& $\mathrm{U}-234$ & $1.05 \mathrm{E}+08$ \\
& $\mathrm{U}-235$ & $7.02 \mathrm{E}+06$ \\
& $\mathrm{U}-238$ & $3.32 \mathrm{E}+08$ \\
& Sr-90 & $1.66 \mathrm{E}+08$ \\
& Cs-137 & $1.52 \mathrm{E}+09$ \\
& Co-60 & $4.78 \mathrm{E}+09$ \\
& Eu-152 & $1.21 \mathrm{E}+07$
\end{tabular}

Dose (mrem)

Maximum

$5.70 \mathrm{E}-08$

$1.10 \mathrm{E}-10$

$1.11 \mathrm{E}-09$

$1.25 \mathrm{E}-03$

$1.48 \mathrm{E}-08$

4.21E-06

$3.46 \mathrm{E}-05$

0.0

$4.25 \mathrm{E}-03$

$6.31 \mathrm{E}-02$

$6.78 \mathrm{E}-05$

\begin{tabular}{llll}
\hline \multirow{2}{*}{ Total } & & & $6.87 \mathrm{E}-02$ \\
\hline Landfill & Am-241 & $6.20 \mathrm{E}+06$ & $4.03 \mathrm{E}-05$ \\
Worker & Pu-238 & $1.61 \mathrm{E}+07$ & $9.19 \mathrm{E}-05$ \\
& Pu-239 & $5.54 \mathrm{E}+06$ & $3.49 \mathrm{E}-05$ \\
& Ra-226 & $1.35 \mathrm{E}+08$ & $6.37 \mathrm{E}-04$ \\
& $\mathrm{U}-234$ & $1.05 \mathrm{E}+08$ & $2.00 \mathrm{E}-04$ \\
& $\mathrm{U}-235$ & $7.02 \mathrm{E}+06$ & $1.47 \mathrm{E}-05$ \\
& $\mathrm{U}-238$ & $3.32 \mathrm{E}+08$ & $5.98 \mathrm{E}-04$ \\
& Sr-90 & $1.66 \mathrm{E}+08$ & $3.16 \mathrm{E}-06$ \\
& Cs-137 & $1.52 \mathrm{E}+09$ & $2.13 \mathrm{E}-03$ \\
& Co-60 & $4.78 \mathrm{E}+09$ & $3.20 \mathrm{E}-02$ \\
\hline \multirow{2}{*}{ Total } & Eu-152 & $1.21 \mathrm{E}+07$ & $3.51 \mathrm{E}-05$ \\
\hline
\end{tabular}




\section{Step 4. Develop Release Limits (Chapter 2, Section 2.4.4)}

\section{Alternative D (Cont.)}

Demolish the structure, and dispose the concrete material at a nonradiological landfill or reuse as backfill material.

D_e

Disposal-Future Resident

\begin{tabular}{|c|c|c|}
\hline \multirow[b]{2}{*}{ Isotope } & $\begin{array}{l}\text { Concentration } \\
\qquad(\mathrm{pCi} / \mathrm{g})\end{array}$ & Dose (mrem) \\
\hline & Maximum & Maximum \\
\hline $\begin{array}{l}\text { Am-241 } \\
\text { Pu-238 } \\
\text { Pu-239 } \\
\text { Ra-226 } \\
\text { U-234 } \\
\text { U-235 } \\
\text { U-238 } \\
\text { Sr-90 } \\
\text { Cs-137 } \\
\text { Co-60 } \\
\text { Eu-152 }\end{array}$ & $\begin{array}{l}6.37 \mathrm{E}-02 \\
1.66 \mathrm{E}-01 \\
5.69 \mathrm{E}-02 \\
1.39 \mathrm{E}+00 \\
1.08 \mathrm{E}+00 \\
7.21 \mathrm{E}-02 \\
3.41 \mathrm{E}+00 \\
1.71 \mathrm{E}+00 \\
1.56 \mathrm{E}+01 \\
4.91 \mathrm{E}+01 \\
1.24 \mathrm{E}-01\end{array}$ & $\begin{array}{l}4.52 \mathrm{E}-03 \\
3.98 \mathrm{E}-04 \\
1.52 \mathrm{E}-04 \\
5.93 \mathrm{E}-01 \\
5.70 \mathrm{E}-04 \\
6.62 \mathrm{E}-04 \\
1.11 \mathrm{E}-02 \\
5.19 \mathrm{E}-02 \\
2.16 \mathrm{E}-01 \\
2.64 \mathrm{E}+00 \\
2.92 \mathrm{E}-03\end{array}$ \\
\hline Total & & $3.53 \mathrm{E}+00$ \\
\hline
\end{tabular}

Stop [If last alternative, proceed to Step 4, box 4c. If want to analyze another alternative, see Chapter 2, Section 2.4] 


\section{Step 4. Develop Release Limits (Chapter 2, Section 2.4.5)}

Alternative E

Demolish the structure and dispose of the concrete material at a low-level waste (LLW) facility

E_a

Operational Costs

\begin{tabular}{lc}
\hline \multicolumn{1}{c}{ Operation } & \multicolumn{1}{c}{$\begin{array}{c}\text { Cost } \\
(\$)\end{array}$} \\
\hline Demolish Structure & 3,245 \\
Management Costs & 10,000 \\
Packaging/Container & 25,482 \\
Costs & \\
Disposal Costs & 100,490 \\
& \\
\hline Total & $\$ 139,217$ \\
\hline
\end{tabular}




\section{Step 4. Develop Release Limits (Chapter 2, Section 2.4.5)}

\section{Alternative E (Cont.)}

Demolish the structure and dispose the concrete material at a low-level waste facility

E_b

Transportation Costs

\begin{tabular}{llccc}
\hline \multicolumn{1}{c}{ Origin } & Destination & \# of Shipments & $\begin{array}{c}\text { Distance } \\
(\mathrm{km})\end{array}$ & $\begin{array}{c}\text { Cost } \\
(\$)\end{array}$ \\
\hline $\begin{array}{l}\text { Trickle filter } \\
\text { contaminated } \\
\text { concrete }\end{array}$ & Envirocare & 6 & 600 & 4,816 \\
\hline Total & & & 4,816 \\
\hline
\end{tabular}

E_c

Transportation Impacts

\begin{tabular}{llccc}
\hline \multicolumn{1}{c}{ Origin } & Destination & \# of Shipments & $\begin{array}{c}\text { Distance } \\
(\mathrm{km})\end{array}$ & $\begin{array}{c}\text { Dose } \\
\text { (person-rem) }\end{array}$ \\
\hline $\begin{array}{l}\text { Trickle filter } \\
\text { contaminated } \\
\begin{array}{l}\text { concrete } \\
\text { Total }\end{array}\end{array}$ & 6 & 600 & $3.25 \mathrm{E}-04$ \\
\hline
\end{tabular}

Stop [If last alternative, proceed to Step 4, box 4c. If want to analyze another alternative, see Chapter 2, Section 2.4] 


\section{Step 4. Develop Release Limits (Chapter 2, Section 2.4.6)}

\section{Alternative F}

Decontaminate and reuse the building as an office

$\mathrm{F}_{-} \mathrm{a}$

\section{Decontamination Method(s)}

\begin{tabular}{cccc}
\hline $\begin{array}{c}\text { Decontamination } \\
\text { Method }\end{array}$ & $\begin{array}{c}\text { Decontamination } \\
\text { Factor }\end{array}$ & $\begin{array}{c}\text { Waste Generation } \\
\left(\mathrm{ft}^{3}\right)\end{array}$ & $\begin{array}{c}\text { Cost } \\
(\$)\end{array}$ \\
\hline
\end{tabular}

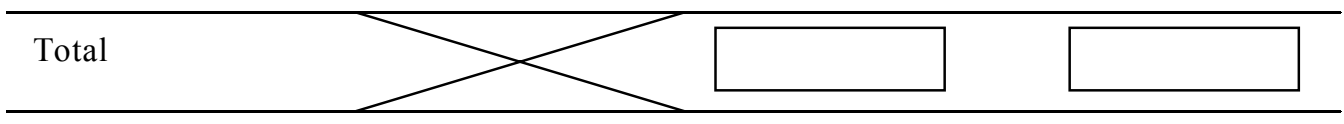

F_b

Transportation Costs

\begin{tabular}{lcccc}
\hline Origin & Destination & \# of Shipments & $\begin{array}{c}\text { Distance } \\
(\mathrm{km})\end{array}$ & $\begin{array}{c}\text { Cost } \\
(\$)\end{array}$ \\
\hline Total & & \\
\hline
\end{tabular}




\section{Step 4. Develop Release Limits (Chapter 2, Section 2.4.6)}

\section{Alternative F (Cont.)}

Decontaminate and reuse the building as an office

$\mathrm{F}_{-} \mathrm{c}$

Transportation Impacts

\begin{tabular}{lcccc}
\hline Origin & Destination & \# of Shipments & $\begin{array}{c}\text { Distance } \\
(\mathrm{km})\end{array}$ & $\begin{array}{c}\text { Dose } \\
\text { (person-rem) }\end{array}$ \\
\hline & & & \\
\hline Total & & & \\
\hline
\end{tabular}




\section{Step 4. Develop Release Limits (Chapter 2, Section 2.4.6)}

\section{Alternative F (Cont.)}

Decontaminate and reuse the building as an office

F_d

\section{Concrete Reuse-Impacts}

\begin{tabular}{|c|c|c|c|c|}
\hline \multirow[b]{2}{*}{ Isotope } & \multicolumn{2}{|c|}{$\begin{array}{c}\text { Concentration } \\
\left(\mathrm{pCi} / \mathrm{g} \text { or } \mathrm{DPM} / 100 \mathrm{~cm}^{2}\right)\end{array}$} & \multicolumn{2}{|c|}{ Dose (mrem) } \\
\hline & Average & Maximum & Average & Maximum \\
\hline
\end{tabular}

$\square \square$

Stop [If last alternative, proceed to Step 4, box 4c. If want to analyze another alternative, see Chapter 2, Section 2.4] 


\section{Step 4. Develop Release Limits (Chapter 2, Section 2.4.7)}

\section{Alternative G}

The concrete structure will be demolished and entombed on-site

G_a

Operational Costs

\begin{tabular}{lc}
\hline \multicolumn{1}{c}{ Operation } & $\begin{array}{c}\text { Cost } \\
(\$)\end{array}$ \\
\hline Demolish Structure & \\
Other Costs \\
\hline Total \\
\hline
\end{tabular}




\section{Step 4. Develop Release Limits (Chapter 2, Section 2.4.7)}

\section{Alternative G (Cont.)}

The concrete structure will be demolished and entombed on-site

G_b

Disposal-Future Resident

\begin{tabular}{|c|c|c|c|c|}
\hline \multirow[b]{2}{*}{ Isotope } & \multicolumn{2}{|c|}{$\begin{array}{c}\text { Concentration } \\
\left(\mathrm{pCi} / \mathrm{g} \text { or } \mathrm{DPM} / 100 \mathrm{~cm}^{2}\right)\end{array}$} & \multicolumn{2}{|c|}{ Dose (mrem) } \\
\hline & Average & Maximum & Average & Maximum \\
\hline
\end{tabular}

Total

$+$




\section{Step 4. Develop Release Limits (Chapter 2, Section 2.4.8)}

$4 c$ Summary of Alternatives

Summary of Costs/Radiological Impacts

Costs (\$)

Alternative

Decontamination + Operational

Dose (person-rem or mrem)

Transportation

Population Driver

Worker

Future

Resident

A

B

C

D $\quad 14,676$

E

E 139,217

15,484
803

$1.90 \mathrm{E}-04$

Population

Driver

$34,718+29,776$

$34,718+29,067$

954

172

2.17E-05 6.87E-02

$3.58 \mathrm{E}-02$

3.53

4,816

3.25E-04 


\section{Step 4. Develop Release Limits (Chapter 2, Section 2.4.9)}

4d Proposed Authorized Release Limits

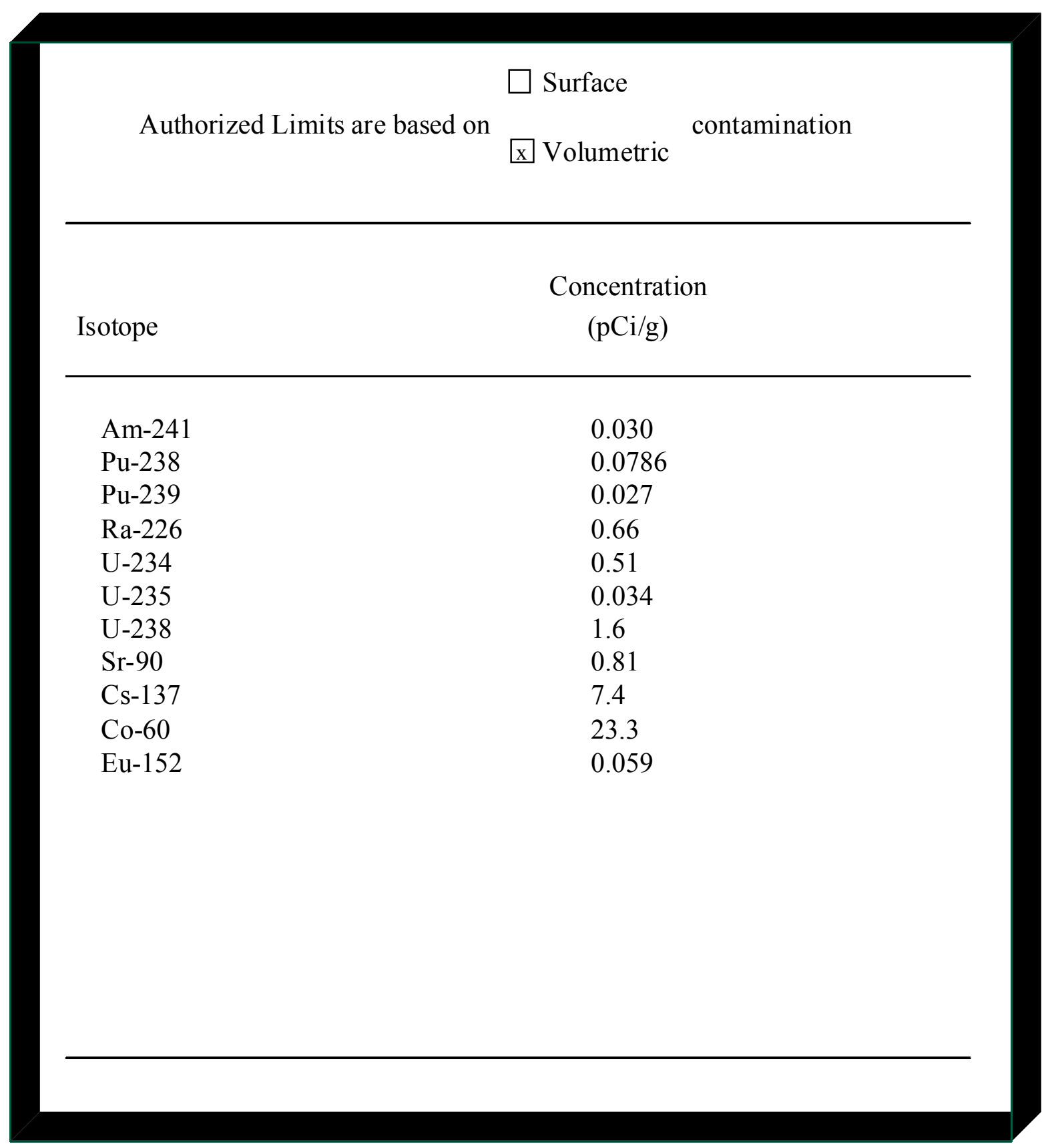

Go to Next Page 
Step 5. Compile and Submit Application for DOE Operations Approval (Chapter 2, Sections 2.4.9 and 2.5)

5a Restrictions on Use Following Release (if applicable)

Decontaminate the concrete material at the trickle filter structure, dispose of all low-level waste (LLW), and crush and reuse the decontaminated concrete on-site for constructing road base. Before reusing, make sure decontaminated concrete meets the authorized release limits. If the concrete cannot be used on-site, send it to sanitary landfill. 
Step 5. Compile and Submit Application for DOE Operations Approval (Chapter 2, Section 2.5)

$5 b$

Comments/recommendations by other state or federal agencies (attach documents) 
Step 5. Compile and Submit Application for DOE Operations Approval (Chapter 2, Section 2.8)

Survey Protocols (attach applicable documents) 
APPENDIX B:

APPLICATION FOR THE DEVELOPMENT OF AUTHORIZED

RELEASE LIMITS FOR CONCRETE FROM

THE TRICKLE FILTER - INEEL-SPECIFIC CASE 


$$
\text { B-2 }
$$


Application for the Development of Authorized Release Limits

for Concrete

(A Sample "Walk Through [with INEELSpecific Cost and Risk Estimates]"

for the Trickle Filter) 


\section{Authorized Release Process}

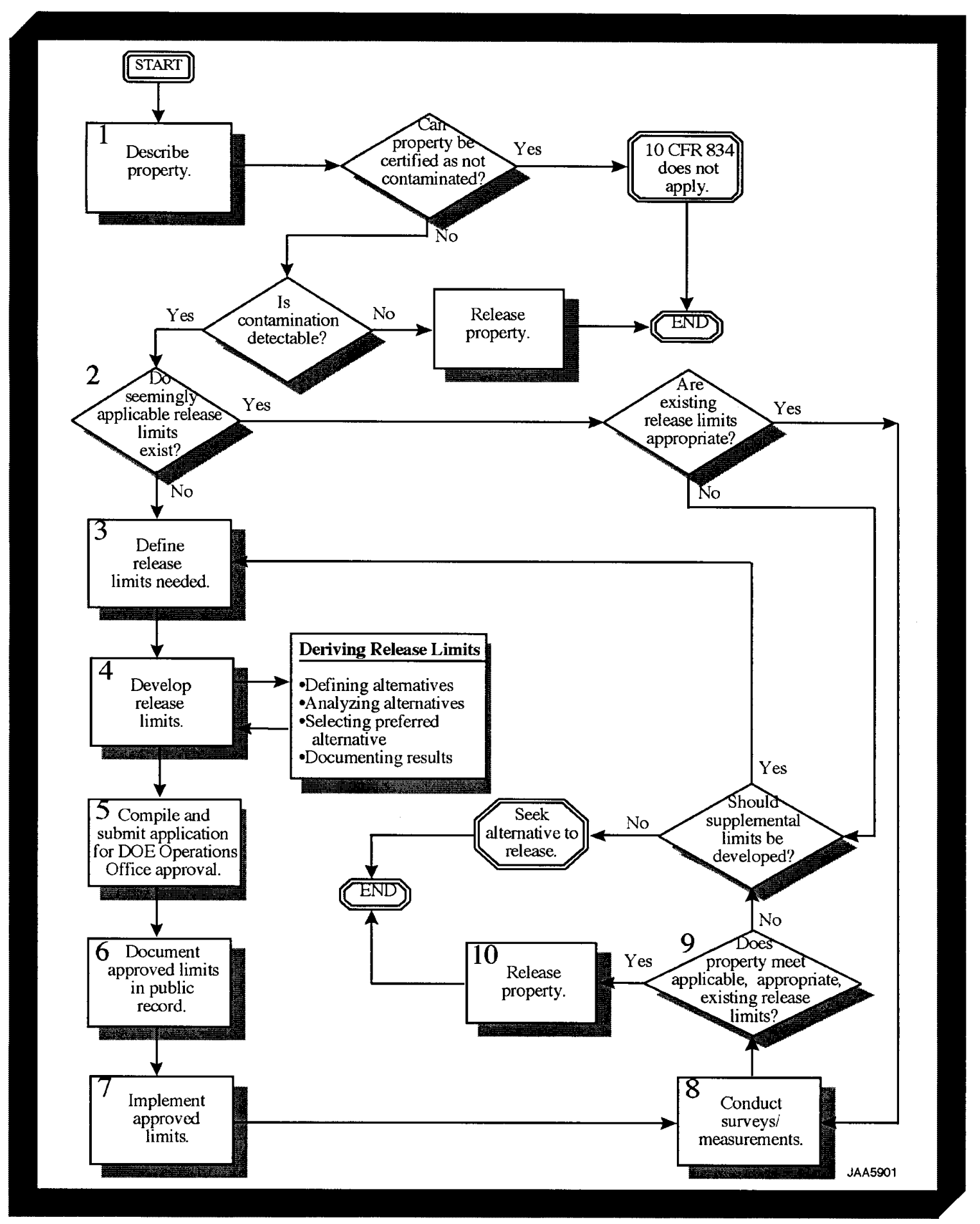




\section{Step 1. Characterize Property and Prepare a Description ( Chapter 2, Section 2.1)}

\section{(All information in the form should be typed)}

\section{1a Physical Characteristics}

Describe the physical characteristics of the concrete material (volume of material, age, location, etc.)

Volume: $1546 \mathrm{ft}^{3}=43.778 \mathrm{~m}^{3}=97.35$ metric tons

(Trickle Filter from the Sewage Treatment Plant at Central Facilities Area 691)

This auxiliary structure was located northwest of the pumphouse. The trickle filter was a 50-ft

diameter, cylindrical-shaped concrete structure. The walls consisted of 8 -ft 2-in. high concrete topped with $5 \mathrm{ft}$ of wood that surrounded the trickler. There was a $3 \times 4$ - $\mathrm{ft}$ door for entry into the trickler. It had a reinforced 4-in. thick concrete slab floor with welded wire mesh. On top of the concrete slab floor was a layer of concrete filter blocks covered with rock filled material $6 \mathrm{ft}$ deep.

\section{1b Radiological History}

Describe the radiological history of the concrete material (i.e., known areas of contamination, etc.)

One sediment sample was collected from inside the trickle filter arm. This was the only place any loose contamination was found. Radionuclides detected and measured in the sample were Am-241, Pu-238, Pu-239, Ra-226, U-234, U-245, U-238, Sr-90, Cs-137, Co-60, Eu-152, and Ru-103.

No contamination was picked up on the smears or large area wipes for the trickler arm pipes and columns, but removable soil and rust from the pipe $\mathrm{read}>1000 \mathrm{dpm} / 100 \mathrm{~cm}^{2}$ beta/gamma. The direct scans from the interior and exterior walls (metal, wood siding, and concrete) of the trickle filter were $<1000 \mathrm{dpm} / 100 \mathrm{~cm}^{2}$ beta/gamma and $<20 \mathrm{dpm} / 100 \mathrm{~cm}^{2}$ alpha. 
Step 1. Characterize Property and Prepare a Description (Chapter 2, Section 2.1)

\section{1c Radiological History Questionnaire}

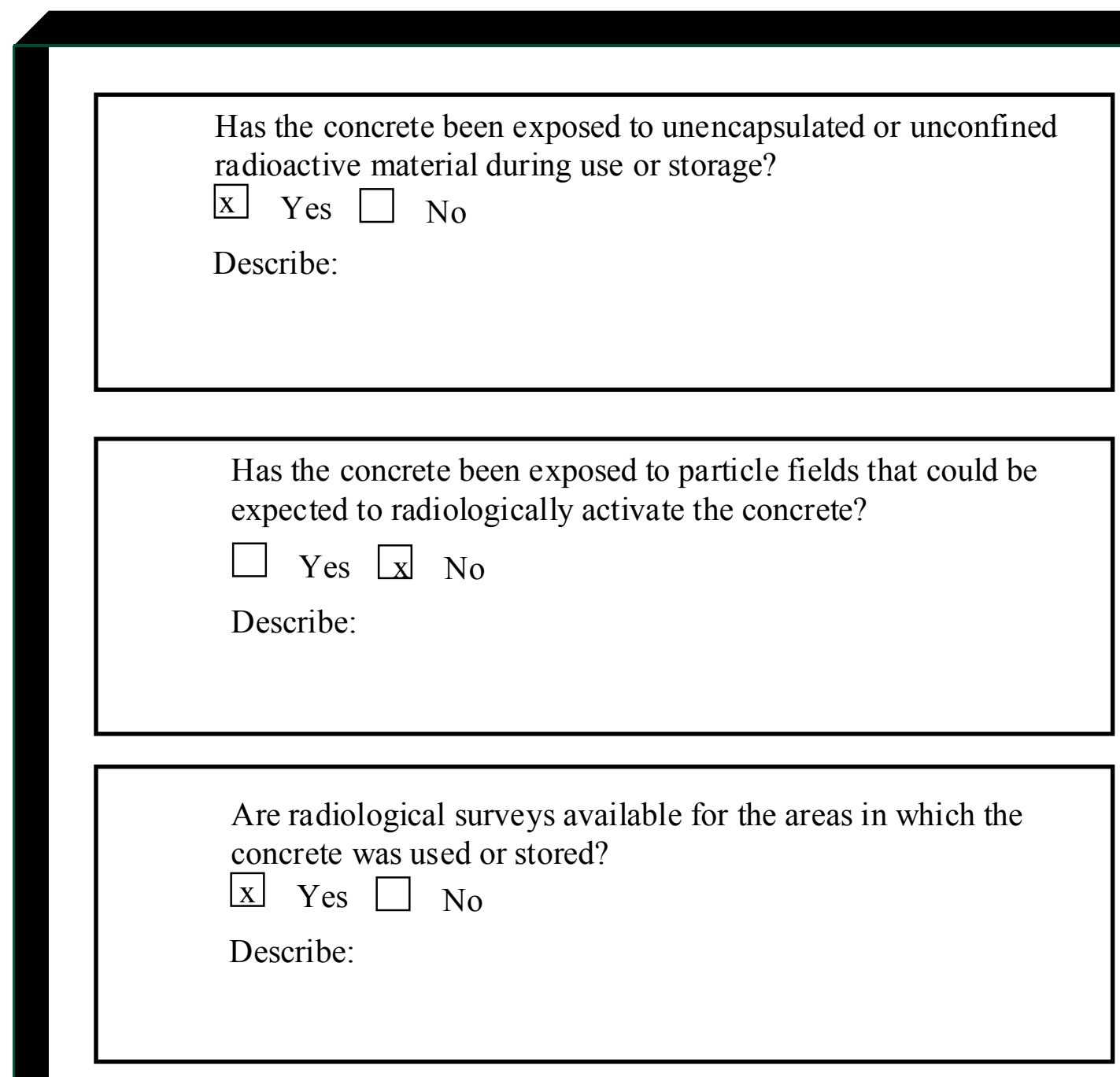

Are valid comparison data available for naturally occurring radionuclides in concrete that HAS NOT been used, stored, or exposed to transferable radioactive material?

$\square$ Yes $\mathrm{x}$ No

Describe: 


\section{Step 1. Characterize Property and Prepare a Description (Chapter 2, Section 2.1)}

\section{1d Radiological Determination}

\section{Based on the answers provided in questions $1 \mathrm{~b}, 1 \mathrm{c}$, and $1 \mathrm{~d}$, the concrete being} released is determined to be radioactive non radioactive (circle one).

\section{Basis for nonradioactive}

Radiological history, process knowledge, and release surveys indicate contamination is unlikely (answered "no" to all questions in 1c).

Signed: Name

Date:

Date

(Radiological Control Representative)

Signed: Name

Date: Date

(Facility Manager)

\section{Check one box:}

The material has been determined to be nonradioactive. DOE Order 5400.5 and 10 CFR 834 do not apply. Release material.

口 The material is considered to be radioactive. Go to Step 1, box e. 


\section{Step 1. Characterize Property and Prepare a Description} (Chapter 2, Section 2.1)

1e Results of the Radiological Survey

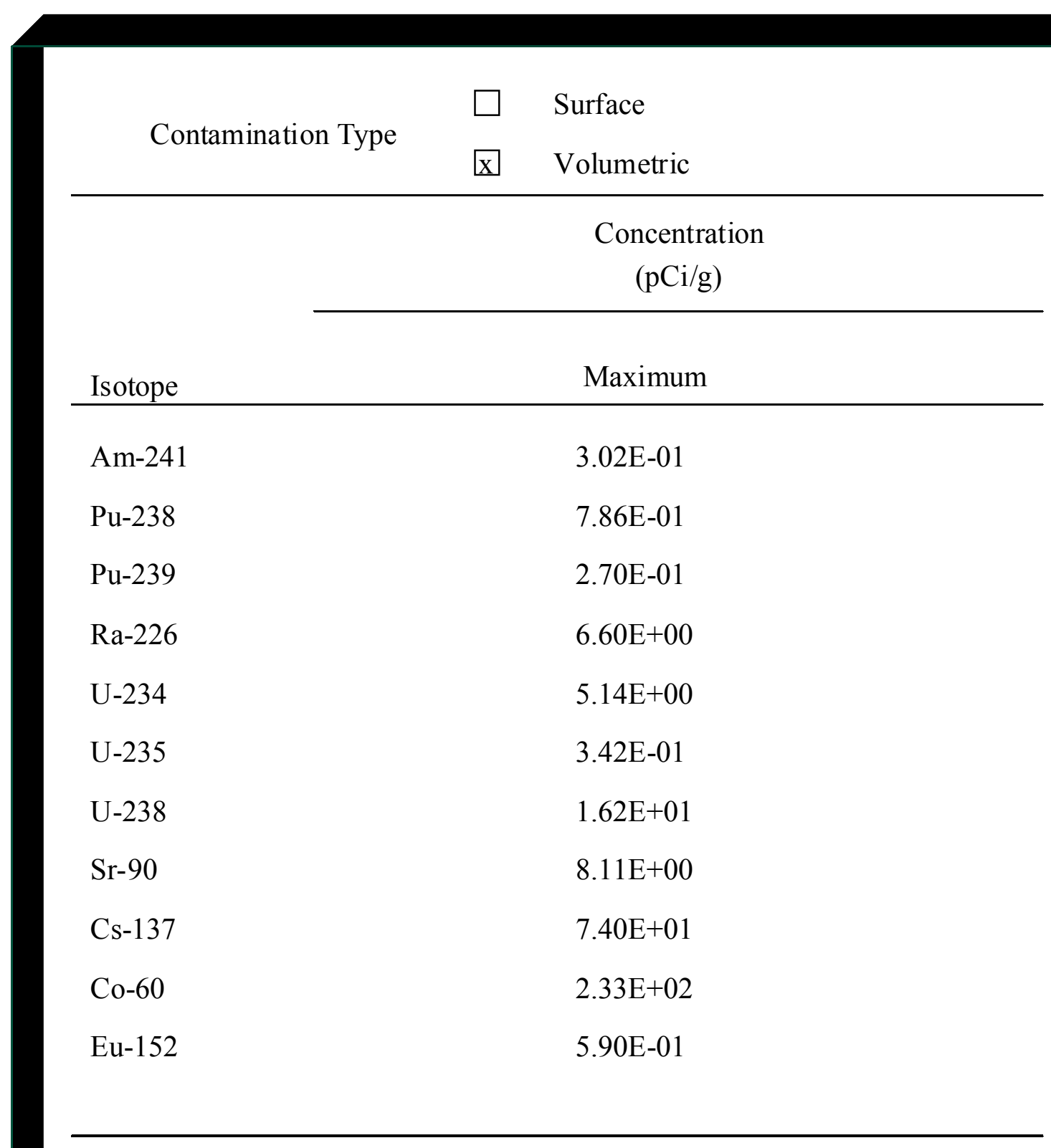




\section{Step 2. Determine Whether Applicable Authorized or Supplemental Limits Exist (Chapter 2, Section 2.2)}

2a Check for existing release limits

Check one box:

Concrete material is contaminated only on the external surfaces.

Go to Step 2, box 2b

$\mathrm{x}$ Concrete material is contaminated throughout the volume of the material, and authorized release limits have not been derived for a similar concrete material.

Go to Step 3, box 3a

Concrete material is contaminated throughout the volume of the material and authorized release limits have been derived for other concrete materials.

Go to Step 2, box 2d 


\section{Step 2. Determine Whether Applicable Authorized or Supplemental Limits Exist (Chapter 2, Section 2.2)}

\section{2b Surface Activity Guidelines}

\begin{tabular}{|c|c|c|c|}
\hline \multicolumn{4}{|c|}{ Allowable Total Residual Surface Activity $(\mathrm{dpm} / 100 \mathrm{sq}-\mathrm{cm})^{1}$} \\
\hline RA DION U CLIDES ${ }^{2}$ & A V ER A GE ${ }^{3 / 4}$ & M AXIM UM ${ }^{4 / 5}$ & R EM OVAB LE ${ }^{2}$ \\
\hline $\begin{array}{l}\text { Group } 1-\text { Transurancics, I-125, I-129, Ac-227, Ra-226, Ra- } \\
228 \text {, Th-228, Th-230, Pa-231 }\end{array}$ & 100 & 300 & 20 \\
\hline $\begin{array}{l}\text { G roup } 2-\text { Th -natura } 1, \mathrm{~S} r-90, \mathrm{I} 26, \mathrm{I}-131, \mathrm{I}-133, \mathrm{R} \text { a- } 223, \mathrm{R} \text { a- } \\
224, \\
\mathrm{U}-232, \mathrm{Th}-232\end{array}$ & 1000 & 3000 & 200 \\
\hline $\begin{array}{l}\text { Group } 3 \text { - U-natural, U - } 235, U-238, \text { and associated decay } \\
\text { products, alpha emitters }\end{array}$ & 5000 & 15000 & 1000 \\
\hline $\begin{array}{l}\text { Group } 4-\text { Beta-gammaemitters (radionuclides with decay } \\
\text { modes other than alpha em ission or spontaneous fission) } \\
\text { except Sr-90 and others noted above? }\end{array}$ & 5000 & 15000 & 1000 \\
\hline Tritium (applicable to surface and subsurface) ${ }^{8}$ & $\mathrm{~N} / \mathrm{A}$ & $\mathrm{N} / \mathrm{A}$ & 10000 \\
\hline
\end{tabular}

*Excerpt from Response to Questions and to Questions and Clarification of Requirements and Processes: DOE 5400.5 , Section II.5 and Chapter IV Imp lementation (Requirements Relating to Residual Radioactive material),
DOE Assistant Secretary for Environment Policyand Assistance (EH-4 ), Nov, 17, 1995 . NOTES: 'As used in this table, $d p m$ (disintegrations per minute) means the rate of emission by radioactive
material as determined by counts per minute measured by an appropratedetectorforbackground, efficiency and
geometric factorsassociated with the instrumentation. $\mathrm{g}$ eo $\mathrm{metric}$ factors associated $w$ ith the instrumentation

${ }^{2}$ Where surface contamination by both alpha-and beta-gamma-emitting radionuclides exists, the limits established for alpha-and beta-gamma-em itting radionuclides should apply independently,

${ }^{3}$ Measurements of average contamination should notbe averaged overanarea of more than $1 \mathrm{sq}-\mathrm{m}$

${ }^{4} T$ he average and maximum dose rates associated with surface contam ination resulting from beta-gamma em it ters should not exceed $0.2 \mathrm{mrad} / \mathrm{h}$, and $1.0 \mathrm{mrad} / \mathrm{h}$, respectively, at $1 \mathrm{~cm}$

${ }^{5} T$ he maximum contamination level applies to an area of not $\mathrm{m}$ ore than $100 \mathrm{sq}-\mathrm{cm}$

${ }^{6}$ The amount of removable material per $100 \mathrm{sq}-\mathrm{cm}$ of surface area should be determined by wiping an area of that size with dry filter or soft absorbent paper, applying moderate pressure, and measuring the amount of radioactive material on the wipe with an appropriate instrument of know $n$ efficiency. When removable based on the actual area and the entire surface should be wiped. It is not necessary to use wiping techniques to measure removable contamination levels if direct scan surveysindicate that the to tal residual surface contam ination levelsare with in the limits for removable contam ination.

${ }^{7} T$ hiscategory of radionuclides includes $m$ ixed fission products, including the SR -90 present in them. It does not apply to $\mathrm{Sr}-90$ that has been separated from the other fission products or mixtures where the Sr-90 has been enrich ed.

${ }^{8}$ Property recently exposed or decontaminated should have measurement (smears) at regular time
o ensure that there is not a build-up of contam ination over time. Because tritium typically penetrates intervals to ensure that there is not a build-up of contam ination over time. Because tritium typically penetrates
materialit contact, the surface guidelines in Group 4 are not applicable to tritium. The Departmenthas reviewed the analysis conducted by the DOE Tritium Surface contam ination Lim its $C$ om mittee ("Recommended Tritium Surface contain in $\mathrm{c}$ residual tritium. The department recommend the use of the state guideline as an interim removable tritium. Measurements demonstrating compliance of the removablefraction of tritium on surfaces with this guideline are acceptable to ensure that nonremovable fractions and residual tritium in mass will not cause exposures thatexceed DOE dose lim itsand constraints.

NOTE: DOE requirements under Order 5400.5 and 10 CFR 834 allow the use of Surface Activity Guidelines (above table) as authorized release limits for residual radioactive material on surfaces only after ALARA process requirements have been met. Therefore the activity levels given in the Surface Activity Guidelines table should not be treated as existing limits until ALARA process requirements have been fulfilled. Dose estimates showing that projected doses are low should be included in documentation supporting the Surface Activity Guidelines. This may be important when the authorized limits are developed as part of a process for releasing surface contaminated concrete materials on a regular basis over a long operational period. 


\section{Step 2. Determine Whether Applicable Authorized or} Supplemental limits Exist (Chapter 2, Section 2.2)

2c-1 Are the Surface Activity Guidelines Appropriate?

Document Number

Estimated Dose Based on the Surface Activity Guidelines

\begin{tabular}{lcll}
\hline & & Measured & \\
& Dose $/\left(\mathrm{dpm} / 100 \mathrm{~cm}^{2}\right)$ & Concentration & Dose \\
Isotope & {$\left[\mathrm{mrem} /\left(\mathrm{dpm} / 100 \mathrm{~cm}^{2}\right)\right]$} & $\left(\mathrm{dpm} / 100 \mathrm{~cm}^{2}\right)$ & $(\mathrm{mrem})$ \\
\hline
\end{tabular}

Line 2c-1 Total (Sum doses from all isotopes) 


\section{Step 2. Determine Whether Applicable Authorized or Supplemental Limits Exist (Chapter 2, Section 2.2)}

2c-2 Are the Surface Activity Guidelines Appropriate?

Write Total (Line 2c.1) from the previous page mrem

Check one box:

Line $2 c-2$ is less than or equal to 1 mrem and the concentrations provided in $\mathbf{1 e}$ are less than those provided in $\mathbf{2} \mathbf{b}$.

See Chaper 2, Sections 2.8, 2.9, and 2.10

Line $2 c-2$ is greater than 1 mrem or an ALARA analysis has not been previously conducted.

Go to Step 3, box 3a 
Step 2. Determine Whether Applicable Authorized or Supplemental Limits Exist (Chapter 2, Section 2.2)

2d Previously Derived Authorized or Supplemental Release Limits (If none exist go to Step 3)

Document Number

Enter the authorized release limit for each isotope

Concentration $(\mathrm{pCi} / \mathrm{g})$

Isotope

Maximum

Average

Go to Next Page 


\section{Step 2. Determine Whether Applicable Authorized or Supplemental Limits Exist (Chapter 2, Section 2.2)}

2e Are the Existing Authorized Release Limits Appropriate?

Check one box:

The concentrations of the isotopes reported in 1e are less than or equal to the authorized release limits reported in $\mathbf{2 d}$.

See Chapter 2, Sections 2.8, 2.9, and 2.10

The concentrations of the isotopes reported in 1e are greater than the authorized release limits reported in $\mathbf{2 d}$; or there are isotopes listed in 1e that are not included in $\mathbf{2 d}$.

Go to Next Page 


\section{Step 3. Define Release Limits Needed (Chapter 2, Section 2.3)}

3a Release Limit Applicability

Release limits will be based on (check all that apply)

$\square$ Surface Contamination (DPM /100 $\mathrm{cm}^{2}$ )

$邓$ Volumetric Contamination ( $\mathrm{pCi} / \mathrm{g}$ )

$\nabla$ One-time release

$\square \quad$ Routine release 


\section{Step 4. Develop Release Limits (Chapter 2, Section 2.4)}

\section{4a Primary ALARA Alternatives}

Check alternatives considered for ALARA analysis

$\mathrm{X}$ A. Decontaminate the concrete material, dispose of all lowlevel waste (LLW), and crush and reuse the decontaminated material

B $\quad$ B. Crush and reuse the concrete without decontamination

D C. Decontaminate the concrete, dispose of all LLW, demolish the structure, and dispose of the decontaminated material as construction debris (nonradiological landfill) or reuse as backfill

$\mathrm{x} \quad$ D. Demolish the structure, and dispose of the concrete material as construction debris (nonradiological landfill no decontamination) or reuse as backfill

E E. Demolish the structure and dispose of all materials as LLW

F. Decontaminate the building and reuse as office space

G. Demolish the building and entomb on-site

\section{4b Secondary ALARA Alternatives}

Indicate the letter of the primary alternative, then the number of the secondary alternative considered (e.g., A1, A2, etc.). 


\section{Step 4. Develop Release Limits (Chapter 2 Section 2.4.1)}

\section{Alternative A}

Decontaminate the concrete material, dispose of all low-level waste (LLW), and crush and reuse the decontaminated material

$\mathrm{A}_{-} \mathrm{a}$

\section{Decontamination Method(s)}

\begin{tabular}{lccc}
\hline $\begin{array}{c}\text { Decontamination } \\
\text { Method }\end{array}$ & $\begin{array}{c}\text { Decontamination } \\
\text { Factor }\end{array}$ & $\begin{array}{c}\text { Waste Generation } \\
\left(\mathrm{ft}^{3}\right)\end{array}$ & $\begin{array}{c}\text { Cost } \\
(\$)\end{array}$ \\
\hline $\begin{array}{l}\text { Automated floor and wall } \\
\text { scabbling for floor and wall } \\
\text { contamination, respectively. }\end{array}$ & 0.1 & 190.3 & 34,718 \\
\hline Total & & \\
\hline
\end{tabular}

A_b

Operational Costs

\begin{tabular}{ll}
\hline \multicolumn{1}{c}{ Operation } & $\begin{array}{c}\text { Cost } \\
(\$)\end{array}$ \\
\hline Crush Concrete & 854 \\
Management Costs & 10,000 \\
Other Costs $\quad \begin{array}{l}\text { (demolishing +waste } \\
\text { packaging and disposal) }\end{array}$ & $3,245+2,200+0$ \\
\hline Total & $\$ 16,299$ \\
\end{tabular}




\section{Step 4. Develop Release Limits (Chapter 2, Section 2.4.1)}

\section{Alternative A (Cont.)}

Decontaminate the concrete material, dispose of all low-level waste (LLW), and crush and reuse the decontaminated material

A_c

\section{Transportation Costs}

\begin{tabular}{lcccc}
\hline \multicolumn{1}{c}{ Origin } & Destination & \# of Shipments & $\begin{array}{c}\text { Distance } \\
(\mathrm{km})\end{array}$ & Cost (\$) \\
\hline $\begin{array}{l}\text { Trickle filter } \\
\begin{array}{l}\text { DECON waste } \\
\text { (contaminated concrete) }\end{array}\end{array}$ & On-site & 1 & 20 & 349 \\
\hline Total & & & \\
\hline
\end{tabular}

$A_{-} d$

Transportation Impacts

\begin{tabular}{|c|c|c|c|}
\hline Destination & \# of Shipments & $\begin{array}{c}\text { Distance } \\
(\mathrm{km})\end{array}$ & $\begin{array}{c}\text { Dose } \\
\text { (person-rem) }\end{array}$ \\
\hline $\begin{array}{l}\text { Trickle filter } \\
\text { DECON waste } \\
\text { (contaminated concrete) }\end{array}$ & 1 & 20 & none \\
\hline Total & & & none \\
\hline
\end{tabular}




\section{Step 4. Develop Release Limits (Chapter 2, Section 2.4.1)}

\section{Alternative A (Cont.)}

Decontaminate the concrete material, dispose of all low-level waste (LLW), and crush and reuse the decontaminated material

$$
\mathrm{A}_{-} \mathrm{e}
$$

\section{Concrete Reuse-Impacts to a Construction Worker}

\begin{tabular}{lll}
\hline & $\begin{array}{c}\text { Concentration } \\
(\mathrm{pCi} / \mathrm{g})\end{array}$ & \\
\cline { 2 - 3 } Isotope & Maximum & Maximum \\
\hline Am-241 & 0.030 & $4.77 \mathrm{E}-05$ \\
Pu-238 & 0.0786 & $1.05 \mathrm{E}-04$ \\
Pu-239 & 0.027 & $3.99 \mathrm{E}-05$ \\
Ra-226 & 0.66 & $1.37 \mathrm{E}-02$ \\
$\mathrm{U}-234$ & 0.51 & $1.76 \mathrm{E}-04$ \\
$\mathrm{U}-235$ & 0.034 & $5.81 \mathrm{E}-05$ \\
$\mathrm{U}-238$ & 1.6 & $8.91 \mathrm{E}-02$ \\
Sr-90 & 0.81 & $5.17 \mathrm{E}-05$ \\
Cs-137 & 7.4 & $4.72 \mathrm{E}-02$ \\
Co-60 & 23.3 & $6.48 \mathrm{E}-01$ \\
Eu-152 & 0.059 & $7.45 \mathrm{E}-04$
\end{tabular}

Stop [If last alternative, proceed to Step 4, box 4c. If want to analyze another alternative, see Chapter 2, Section 2.4]

$8.00 \mathrm{E}-01$ 


\section{Step 4. Develop Release Limits (Chapter 2, Section 2.4.2)}

\section{Alternative B}

Crush and reuse the concrete without decontamination

\section{B1}

\begin{tabular}{|c|c|c|}
\hline \multirow[t]{5}{*}{ Operational Costs } & Operation & Cost $(\$)$ \\
\hline & Crush Concrete & 1,035 \\
\hline & Management Costs & 10,000 \\
\hline & $\begin{array}{l}\text { Other Costs } \\
\text { (demolishing) }\end{array}$ & 3,245 \\
\hline & Total & $\$ 14,280$ \\
\hline
\end{tabular}

B2

Transportation Costs

\section{Distance}

Origin

Destination

\# of Shipments

$(\mathrm{km})$

Cost $(\$)$

No transportation cost because concrete which is removed would be free released and would be used on-site.

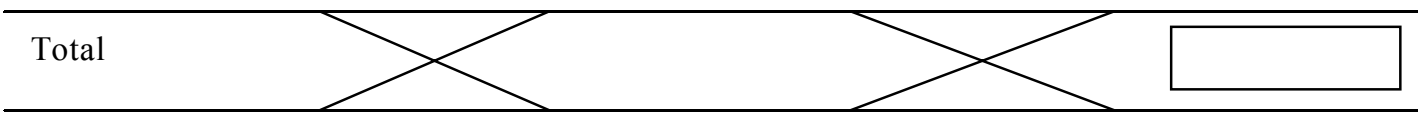




\section{Step 4. Develop Release Limits (Chapter 2, Section 2.4.2)}

\section{Alternative B (Cont.)}

Crush and reuse the concrete without decontamination

B3

\section{Transportation Impacts}

\begin{tabular}{ccccc}
\hline & & Distance & Dose \\
Origin & Destination & \# of Shipments & $(\mathrm{km})$ & (person-rem) \\
\hline
\end{tabular}

No transportation impacts because concrete which would be free released would be used on-site.

Total




\section{Step 4. Develop Release Limits (Chapter 2, Section 2.4.2)}

\section{Alternative B (Cont.)}

Crush and reuse the concrete without decontamination

B4

\section{Concrete Reuse-Impacts}

\begin{tabular}{lcc}
\hline & $\begin{array}{c}\text { Concentration } \\
(\mathrm{pCi} / \mathrm{g})\end{array}$ & \\
\cline { 2 - 3 } & Maximum & Dose (mrem) \\
\cline { 2 - 3 } Isotope & $6.37 \mathrm{E}-02$ & $1.15 \mathrm{E}-04$ \\
$\mathrm{Am}-241$ & $1.66 \mathrm{E}-01$ & $2.53 \mathrm{E}-04$ \\
$\mathrm{Pu}-238$ & $5.69 \mathrm{E}-02$ & $9.59 \mathrm{E}-05$ \\
$\mathrm{Pu}-239$ & $1.39 \mathrm{E}+00$ & $3.30 \mathrm{E}-02$ \\
$\mathrm{Ra}-226$ & $1.08 \mathrm{E}+00$ & $4.23 \mathrm{E}-04$ \\
$\mathrm{U}-234$ & $7.21 \mathrm{E}-02$ & $1.40 \mathrm{E}-04$ \\
$\mathrm{U}-235$ & $3.41 \mathrm{E}+00$ & $2.14 \mathrm{E}-01$ \\
$\mathrm{U}-238$ & $1.71 \mathrm{E}+00$ & $1.24 \mathrm{E}-04$ \\
$\mathrm{Sr}-90$ & $1.56 \mathrm{E}+01$ & $1.13 \mathrm{E}-02$ \\
$\mathrm{Cs}-137$ & $4.91 \mathrm{E}+01$ & $1.56 \mathrm{E}+00$ \\
$\mathrm{Co}-60$ & $1.24 \mathrm{E}-01$ & $1.79 \mathrm{E}-03$ \\
Eu-152 & & \\
& & \\
& & \\
\hline Total & & \\
\hline & & \\
\hline
\end{tabular}

Stop [If last alternative proceed to Step 4, box 4c. If want to analyze another alternative, see Chapter 2, Section 2.4] 


\section{Step 4. Develop Release Limits (Chapter 2, Section 2.4.3)}

\section{Alternative C}

Decontaminate the concrete material, dispose of all low-level waste (LLW), demolish the structure, and dispose of the concrete material at a nonradiological landfill or reuse as backfill material

$\mathrm{C}_{-} \mathrm{a}$

\section{Decontamination Method(s)}

\begin{tabular}{|c|c|c|c|}
\hline $\begin{array}{l}\text { Decontamination } \\
\text { Method }\end{array}$ & $\begin{array}{l}\text { Pecontamination } \\
\text { Factor }\end{array}$ & Waste Generation & $\operatorname{Cost}(\$)$ \\
\hline $\begin{array}{l}\text { Automated floor and wall } \\
\text { scabbling for floor and wal } \\
\text { contamination, respectivel }\end{array}$ & ly. & $190.3 \mathrm{ft}^{3}$ & $\$ 34,718$ \\
\hline Total & & $190.3 \mathrm{ft}^{3}$ & $\$ 34,718$ \\
\hline
\end{tabular}

$\mathrm{C}_{-} \mathrm{b}$

\section{Operational Costs}

\begin{tabular}{lc}
\multicolumn{1}{c}{ Operation } & Cost $(\$)$ \\
\hline Demolish Structure & 3,245 \\
Management Costs & 10,000 \\
Packaging/Container & 2,200 \\
Costs & \\
Other Costs & - \\
Disposal Costs & $0+2,727=2,727$ \\
\hline Total & $\$ 18,172$ \\
\hline
\end{tabular}




\section{Step 4. Develop Release Limits (Chapter 2, Section 2.4.3)}

\section{Alternative C (Cont.)}

Decontaminate the concrete material, dispose of all low-level waste (LLW), demolish the structure and dispose of the concrete material at a nonradiological landfill or reuse as backfill material

$\mathrm{C}_{-} \mathrm{c}$

Transportation Costs

\begin{tabular}{lcccc}
\hline \multicolumn{1}{c}{ Origin } & Destination & \# of Shipments & Distance $(\mathrm{km})$ & Cost $(\$)$ \\
\hline $\begin{array}{l}\text { Trickle filter } \\
\text { secondary waste } \\
\text { (contaminated concrete) }\end{array}$ & On-site & 1 & 20 & 349 \\
$\begin{array}{l}\text { Decontaminated } \\
\text { concrete }\end{array}$ & C\&D landfill & 1 & 4 & 42 \\
\hline Total & & & & $\$ 391$ \\
\hline
\end{tabular}

$\mathrm{C}_{-} \mathrm{d}$

Transportation Impacts

Dose

\begin{tabular}{ccccc} 
Origin & Destination & \# of Shipments & Distance $(\mathrm{km})$ & (person-rem) \\
\hline $\begin{array}{l}\text { Trickle filter } \\
\text { secondary waste } \\
\begin{array}{l}\text { Decontaminated } \\
\text { concrete }\end{array}\end{array}$ & On-site & 1 & 20 & none \\
\hline Total & 1 & 4 & $9.0 \mathrm{E}-07$ \\
\hline
\end{tabular}




\section{Step 4. Develop Release Limits (Chapter 2, Section 2.4.3)}

\section{Alternative C (Cont.)}

Decontaminate the concrete material, dispose of all low-level waste (LLW), demolish the structure, and dispose of the concrete material at a nonradiological landfill or reuse as backfill material

C_e

\section{Concrete Disposal}

\begin{tabular}{l}
$\begin{array}{c}\text { Concentration } \\
(\mathrm{pCi})\end{array} \quad$ Dose (mrem) \\
\hline
\end{tabular}

\begin{tabular}{clll} 
Receptor & Isotope & Maximum & Maximum \\
\hline \multirow{2}{*}{ Driver } & & & \\
& Am-241 & $2.58 \mathrm{E}+06$ & $2.37 \mathrm{E}-09$ \\
& Pu-238 & $6.71 \mathrm{E}+06$ & $4.56 \mathrm{E}-12$ \\
& Pu-239 & $2.30 \mathrm{E}+06$ & $4.61 \mathrm{E}-11$ \\
& Ra-226 & $5.6 \mathrm{E}+07$ & $5.18 \mathrm{E}-05$ \\
& $\mathrm{U}-234$ & $.39 \mathrm{E}+07$ & $6.14 \mathrm{E}-10$ \\
& $\mathrm{U}-235$ & $2.92 \mathrm{E}+06$ & $1.75 \mathrm{E}-07$ \\
& $\mathrm{U}-238$ & $1.38 \mathrm{E}+08$ & $1.44 \mathrm{E}-06$ \\
& Sr-90 & $6.92 \mathrm{E}+07$ & 0.00 \\
& CS- -137 & $6.32 \mathrm{E}+08$ & $1.77 \mathrm{E}-04$ \\
& Co-60 & $1.99 \mathrm{E}+09$ & $2.63 \mathrm{E}-03$ \\
& Eu-152 & $5.04 \mathrm{E}+06$ & $2.82 \mathrm{E}-06$ \\
& & & \\
\hline
\end{tabular}

$2.86 \mathrm{E}-03$

\begin{tabular}{llll}
\hline Landfill & Am-241 & $2.58 \mathrm{E}+06$ & $1.68 \mathrm{E}-05$ \\
Worker & Pu-238 & $6.71 \mathrm{E}+06$ & $3.82 \mathrm{E}-05$ \\
& Pu-239 & $2.30 \mathrm{E}+06$ & $1.45 \mathrm{E}-05$ \\
& Ra-226 & $5.63 \mathrm{E}+07$ & $2.65 \mathrm{E}-05$ \\
& $\mathrm{U}-234$ & $4.39 \mathrm{E}+07$ & $8.34 \mathrm{E}-05$ \\
& $\mathrm{U}-235$ & $2.92 \mathrm{E}+06$ & $6.13 \mathrm{E}-05$ \\
& $\mathrm{U}-238$ & $1.38 \mathrm{E}+08$ & $2.49 \mathrm{E}-04$ \\
& Sr-90 & $6.92 \mathrm{E}+07$ & $1.32 \mathrm{E}-06$ \\
& Cs-137 & $6.32 \mathrm{E}+08$ & $8.84 \mathrm{E}-04$ \\
& Co-60 & $1.99 \mathrm{E}+09$ & $1.33 \mathrm{E}-02$ \\
& Eu-152 & $5.04 \mathrm{E}+06$ & $1.46 \mathrm{E}-05$ \\
\hline \multirow{2}{*}{ Total } & & \\
& & & \\
\end{tabular}




\section{Step 4. Develop Release Limits (Chapter 2, Section 2.4.3)}

\section{Alternative C (Cont.)}

Decontaminate the concrete material, dispose of all low-level waste (LLW), demolish the structure, and dispose of the concrete material at a nonradiological landfill or reuse as backfill material

$\mathrm{C} \_\mathrm{f}$

Disposal-Future Resident

\begin{tabular}{lll}
\hline & $\begin{array}{c}\text { Concentration } \\
(\mathrm{pCi} / \mathrm{g})\end{array}$ & \\
\cline { 2 - 3 } \multicolumn{1}{c}{ Isotope } & Maximum & Dose (mrem) \\
\hline Am-241 & 0.030 & $1.88 \mathrm{E}-03$ \\
$\mathrm{Pu}-238$ & 0.0786 & $1.66 \mathrm{E}-04$ \\
$\mathrm{Pu}-239$ & 0.027 & $6.34 \mathrm{E}-05$ \\
$\mathrm{Ra}-226$ & 0.66 & $2.47 \mathrm{E}-01$ \\
$\mathrm{U}-234$ & 0.51 & $2.37 \mathrm{E}-04$ \\
$\mathrm{U}-235$ & 0.034 & $2.75 \mathrm{E}-04$ \\
$\mathrm{U}-238$ & 1.6 & $4.60 \mathrm{E}-03$ \\
Sr-90 & 0.81 & $2.16 \mathrm{E}-02$ \\
$\mathrm{Cs}-137$ & 7.4 & $8.97 \mathrm{E}-02$ \\
Co-60 & 23.3 & $1.10 \mathrm{E}+00$ \\
Eu-152 & 0.059 & $1.21 \mathrm{E}-03$ \\
& & \\
& & \\
\hline Total & & \\
\hline
\end{tabular}

Stop [If last alternative, proceed to Step 4, box 4c. If want to analyze another alternative, see Chapter 2, Section 2.4] 


\section{Step 4. Develop Release Limits (Chapter 2, Section 2.4.4)}

\section{Alternative D}

Demolish the structure and dispose of the concrete material at a nonradiological landfill or reuse as backfill material

$\mathrm{D}_{-} \mathrm{a}$

\begin{tabular}{|c|c|c|}
\hline \multirow[t]{7}{*}{ Operational Costs } & Operation & $\begin{array}{l}\text { Cost } \\
(\$)\end{array}$ \\
\hline & Demolish Structure & 3,245 \\
\hline & Management Costs & 10,000 \\
\hline & $\begin{array}{l}\text { Packaging/Container } \\
\text { Costs }\end{array}$ & - \\
\hline & Disposal Costs & 3,109 \\
\hline & Other Costs & - \\
\hline & Total & $\$ 16,354$ \\
\hline
\end{tabular}




\section{Step 4. Develop Release Limits (Chapter 2, Section 2.4.4)}

\section{Alternative D (Cont.)}

Demolish the structure, and dispose of the concrete material at a nonradiological landfill or reuse as backfill material

D_b

\section{Transportation Costs}

\begin{tabular}{llccc}
\hline \multicolumn{1}{c}{ Origin } & Destination & \# of Shipments & Distance $(\mathrm{km})$ & Cost $(\$)$ \\
\hline $\begin{array}{l}\text { Trickle filter } \\
\text { crushed concrete }\end{array}$ & C\&D landfill & 1 & 4 & 48 \\
\hline Total & & & \\
\hline
\end{tabular}

$\mathrm{D}_{-} \mathrm{c}$

Transportation Impacts

Dose

\begin{tabular}{lcccc} 
Origin & Destination & \# of Shipments & Distance $(\mathrm{km})$ & (person-rem) \\
\hline $\begin{array}{l}\text { Trickle filter } \\
\text { crushed concrete }\end{array}$ & C\&D landfill & 1 & 4 & $2.17 \mathrm{E}-06$ \\
& & & $2.17 \mathrm{E}-06$ \\
\hline
\end{tabular}




\section{Step 4. Develop Release Limits (Chapter 2, Section 2.4.4)}

\section{Alternative D (Cont.)}

Demolish the structure, and dispose of the concrete material at a nonradiological landfill or reuse as backfill material

D_d

\section{Concrete Disposal}

\begin{tabular}{|c|c|c|c|}
\hline \multirow[b]{2}{*}{ Receptor } & \multirow[b]{2}{*}{ Isotope } & $\begin{array}{l}\text { Concentration } \\
\qquad(\mathrm{pCi})\end{array}$ & Dose (mrem) \\
\hline & & Maximum & Maximum \\
\hline Driver & $\begin{array}{l}\text { Am-241 } \\
\text { Pu-238 } \\
\text { Pu-239 } \\
\text { Ra-226 } \\
\text { U-234 } \\
\text { U-235 } \\
\text { U-238 } \\
\text { Sr-90 } \\
\text { Cs-137 } \\
\text { Co-60 } \\
\text { Eu-152 }\end{array}$ & $\begin{array}{l}6.20 \mathrm{E}+06 \\
1.61 \mathrm{E}+07 \\
5.54 \mathrm{E}+06 \\
1.35 \mathrm{E}+08 \\
1.05 \mathrm{E}+08 \\
7.02 \mathrm{E}+06 \\
3.32 \mathrm{E}+08 \\
1.66 \mathrm{E}+08 \\
1.52 \mathrm{E}+09 \\
4.78 \mathrm{E}+09 \\
1.21 \mathrm{E}+07\end{array}$ & $\begin{array}{l}5.70 \mathrm{E}-09 \\
1.10 \mathrm{E}-11 \\
1.11 \mathrm{E}-10 \\
1.25 \mathrm{E}-04 \\
1.48 \mathrm{E}-09 \\
4.21 \mathrm{E}-07 \\
3.46 \mathrm{E}-06 \\
0.0 \\
4.25 \mathrm{E}-04 \\
6.31 \mathrm{E}-03 \\
6.78 \mathrm{E}-06\end{array}$ \\
\hline Total & & & 6.87E-03 \\
\hline $\begin{array}{l}\text { Landfill } \\
\text { Worker }\end{array}$ & $\begin{array}{l}\text { Am-241 } \\
\text { Pu-238 } \\
\text { Pu-239 } \\
\text { Ra-226 } \\
\text { U-234 } \\
\text { U-235 } \\
\text { U-238 } \\
\text { Sr-90 } \\
\text { Cs-137 } \\
\text { Co-60 } \\
\text { Eu-152 } \\
\end{array}$ & $\begin{array}{l}6.20 \mathrm{E}+06 \\
1.61 \mathrm{E}+07 \\
5.54 \mathrm{E}+06 \\
1.35 \mathrm{E}+08 \\
1.05 \mathrm{E}+08 \\
7.02 \mathrm{E}+06 \\
3.32 \mathrm{E}+08 \\
1.66 \mathrm{E}+08 \\
1.52 \mathrm{E}+09 \\
4.78 \mathrm{E}+09 \\
1.21 \mathrm{E}+07\end{array}$ & $\begin{array}{l}4.03 \mathrm{E}-05 \\
9.19 \mathrm{E}-05 \\
3.49 \mathrm{E}-05 \\
6.37 \mathrm{E}-04 \\
2.00 \mathrm{E}-04 \\
1.47 \mathrm{E}-05 \\
5.98 \mathrm{E}-04 \\
3.16 \mathrm{E}-06 \\
2.13 \mathrm{E}-03 \\
3.20 \mathrm{E}-02 \\
3.51 \mathrm{E}-05 \\
\end{array}$ \\
\hline Total & & & $3.58 \mathrm{E}-02$ \\
\hline
\end{tabular}




\section{Step 4. Develop Release Limits (Chapter 2, Section 2.4.4)}

\section{Alternative D (Cont.)}

Demolish the structure, and dispose of the concrete material at a nonradiological landfill or reuse as backfill material

D_e

Disposal-Future Resident

\begin{tabular}{lcl}
\hline & $\begin{array}{c}\text { Concentration } \\
(\mathrm{pCi} / \mathrm{g})\end{array}$ & \\
\cline { 2 - 2 } Isotope & Maximum & Dose (mrem) \\
\hline Am-241 & $6.37 \mathrm{E}-02$ & \\
$\mathrm{Pu}-238$ & $1.66 \mathrm{E}-01$ & $4.52 \mathrm{E}-03$ \\
$\mathrm{Pu}-239$ & $5.69 \mathrm{E}-02$ & $3.98 \mathrm{E}-04$ \\
$\mathrm{Ra}-226$ & $1.39 \mathrm{E}+00$ & $1.52 \mathrm{E}-04$ \\
$\mathrm{U}-234$ & $1.08 \mathrm{E}+00$ & $5.93 \mathrm{E}-01$ \\
$\mathrm{U}-235$ & $7.21 \mathrm{E}-02$ & $5.70 \mathrm{E}-04$ \\
$\mathrm{U}-238$ & $3.41 \mathrm{E}+00$ & $6.62 \mathrm{E}-04$ \\
Sr-90 & $1.71 \mathrm{E}+00$ & $1.11 \mathrm{E}-02$ \\
Cs-137 & $1.56 \mathrm{E}+01$ & $5.19 \mathrm{E}-02$ \\
Co-60 & $4.91 \mathrm{E}+01$ & $2.16 \mathrm{E}-01$ \\
Eu-152 & $1.24 \mathrm{E}-01$ & $2.64 \mathrm{E}+00$ \\
& & $2.92 \mathrm{E}-03$ \\
& & \\
\hline Total & & \\
\hline
\end{tabular}

Stop [If last alternative, proceed to Step 4, box 4c. If want to analyze another alternative, see Chapter 2, Section 2.4] 


\section{Step 4. Develop Release Limits (Chapter 2, Section 2.4.5)}

\section{Alternative E}

Demolish the structure and dispose of the concrete material at a low-level waste (LLW) facility

E_a

\begin{tabular}{|c|c|c|}
\hline \multirow[t]{6}{*}{ Operational Costs } & Operation & $\begin{array}{c}\text { Cost } \\
(\$)\end{array}$ \\
\hline & Demolish Structure & 3,245 \\
\hline & Management Costs & 10,000 \\
\hline & $\begin{array}{l}\text { Packaging/Container } \\
\text { Costs }\end{array}$ & 25,482 \\
\hline & Disposal Costs & 0 \\
\hline & Total & $\$ 38,727$ \\
\hline
\end{tabular}




\section{Step 4. Develop Release Limits (Chapter 2, Section 2.4.5)}

\section{Alternative E (Cont.)}

Demolish the structure and dispose the concrete material at a low-level waste facility

E_b

\section{Transportation Costs}

\begin{tabular}{lllll}
\hline \multicolumn{1}{c}{ Origin } & Destination & \# of Shipments & $\begin{array}{c}\text { Distance } \\
(\mathrm{km})\end{array}$ & $\begin{array}{c}\text { Cost } \\
(\$)\end{array}$ \\
\hline $\begin{array}{l}\text { Trickle filter } \\
\text { contaminated } \\
\text { concrete }\end{array}$ & Envirocare & 6 & 600 & 4,816 \\
\hline Total & & & \\
\hline
\end{tabular}

E_c

Transportation Impacts

\begin{tabular}{lllll}
\hline \multicolumn{1}{c}{ Origin } & Destination & \# of Shipments & $\begin{array}{c}\text { Distance } \\
(\mathrm{km})\end{array}$ & $\begin{array}{c}\text { Dose } \\
\text { (person-rem) }\end{array}$ \\
\hline $\begin{array}{l}\text { Trickle filter } \\
\text { contaminated } \\
\begin{array}{l}\text { concrete } \\
\text { Total }\end{array}\end{array}$ & Envirocare & 6 & 600 & $3.25 \mathrm{E}-04$ \\
\hline
\end{tabular}

Stop [If last alternative, proceed to Step 4, box 4c. If want to analyze another alternative, see Chapter 2, Section 2.4] 


\section{Step 4. Develop Release Limits (Chapter 2, Section 2.4.6)}

\section{Alternative F}

Decontaminate and reuse the building as an office

$\mathrm{F}_{-} \mathrm{a}$

\section{Decontamination Method(s)}

\begin{tabular}{cccc}
\hline $\begin{array}{c}\text { Decontamination } \\
\text { Method }\end{array}$ & $\begin{array}{c}\text { Decontamination } \\
\text { Factor }\end{array}$ & $\begin{array}{c}\text { Waste Generation } \\
\left(\mathrm{ft}^{3}\right)\end{array}$ & $\begin{array}{c}\text { Cost } \\
(\$)\end{array}$ \\
\hline
\end{tabular}

Total

F_b

Transportation Costs

\begin{tabular}{|c|c|c|c|c|}
\hline Origin & Destination & \# of Shipments & $\begin{array}{c}\text { Distance } \\
(\mathrm{km})\end{array}$ & $\begin{array}{c}\text { Cost } \\
(\$)\end{array}$ \\
\hline Total & & & & \\
\hline
\end{tabular}




\section{Step 4. Develop Release Limits (Chapter 2, Section 2.4.6)}

\section{Alternative F (Cont.)}

Decontaminate and reuse the building as an office

$\mathrm{F}_{-} \mathrm{c}$

Transportation Impacts

\begin{tabular}{cccc}
\hline & & Distance \\
Origin & Destination & \# of Shipments & $\begin{array}{c}\text { Dose } \\
\text { (person-rem) }\end{array}$ \\
\hline
\end{tabular}




\section{Step 4. Develop Release Limits (Chapter 2, Section 2.4.6)}

\section{Alternative F (Cont.)}

Decontaminate and reuse the building as an office

F_d

Concrete Reuse-Impacts

\begin{tabular}{|c|c|c|c|c|}
\hline \multirow[b]{2}{*}{ Isotope } & \multicolumn{2}{|c|}{$\begin{array}{c}\text { Concentration } \\
\left(\mathrm{pCi} / \mathrm{g} \text { or } \mathrm{DPM} / 100 \mathrm{~cm}^{2}\right)\end{array}$} & \multicolumn{2}{|c|}{ Dose (mrem) } \\
\hline & Average & Maximum & Average & Maximum \\
\hline
\end{tabular}

$\square \longdiv { \square }$

Stop [If last alternative, proceed to Step 4, box 4c. If want to analyze another alternative, see Chapter 2, Section 2.4] 


\section{Step 4. Develop Release Limits (Chapter 2, Section 2.4.7)}

\section{Alternative G}

The concrete structure will be demolished and entombed on-site

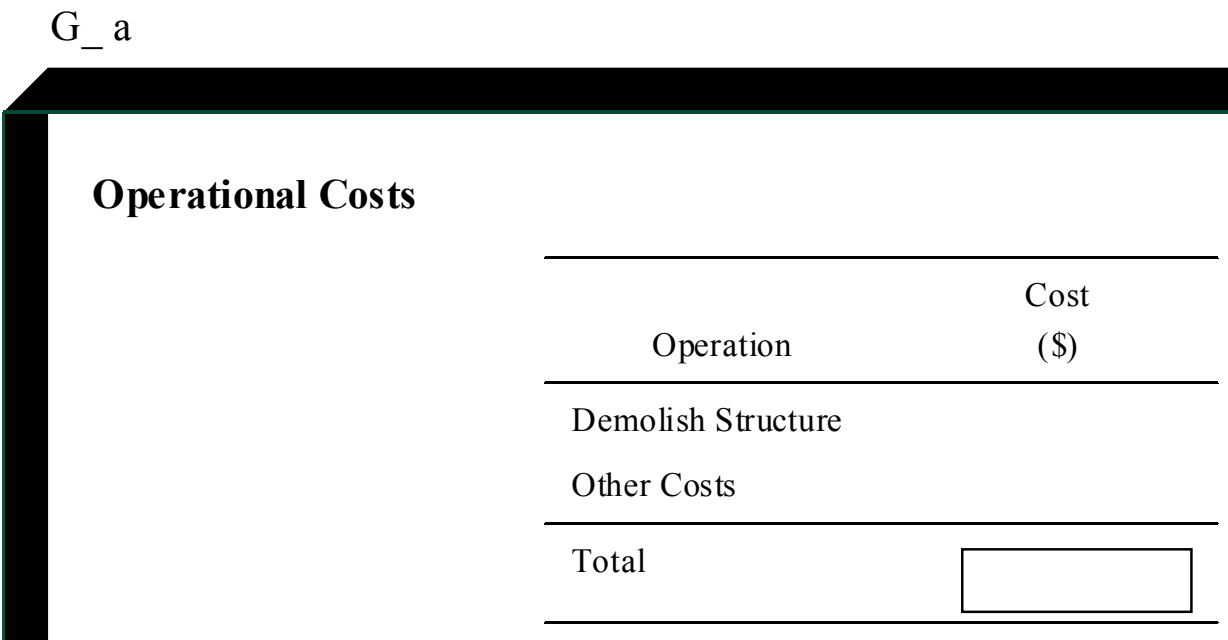


Step 4. Develop Release Limits (Chapter 2, Section 2.4.7)

\section{Alternative G (Cont.)}

The concrete structure will be demolished and entombed on-site

G_b

Disposal-Future Resident

\begin{tabular}{|c|c|c|c|c|}
\hline \multirow[b]{2}{*}{ Isotope } & \multicolumn{2}{|c|}{$\begin{array}{c}\text { Concentration } \\
\left(\mathrm{pCi} / \mathrm{g} \text { or } \mathrm{DPM} / 100 \mathrm{~cm}^{2}\right)\end{array}$} & \multicolumn{2}{|c|}{ Dose (mrem) } \\
\hline & Average & Maximum & Average & Maximum \\
\hline
\end{tabular}

Total 


\section{Step 4. Develop Release Limits (Chapter 2, Section 2.4.8)}

4c Summary of Alternatives

Summary of Costs/Radiological Impacts

Costs (\$)

Alternative + Operational
Decontamination

A

B

$\mathrm{C}$

D $\quad 16,354$

E

38,727

$34,718+16,299$

14,280

None

Dose (person-rem or mrem)

\begin{tabular}{|c|c|c|}
\hline & & Future \\
\hline Population Driver & Worker & Resident \\
\hline
\end{tabular}

Transportation

391

9.01E-07 2.86E-03

$1.49 \mathrm{E}-02$

2.17E-06 6.87E-03

$3.58 \mathrm{E}-02$

3.53

E $\quad 38,727 \quad 2,096 \quad$ none




\section{Step 4. Develop Release Limits (Chapter 2, Section 2.4.9)}

4d Proposed Authorized Release Limits

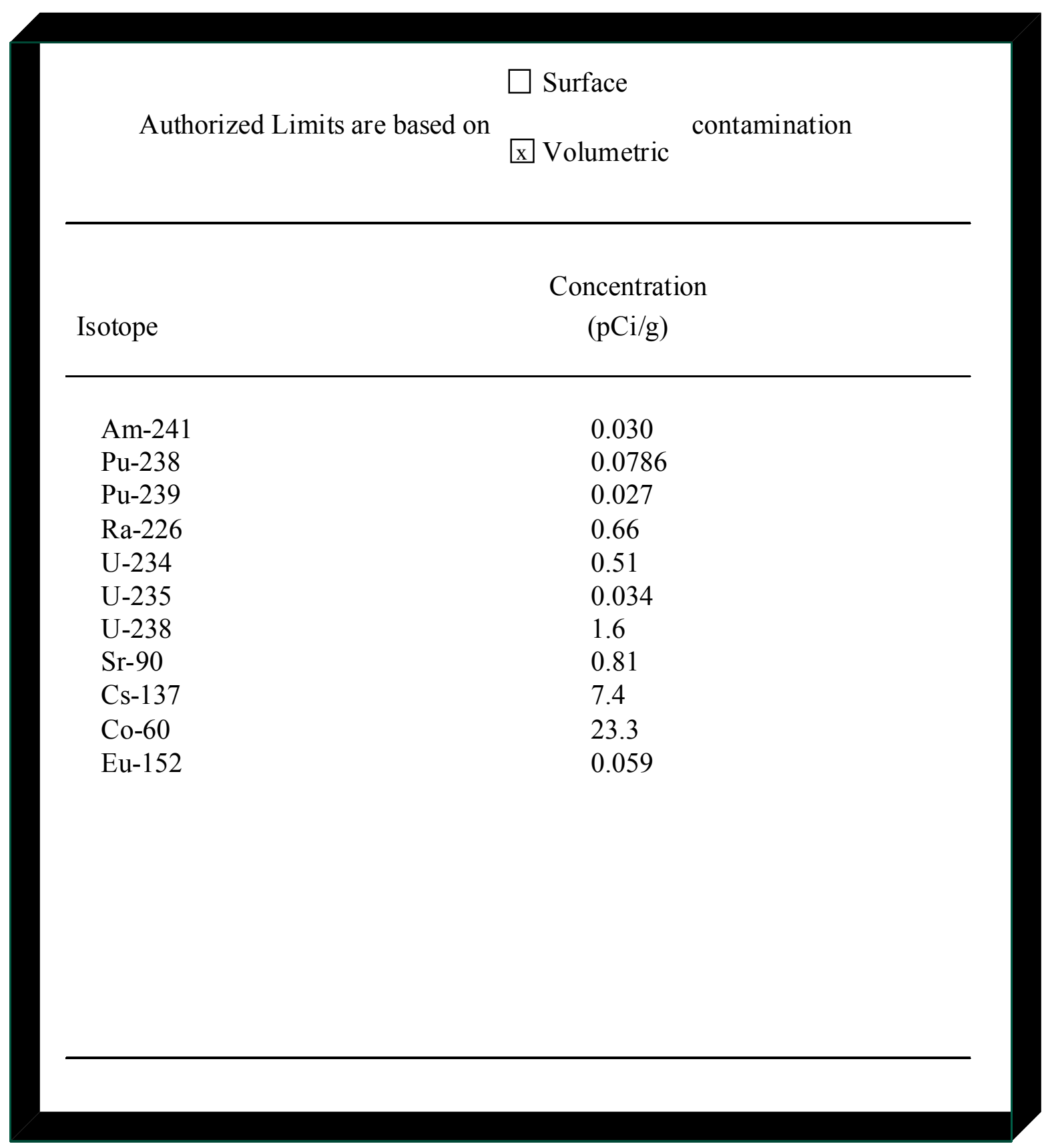

Go to Next Page 


\section{Step 5. Compile and Submit Application for DOE Operations} Approval (Chapter 2, Sections 2.4.9 and 2.5)

5a Restrictions on Use Following Release (if applicable)

Decontaminate the concrete material at the trickle filter structure, dispose of all low-level waste (LLW), and crush and reuse the decontaminated concrete on-site for constructing road base. Before reusing, make sure decontaminated concrete meets the authorized release limits. If the concrete can not be used on-site, send it to sanitary landfill. 
Step 5. Compile and Submit Application for DOE Operations Approval (Chapter 2, Section 2.5)

$5 b$

Comments/recommendations by other state or federal agencies (attach documents) 
Step 5. Compile and Submit Application for DOE Operations Approval (Chapter 2, Section 2.8)

Survey Protocols (attach applicable documents) 
APPENDIX C:

GENERIC COST AND DOSE ANALYSIS FOR CONCRETE DISPOSITION FROM TRICKLE FILTER STRUCTURE 


$$
\text { C-2 }
$$




\section{APPENDIX C:}

\section{GENERIC COST AND DOSE ANALYSIS FOR CONCRETE DISPOSITION FROM TRICKLE FILTER STRUCTURE}

Appendix $\mathrm{C}$ provides the cost and dose analysis for disposition alternatives for trickle filter concrete for a generic case. Table C.1 lists all cost parameters used in the analysis, Table C.2 provides the cost calculations for decontamination, demolition, crushing, waste packaging, shipment, transportation, and disposal. Table C.3 lists the unit dose factors from Arnish et al. (2000) for radionuclides found at Central Facility Area 691. Table C.4 gives the observed radionuclide concentrations in the sediment sample from the trickle filter structure. Tables C.5 and C.7 provide the concrete residual radionuclide concentrations used for calculations after decontamination (Table C.5) and when no decontamination was done at the trickle filter structure (Table C.7). Tables C.6 and C.8 give the estimated doses to different receptors after decontamination (Table C.6) and when no decontamination was done (Table C.8). 
TABLE C.1 Cost Assumptions for Trickle Filter Disposal Alternatives for a Generic Case

\begin{tabular}{|c|c|}
\hline Cost Parameters & Value \\
\hline LLW disposal cost, $\$ / \mathrm{ft}^{3}$ & 65 \\
\hline Cost to transport C\&D waste, $\$ / \mathrm{yd}^{3} / \mathrm{mi}^{2}$ & 0.15 \\
\hline Disposal cost of $C \& D$ waste, $\$ / y^{3}$ & 25 \\
\hline Distance to LLW facility, mi (km) & $327(600)^{\mathrm{a}}$ \\
\hline Distance to C\&D facility, mi $(\mathrm{km})$ & $20(40)^{\mathrm{a}}$ \\
\hline Concrete crushing cost, $\$ / \mathrm{MT}$ & 23 \\
\hline D\&D equipment lifetime floor (wall), yr & $10(10)$ \\
\hline D\&D equipment interest rate, $\%$ & 8 \\
\hline D\&D equipment use time floor (wall), $\mathrm{h}$ & $168(168)$ \\
\hline Demolishing cost, $\$ / \mathrm{ft}^{2}$ & 1 \\
\hline Floor decon equipment purchase cost, $\$$ & 100,000 \\
\hline Wall decon equipment purchase cost, \$ & 200,000 \\
\hline DECON worker hourly cost, $\$$ & 50 \\
\hline Floor DECON production rate, $\mathrm{ft}^{2} / \mathrm{h} /$ pass & 200 \\
\hline Wall DECON production rate, $\mathrm{ft}^{2} / \mathrm{h} /$ pass & 150 \\
\hline Floor DECON process cost, $\$ / \mathrm{ft}^{2} /$ pass & 5 \\
\hline Wall DECON process cost, $\$ / \mathrm{ft}^{2} /$ pass & 10 \\
\hline Floor removal rate, in./pass & 0.5 \\
\hline Wall removal rate, in./pass & 0.25 \\
\hline Concrete density, $\mathrm{g} / \mathrm{cm}^{3}$ & 2.2 \\
\hline Volume to mass conversion, $\mathrm{MT} / \mathrm{ft}^{3}$ & 0.06297 \\
\hline Container cost per container for 55 -gal drum, $\$$ & 50 \\
\hline Container cost per container for B-25 type, $\$$ & 790 \\
\hline Unit loading cost for 55 -gal drum, $\$$ & 100 \\
\hline Unit loading cost for B-25 type container, $\$$ & 160 \\
\hline Fixed cost per shipment for 55 -gal drums, $\$$ & 880 \\
\hline Fixed cost per shipment for B-25 type containers, $\$$ & \\
\hline Cost per shipment-mile for 55 -gal drums, $\$$ & 4 \\
\hline Cost per shipment-mile for B-25 type container, $\$$ & 1.43 \\
\hline Total concrete volume of Trickle filter, $\mathrm{ft}^{3}$ & 1546 \\
\hline Floor area, $\mathrm{ft}^{2}$ & 1960 \\
\hline Wall area, $\mathrm{ft}^{2}$ & 1280 \\
\hline
\end{tabular}

a For sake of conservatism in analysis, distance values have been rounded up when converted from miles to kilometers. 
TABLE C.2 Cost Calculations for Decontamination, Demolition, Packaging, Transportation, and Disposal

\begin{tabular}{|c|c|}
\hline Component & Value \\
\hline \multicolumn{2}{|l|}{ Decontamination Cost Calculations } \\
\hline Floor DECON depth, in & 1 \\
\hline Wall DECON depth, in & 0.25 \\
\hline Waste for floor decon, $\mathrm{ft}^{3}$ & 164 \\
\hline Waste for wall decon, $\mathrm{ft}^{3}$ & 27 \\
\hline Total waste generated, $\mathrm{ft}^{3}$ & 190 \\
\hline Amortization cost for floor equipment, $\$ / \mathrm{h}$ & 1.70 \\
\hline Amortization cost for wall equipment, $\$ / \mathrm{h}$ & 3.40 \\
\hline Decon cost (floors), $\$$ & 20,900 \\
\hline Decon cost (walls), $\$$ & 13,800 \\
\hline Total decontamination cost, $\$$ & 34,700 \\
\hline Demolition Cost for Entire Concrete Building, \$ & 3,245 \\
\hline \multicolumn{2}{|l|}{ Crushing Cost } \\
\hline Entire concrete building, $\$$ & 2,239 \\
\hline Remaining building (after decontamination), $\$$ & 1,964 \\
\hline \multicolumn{2}{|l|}{ Fines Generated } \\
\hline Entire concrete building, MT & 29 \\
\hline Remaining building after decontamination, MT & 26 \\
\hline \multicolumn{2}{|l|}{ Decon Waste Packaging } \\
\hline Number of 55 gallon drums & 2 \\
\hline Number of B-25 type boxes & 2 \\
\hline LLW packaging cost, $\$$ & 2,200 \\
\hline \multicolumn{2}{|l|}{ Packaging for $L L W$} \\
\hline Number of B-25 type boxes (entire structure to LLW ) & 27 \\
\hline Packaging cost, $\$$ & 25,482 \\
\hline \multicolumn{2}{|l|}{ Shipments } \\
\hline Number of shipments (entire structure to LLW) & 6 \\
\hline Number of shipments (decontamination waste to LLW) & 1 \\
\hline \multicolumn{2}{|l|}{ Transportation Costs } \\
\hline Entire structure to LLW, $\$$ & 4,816 \\
\hline Decontaminated waste to LLW, \$ & 803 \\
\hline Decontaminated structure to $\mathrm{C} \& \mathrm{D}, \$$ & 151 \\
\hline Entire structure to $\mathrm{C} \& \mathrm{D}, \$$ & 172 \\
\hline \multicolumn{2}{|l|}{ Disposal Costs } \\
\hline Entire structure to LLW, \$ & 100,490 \\
\hline Entire structure to $\mathrm{C} \& \mathrm{D}, \$$ & 1,431 \\
\hline Decontaminated structure to $\mathrm{C} \& \mathrm{D}, \$$ & 1,255 \\
\hline LLW to LLW site, $\$$ & 12,367 \\
\hline
\end{tabular}


TABLE C.3 Unit Dose Factors from Concrete Protocol Report for Radionuclides Found at Central Facility Area 691

\begin{tabular}{|c|c|c|c|c|c|}
\hline Radionuclide & $\begin{array}{c}\text { Landfill } \\
\text { Worker } \\
\text { (mrem/pCi) }\end{array}$ & $\begin{array}{c}\text { Burial Dose } \\
\text { (mrem/yr per pCi/g } \\
\text { per ton concrete) }\end{array}$ & $\begin{array}{c}\text { Driver Dose } \\
(\mathrm{mrem} / \mathrm{pCi} / \mathrm{km})\end{array}$ & $\begin{array}{c}\text { Collective } \\
\text { Dose (person- } \\
\text { rem } / \mathrm{pCi} / \mathrm{km}) \\
\end{array}$ & $\begin{array}{c}\text { Construction } \\
\text { Worker } \\
\text { (mrem/yr/pCi/g/ton) }\end{array}$ \\
\hline Am-241 & $6.50 \mathrm{E}-12$ & 7.29E-04 & $2.30 \mathrm{E}-16$ & $3.41 \mathrm{E}-20$ & $1.85 \mathrm{E}-05$ \\
\hline Pu-238 & $5.70 \mathrm{E}-12$ & $2.47 \mathrm{E}-05$ & $1.70 \mathrm{E}-19$ & $1.78 \mathrm{E}-23$ & $1.57 \mathrm{E}-05$ \\
\hline Pu-239 & $6.30 \mathrm{E}-12$ & $2.75 \mathrm{E}-05$ & $5.00 \mathrm{E}-18$ & $1.54 \mathrm{E}-21$ & $1.73 \mathrm{E}-05$ \\
\hline $\mathrm{Ra}-226+\mathrm{D}$ & $4.70 \mathrm{E}-12$ & $4.38 \mathrm{E}-03$ & $2.30 \mathrm{E}-13$ & $7.22 \mathrm{E}-17$ & $2.44 \mathrm{E}-04$ \\
\hline U-234 & $1.90 \mathrm{E}-12$ & $5.40 \mathrm{E}-06$ & $3.50 \mathrm{E}-18$ & 7.62E-22 & 4.01E-06 \\
\hline $\mathrm{U}-235+\mathrm{D}$ & $2.10 \mathrm{E}-12$ & $9.43 \mathrm{E}-05$ & $1.50 \mathrm{E}-14$ & $4.61 \mathrm{E}-18$ & $1.99 \mathrm{E}-05$ \\
\hline $\mathrm{U}-238+\mathrm{D}$ & $1.80 \mathrm{E}-12$ & 3.33E-05 & $2.60 \mathrm{E}-15$ & $7.82 \mathrm{E}-19$ & $6.44 \mathrm{E}-04$ \\
\hline Sr-90 & $1.90 \mathrm{E}-14$ & $3.12 \mathrm{E}-04$ & $0.00 \mathrm{E}+00$ & $0.00 \mathrm{E}+00$ & 7.47E-07 \\
\hline Cs $-137+\mathrm{D}$ & $1.40 \mathrm{E}-12$ & $1.42 \mathrm{E}-04$ & $7.00 \mathrm{E}-14$ & $2.21 \mathrm{E}-17$ & 7.47E-05 \\
\hline Сo-60 & $6.70 \mathrm{E}-12$ & $5.53 \mathrm{E}-04$ & $3.30 \mathrm{E}-13$ & $1.04 \mathrm{E}-16$ & $3.26 \mathrm{E}-04$ \\
\hline Eu-152 & $2.90 \mathrm{E}-12$ & $2.41 \mathrm{E}-04$ & $1.40 \mathrm{E}-13$ & $4.41 \mathrm{E}-17$ & $1.48 \mathrm{E}-04$ \\
\hline
\end{tabular}

TABLE C.4 Measured Radionuclide Concentration in the Sediment Sample from the Trickle Filter Structure

\begin{tabular}{lc}
\hline Radionuclides & Sediment $(\mathrm{pCi} / \mathrm{g})$ \\
\hline & \\
$\mathrm{Am}-241$ & 0.302 \\
$\mathrm{Pu}-238$ & 0.786 \\
$\mathrm{Pu}-239$ & 0.27 \\
$\mathrm{Ra}-226$ & 6.6 \\
$\mathrm{U}-234$ & 5.14 \\
$\mathrm{U}-235$ & 0.342 \\
$\mathrm{U}-238$ & 16.2 \\
$\mathrm{Sr}-90$ & 8.11 \\
$\mathrm{Cs}-137$ & 74 \\
$\mathrm{Co}-60$ & 233 \\
Eu-152 & 0.59 \\
\hline
\end{tabular}


TABLE C.5 Residual Radionuclide Concentration in Trickle Filter Concrete after Decontaminationa

\begin{tabular}{lccc}
\hline & $\begin{array}{c}\text { Trickle Filter's } \\
\text { Decontaminated Concrete } \\
\text { Concentration (pCi/g) }\end{array}$ & $\begin{array}{c}\text { Total Activity in 85.36 Tons } \\
\text { Trickle Filter Decontaminated } \\
\text { Concrete (pCi) }\end{array}$ & $\begin{array}{c}\text { Total Activity in 11.99 } \\
\text { Tons of Trickle Filter } \\
\text { Waste (pCi) }\end{array}$ \\
\hline Am-241 & $3.02 \mathrm{E}-02$ & $2.58 \mathrm{E}+06$ & $3.62 \mathrm{E}+06$ \\
Pu-238 & $7.86 \mathrm{E}-02$ & $6.71 \mathrm{E}+06$ & $9.42 \mathrm{E}+06$ \\
Pu-239 & $2.70 \mathrm{E}-02$ & $2.30 \mathrm{E}+06$ & $3.24 \mathrm{E}+06$ \\
Ra-226 & $6.60 \mathrm{E}-01$ & $5.63 \mathrm{E}+07$ & $7.91 \mathrm{E}+07$ \\
$\mathrm{U}-234$ & $5.14 \mathrm{E}-01$ & $4.39 \mathrm{E}+07$ & $6.16 \mathrm{E}+07$ \\
U-235 & $3.42 \mathrm{E}-02$ & $2.92 \mathrm{E}+06$ & $4.10 \mathrm{E}+06$ \\
U-238 & $1.62 \mathrm{E}+00$ & $1.38 \mathrm{E}+08$ & $1.94 \mathrm{E}+08$ \\
Sr-90 & $8.11 \mathrm{E}-01$ & $6.92 \mathrm{E}+07$ & $9.72 \mathrm{E}+07$ \\
Cs-137 & $7.40 \mathrm{E}+00$ & $6.32 \mathrm{E}+08$ & $8.87 \mathrm{E}+08$ \\
Co-60 & $2.33 \mathrm{E}+01$ & $1.99 \mathrm{E}+09$ & $2.79 \mathrm{E}+09$ \\
Eu-152 & $5.90 \mathrm{E}-02$ & $5.04 \mathrm{E}+06$ & $7.07 \mathrm{E}+06$ \\
\hline
\end{tabular}

a The following assumptions were made in calculating the residual concentration. It is most likely that all the contamination was in top few $\mathrm{cm}$ of concrete and was removed during decontamination of the trickle filter. For the ALARA analysis, it was assumed that all the concrete which is removed is still uniformly contaminated to $1 / 10$ of the maximum observed in sediment/vacuum debris obtained from the structure. Trickle filter decontaminated concrete volume $=1,546-190.4=1,355.6 \mathrm{ft}^{3}=85.36$ tons (concrete density is assumed to be $\left.2.2 \mathrm{~g} / \mathrm{cm}^{3}\right)$. Radioactivity assumed to be left $(1 / 10$ of the original contamination) in decontaminated concrete which would go to the construction and debris landfill.

TABLE C.6 Trickle Filter Decontaminated Concrete Doses to the Construction Worker, Driver, Landfill Worker, Transportation Population, and Future Resident

\begin{tabular}{|c|c|c|c|c|c|c|}
\hline Radionuclides & $\begin{array}{l}\text { Landfill } \\
\text { Worker } \\
\text { (mrem) }\end{array}$ & $\begin{array}{c}\text { Future Resident } \\
\text { from Burial } \\
\text { (mrem/yr) }\end{array}$ & $\begin{array}{c}\text { Driver } \\
(\mathrm{mrem})\end{array}$ & $\begin{array}{c}\text { Collective } \\
\text { Transportation } \\
\text { (person-rem) }\end{array}$ & $\begin{array}{l}\text { Construction } \\
\text { Worker } \\
(\mathrm{mrem}) \\
\end{array}$ & $\begin{array}{c}\text { LLW } \\
\text { Transportation } \\
\text { (person-rem) }\end{array}$ \\
\hline Am-241 & $1.68 \mathrm{E}-05$ & $1.88 \mathrm{E}-03$ & $2.37 \mathrm{E}-08$ & $3.52 \mathrm{E}-12$ & 4.77E-05 & $7.41 \mathrm{E}-11$ \\
\hline $\mathrm{Pu}-238$ & $3.82 \mathrm{E}-05$ & $1.66 \mathrm{E}-04$ & $4.56 \mathrm{E}-11$ & $4.78 \mathrm{E}-15$ & $1.05 \mathrm{E}-04$ & $1.01 \mathrm{E}-13$ \\
\hline $\mathrm{Pu}-239$ & $1.45 \mathrm{E}-05$ & $6.34 \mathrm{E}-05$ & $4.61 \mathrm{E}-10$ & $1.42 \mathrm{E}-13$ & $3.99 \mathrm{E}-05$ & $2.99 \mathrm{E}-12$ \\
\hline $\mathrm{Ra}-226$ & $2.65 \mathrm{E}-04$ & $2.47 \mathrm{E}-01$ & $5.18 \mathrm{E}-04$ & $1.63 \mathrm{E}-07$ & $1.37 \mathrm{E}-02$ & $3.43 \mathrm{E}-06$ \\
\hline U-234 & $8.34 \mathrm{E}-05$ & $2.37 \mathrm{E}-04$ & $6.14 \mathrm{E}-09$ & $1.34 \mathrm{E}-12$ & $1.76 \mathrm{E}-04$ & $2.82 \mathrm{E}-11$ \\
\hline U-235 & $6.13 \mathrm{E}-06$ & $2.75 \mathrm{E}-04$ & $1.75 \mathrm{E}-06$ & $5.38 \mathrm{E}-10$ & $5.81 \mathrm{E}-05$ & $1.13 \mathrm{E}-08$ \\
\hline U-238 & $2.49 \mathrm{E}-04$ & $4.60 \mathrm{E}-03$ & $1.44 \mathrm{E}-05$ & 4.33E-09 & $8.91 \mathrm{E}-02$ & $9.11 \mathrm{E}-08$ \\
\hline Sr-90 & $1.32 \mathrm{E}-06$ & $2.16 \mathrm{E}-02$ & $0.00 \mathrm{E}+00$ & $0.00 \mathrm{E}+00$ & $5.17 \mathrm{E}-05$ & $0.00 \mathrm{E}+00$ \\
\hline Cs-137 & $8.84 \mathrm{E}-04$ & $8.97 \mathrm{E}-02$ & $1.77 \mathrm{E}-03$ & $5.58 \mathrm{E}-07$ & $4.72 \mathrm{E}-02$ & $1.18 \mathrm{E}-05$ \\
\hline Co-60 & $1.33 \mathrm{E}-02$ & $1.10 \mathrm{E}+00$ & $2.63 \mathrm{E}-02$ & $8.27 \mathrm{E}-06$ & $6.48 \mathrm{E}-01$ & $1.74 \mathrm{E}-04$ \\
\hline Eu-152 & $1.46 \mathrm{E}-05$ & $1.21 \mathrm{E}-03$ & $2.82 \mathrm{E}-05$ & $8.88 \mathrm{E}-09$ & $7.45 \mathrm{E}-04$ & $1.87 \mathrm{E}-07$ \\
\hline Total dose & $1.49 \mathrm{E}-02$ & $1.47 \mathrm{E}+00$ & $2.86 \mathrm{E}-02$ & $9.01 \mathrm{E}-06$ & $8.00 \mathrm{E}-01$ & $1.90 \mathrm{E}-04$ \\
\hline
\end{tabular}


TABLE C.7 Radionuclide Concentration ${ }^{a}$ in Trickle Filter Concrete with No Decontamination

\begin{tabular}{lcc}
\hline & $\begin{array}{c}\text { Trickle Filter's } \\
\text { Concrete Concentration } \\
(\mathrm{pCi} / \mathrm{g})\end{array}$ & $\begin{array}{c}\text { Total Activity in 97.35 Tons } \\
\text { Concrete from Trickle Filter } \\
\text { Radionuclides }\end{array}$ \\
\hline Am-241 & $6.37 \mathrm{E}-02$ & $6.20 \mathrm{E}+06$ \\
$\mathrm{Pu}-238$ & $1.66 \mathrm{E}-01$ & $1.61 \mathrm{E}+07$ \\
$\mathrm{Pu}-239$ & $5.69 \mathrm{E}-02$ & $5.54 \mathrm{E}+06$ \\
Ra-226 & $1.39 \mathrm{E}+00$ & $1.35 \mathrm{E}+08$ \\
$\mathrm{U}-234$ & $1.08 \mathrm{E}+00$ & $1.05 \mathrm{E}+08$ \\
$\mathrm{U}-235$ & $7.21 \mathrm{E}-02$ & $7.02 \mathrm{E}+06$ \\
$\mathrm{U}-238$ & $3.41 \mathrm{E}+00$ & $3.32 \mathrm{E}+08$ \\
Sr-90 & $1.71 \mathrm{E}+00$ & $1.66 \mathrm{E}+08$ \\
Cs-137 & $1.56 \mathrm{E}+01$ & $1.52 \mathrm{E}+09$ \\
Co-60 & $4.91 \mathrm{E}+01$ & $4.78 \mathrm{E}+09$ \\
Eu-152 & $1.24 \mathrm{E}-01$ & $1.21 \mathrm{E}+07$ \\
\hline
\end{tabular}

a For calculating radionuclide concentration in total concrete, it was assumed that concrete volume which was removed in decontamination (i.e., $190.4 \mathrm{ft}^{3}$ [11.989 tons]) of trickle filter is uniformly contaminated to the maximum observed contamination. This total activity is mixed with rest of the concrete volume, which was assumed to be at $1 / 10$ level of contamination. Therefore, for the trickle filter, the radionuclide contamination $=(85.36+11.989 \times 10) /$ $(85.36+11.989)=2.108$ times the contamination in Table C.6. If no decontamination was done and the total concrete was removed and was sent to $\mathrm{C} \& \mathrm{D}$ landfill or was used for constructing road base, the trickle filter concrete volume would be $1,546 \mathrm{ft}^{3}=97.35$ tons (concrete density is assumed to be $2.2 \mathrm{~g} / \mathrm{cm}^{3}$ ). 
TABLE C.8 Trickle Filter Contaminated Concrete Doses to the Construction Worker, Driver, Landfill Worker, Transportation Population, and Future Resident (Distance to the C\&D landfill $=40 \mathrm{~km}$ )

\begin{tabular}{lcccccc}
\hline & $\begin{array}{c}\text { Landfill } \\
\text { Worker } \\
\text { Radionuclides }\end{array}$ & $\begin{array}{c}\text { Future Resident } \\
\text { from Burial } \\
(\mathrm{mrem} / \mathrm{yr})\end{array}$ & $\begin{array}{c}\text { Driver } \\
\text { (mrem) }\end{array}$ & $\begin{array}{c}\text { Collective } \\
\text { Transportation } \\
\text { (person-rem) }\end{array}$ & $\begin{array}{c}\text { Construction } \\
\text { Worker } \\
(m r e m)\end{array}$ & $\begin{array}{c}\text { LLW } \\
\text { Transportation } \\
\text { (person-rem) }\end{array}$ \\
\hline & & & & & & \\
Am-241 & $4.03 \mathrm{E}-05$ & $4.52 \mathrm{E}-03$ & $5.70 \mathrm{E}-08$ & $8.45 \mathrm{E}-12$ & $1.15 \mathrm{E}-04$ & $1.27 \mathrm{E}-10$ \\
Pu-238 & $9.19 \mathrm{E}-05$ & $3.98 \mathrm{E}-04$ & $1.10 \mathrm{E}-10$ & $1.15 \mathrm{E}-14$ & $2.53 \mathrm{E}-04$ & $1.72 \mathrm{E}-13$ \\
Pu-239 & $3.49 \mathrm{E}-05$ & $1.52 \mathrm{E}-04$ & $1.11 \mathrm{E}-09$ & $3.41 \mathrm{E}-13$ & $9.59 \mathrm{E}-05$ & $5.12 \mathrm{E}-12$ \\
Ra-226 & $6.37 \mathrm{E}-04$ & $5.93 \mathrm{E}-01$ & $1.25 \mathrm{E}-03$ & $3.91 \mathrm{E}-07$ & $3.30 \mathrm{E}-02$ & $5.87 \mathrm{E}-06$ \\
$\mathrm{U}-234$ & $2.00 \mathrm{E}-04$ & $5.70 \mathrm{E}-04$ & $1.48 \mathrm{E}-08$ & $3.22 \mathrm{E}-12$ & $4.23 \mathrm{E}-04$ & $4.82 \mathrm{E}-11$ \\
$\mathrm{U}-235$ & $1.47 \mathrm{E}-05$ & $6.62 \mathrm{E}-04$ & $4.21 \mathrm{E}-06$ & $1.29 \mathrm{E}-09$ & $1.40 \mathrm{E}-04$ & $1.94 \mathrm{E}-08$ \\
$\mathrm{U}-238$ & $5.98 \mathrm{E}-04$ & $1.11 \mathrm{E}-02$ & $3.46 \mathrm{E}-05$ & $1.04 \mathrm{E}-08$ & $2.14 \mathrm{E}-01$ & $1.56 \mathrm{E}-07$ \\
Sr-90 & $3.16 \mathrm{E}-06$ & $5.19 \mathrm{E}-02$ & $0.00 \mathrm{E}+00$ & $0.00 \mathrm{E}+00$ & $1.24 \mathrm{E}-04$ & $0.00 \mathrm{E}+00$ \\
Cs-137 & $2.13 \mathrm{E}-03$ & $2.16 \mathrm{E}-01$ & $4.25 \mathrm{E}-03$ & $1.34 \mathrm{E}-06$ & $1.13 \mathrm{E}-01$ & $2.01 \mathrm{E}-05$ \\
Co-60 & $3.20 \mathrm{E}-02$ & $2.64 \mathrm{E}+00$ & $6.31 \mathrm{E}-02$ & $1.99 \mathrm{E}-05$ & $1.56 \mathrm{E}+00$ & $2.98 \mathrm{E}-04$ \\
Eu-152 & $3.51 \mathrm{E}-05$ & $2.92 \mathrm{E}-03$ & $6.78 \mathrm{E}-05$ & $2.14 \mathrm{E}-08$ & $1.79 \mathrm{E}-03$ & $3.20 \mathrm{E}-07$ \\
\hline & & & & & & \\
Total dose & $3.58 \mathrm{E}-02$ & $3.53 \mathrm{E}+00$ & $6.87 \mathrm{E}-02$ & $2.17 \mathrm{E}-05$ & $1.92 \mathrm{E}+00$ & $3.25 \mathrm{E}-04$ \\
\hline
\end{tabular}


APPENDIX D:

INEEL-SPECIFIC COST AND DOSE ANALYSIS FOR CONCRETE DISPOSITION FROM TRICKLE FILTER STRUCTURE 


$$
\text { D-2 }
$$




\section{APPENDIX D: \\ INEEL-SPECIFIC COST AND DOSE ANALYSIS FOR CONCRETE DISPOSITION FROM TRICKLE FILTER STRUCTURE}

Appendix D provides the cost and dose analysis for disposition alternatives for the trickle filter concrete for the INEEL-specific case. Table D.1 lists all cost parameters used in the analysis. Table D.2 provides the cost calculations for decontamination, demolition, crushing, waste packaging, shipment, transportation, and disposal. Table D.3 lists the unit dose factors from Arnish et al. (2000) for radionuclides found at Central Facility Area 691. Table D.4 gives the observed radionuclide concentrations in the sediment sample from the trickle filter structure. Tables D.5 and D.7 provide the concrete residual radionuclide concentrations used for calculations after decontamination (Table D.5) and when no decontamination was done at the trickle filter structure (Table D.7). Tables D.6 and D.8 give the estimated doses to different receptors after decontamination (Table D.6) and when no decontamination was done (Table D.8). 
TABLE D.1 Cost Assumptions for Trickle Filter Disposal Alternatives for INEEL-Specific Case

\begin{tabular}{|c|c|}
\hline Cost Parameters & Value \\
\hline LLW disposal cost, $\$ / \mathrm{ft}^{3}$ & 0 \\
\hline Cost to transport $\mathrm{C} \& \mathrm{D}$ waste, $\$ / \mathrm{yd}^{3} / \mathrm{mi}$ & 0.42 \\
\hline Disposal cost of C\&D waste, $\$ / \mathrm{yd}^{3}$ & 54.3 \\
\hline Distance to LLW facility, mi (km) & $10(20)^{\mathrm{a}}$ \\
\hline Distance to C\&D facility, mi $(\mathrm{km})$ & $2(4)^{\mathrm{a}}$ \\
\hline Concrete crushing cost, \$/MT & 10.63 \\
\hline D\&D equipment lifetime floor (wall), yr & $10(10)$ \\
\hline D\&D equipment interest rate, $\%$ & 8 \\
\hline D\&D equipment use time floor (wall), $h$ & $168(168)$ \\
\hline Demolishing cost, $\$ / \mathrm{ft}^{2}$ & 1 \\
\hline Floor decon equipment purchase cost, $\$$ & 100,000 \\
\hline Wall decon equipment purchase cost, $\$$ & 200,000 \\
\hline DECON worker hourly cost, $\$$ & 50 \\
\hline Floor DECON production rate, $\mathrm{ft}^{2} / \mathrm{h} /$ pass & 200 \\
\hline Wall DECON production rate, $\mathrm{ft}^{2} / \mathrm{h} /$ pass & 150 \\
\hline Floor DECON process cost, $\$ / \mathrm{ft}^{2} /$ pass & 5 \\
\hline Wall DECON process cost, $\$ / \mathrm{ft}^{2} /$ pass & 10 \\
\hline Floor removal rate, in./pass & 0.5 \\
\hline Wall removal rate, in./pass & 0.25 \\
\hline Concrete density, $\mathrm{g} / \mathrm{cm}^{3}$ & 2.2 \\
\hline Volume to mass conversion, $\mathrm{MT} / \mathrm{ft}^{3}$ & 0.06297 \\
\hline Container cost per container for 55 -gal drum, $\$$ & 50 \\
\hline Container cost per container for B-25 type, $\$$ & 790 \\
\hline Unit loading cost for 55 -gal drum, $\$$ & 100 \\
\hline Unit loading cost for B-25 type container, $\$$ & 160 \\
\hline Fixed cost per shipment for 55-gal drums, $\$$ & 880 \\
\hline Fixed cost per shipment for B-25 type containers, $\$$ & 335 \\
\hline Cost per shipment-mile for 55-gal drums, $\$$ & 4 \\
\hline Cost per shipment-mile for B-25 type container, $\$$ & 1.43 \\
\hline Total concrete volume of Trickle filter, $\mathrm{ft}^{3}$ & 1546 \\
\hline Floor area, $\mathrm{ft}^{2}$ & 1960 \\
\hline Wall area, $\mathrm{ft}^{2}$ & 1280 \\
\hline
\end{tabular}

a For sake of conservatism in analysis, distance values have been rounded up when converted from miles to kilometers. 
TABLE D.2 Cost Calculations for Decontamination, Demolition, Packaging, Transportation, and Disposal

\begin{tabular}{|c|c|}
\hline Component & Value \\
\hline \multicolumn{2}{|l|}{ Decontamination Cost Calculations } \\
\hline Floor DECON depth, in. & 1 \\
\hline Wall DECON depth, in. & 0.25 \\
\hline Waste for floor decon, $\mathrm{ft}^{3}$ & 164 \\
\hline Waste for wall decon, $\mathrm{ft}^{3}$ & 27 \\
\hline Total waste generated, $\mathrm{ft}^{3}$ & 190 \\
\hline Amortization cost for floor equipment, $\$ / \mathrm{h}$ & 1.70 \\
\hline Amortization cost for wall equipment, $\$ / \mathrm{h}$ & 3.40 \\
\hline Decon cost (floors), $\$$ & 20,900 \\
\hline Decon cost (walls), \$ & 13,800 \\
\hline Total decontamination cost, $\$$ & 34,700 \\
\hline Demolition Cost for Entire Concrete Building, $\$$ & 3,245 \\
\hline \multicolumn{2}{|l|}{ Crushing Cost } \\
\hline Entire concrete building, $\$$ & 1,035 \\
\hline Remaining building (after decontamination), \$ & 854 \\
\hline \multicolumn{2}{|l|}{ Fines Generated } \\
\hline Entire concrete building, MT & 29 \\
\hline Remaining building after decontamination, MT & 26 \\
\hline \multicolumn{2}{|l|}{ Decon Waste Packaging } \\
\hline Number of 55 gallon drums & 2 \\
\hline Number of B-25 type boxes & 2 \\
\hline LLW packaging cost, $\$$ & 2,200 \\
\hline \multicolumn{2}{|l|}{ Packaging for $L L W$} \\
\hline Number of B-25 type boxes (entire structure to LLW ) & 27 \\
\hline Packaging cost, $\$$ & 25,482 \\
\hline \multicolumn{2}{|l|}{ Shipments } \\
\hline Number of shipments (entire structure to LLW) & 6 \\
\hline Number of shipments (decontamination waste to LLW) & 1 \\
\hline \multicolumn{2}{|l|}{ Transportation Costs } \\
\hline Entire structure to LLW, $\$$ & 2,096 \\
\hline Decontaminated waste to LLW, \$ & 349 \\
\hline Decontaminated structure to $\mathrm{C} \& \mathrm{D}, \$$ & 42 \\
\hline Entire structure to $\mathrm{C} \& \mathrm{D}, \$$ & 48 \\
\hline \multicolumn{2}{|l|}{ Disposal Costs } \\
\hline Entire structure to LLW, \$ & 0 \\
\hline Entire structure to $C \& D, \$$ & 3,109 \\
\hline Decontaminated structure to $C \& D, \$$ & 2,727 \\
\hline LLW to LLW site, $\$$ & 0 \\
\hline
\end{tabular}


TABLE D.3 Unit Dose Factors from Concrete Protocol Report for Radionuclides Found at Central Facility Area 691

\begin{tabular}{|c|c|c|c|c|c|}
\hline Radionuclide & $\begin{array}{c}\text { Landfill } \\
\text { Worker } \\
\text { (mrem/pCi) }\end{array}$ & $\begin{array}{c}\text { Burial Dose } \\
\text { (mrem/yr per pCi/g } \\
\text { per ton concrete) }\end{array}$ & $\begin{array}{c}\text { Driver Dose } \\
(\mathrm{mrem} / \mathrm{pCi} / \mathrm{km})\end{array}$ & $\begin{array}{c}\text { Collective } \\
\text { Dose (person- } \\
\text { rem } / \mathrm{pCi} / \mathrm{km}) \\
\end{array}$ & $\begin{array}{c}\text { Construction } \\
\text { Worker } \\
\text { (mrem/yr/pCi/g/ton) }\end{array}$ \\
\hline Am-241 & $6.50 \mathrm{E}-12$ & 7.29E-04 & $2.30 \mathrm{E}-16$ & $3.41 \mathrm{E}-20$ & $1.85 \mathrm{E}-05$ \\
\hline Pu-238 & $5.70 \mathrm{E}-12$ & $2.47 \mathrm{E}-05$ & $1.70 \mathrm{E}-19$ & $1.78 \mathrm{E}-23$ & $1.57 \mathrm{E}-05$ \\
\hline Pu-239 & $6.30 \mathrm{E}-12$ & $2.75 \mathrm{E}-05$ & $5.00 \mathrm{E}-18$ & $1.54 \mathrm{E}-21$ & $1.73 \mathrm{E}-05$ \\
\hline $\mathrm{Ra}-226+\mathrm{D}$ & $4.70 \mathrm{E}-12$ & $4.38 \mathrm{E}-03$ & $2.30 \mathrm{E}-13$ & $7.22 \mathrm{E}-17$ & $2.44 \mathrm{E}-04$ \\
\hline U-234 & $1.90 \mathrm{E}-12$ & $5.40 \mathrm{E}-06$ & $3.50 \mathrm{E}-18$ & 7.62E-22 & 4.01E-06 \\
\hline $\mathrm{U}-235+\mathrm{D}$ & $2.10 \mathrm{E}-12$ & $9.43 \mathrm{E}-05$ & $1.50 \mathrm{E}-14$ & $4.61 \mathrm{E}-18$ & $1.99 \mathrm{E}-05$ \\
\hline $\mathrm{U}-238+\mathrm{D}$ & $1.80 \mathrm{E}-12$ & 3.33E-05 & $2.60 \mathrm{E}-15$ & $7.82 \mathrm{E}-19$ & $6.44 \mathrm{E}-04$ \\
\hline Sr-90 & $1.90 \mathrm{E}-14$ & $3.12 \mathrm{E}-04$ & $0.00 \mathrm{E}+00$ & $0.00 \mathrm{E}+00$ & 7.47E-07 \\
\hline Cs $-137+\mathrm{D}$ & $1.40 \mathrm{E}-12$ & $1.42 \mathrm{E}-04$ & $7.00 \mathrm{E}-14$ & $2.21 \mathrm{E}-17$ & 7.47E-05 \\
\hline Сo-60 & $6.70 \mathrm{E}-12$ & $5.53 \mathrm{E}-04$ & $3.30 \mathrm{E}-13$ & $1.04 \mathrm{E}-16$ & $3.26 \mathrm{E}-04$ \\
\hline Eu-152 & $2.90 \mathrm{E}-12$ & $2.41 \mathrm{E}-04$ & $1.40 \mathrm{E}-13$ & $4.41 \mathrm{E}-17$ & $1.48 \mathrm{E}-04$ \\
\hline
\end{tabular}

TABLE D.4 Measured Radionuclide Concentration in the Sediment Sample from the Trickle Filter Structure

\begin{tabular}{lc}
\hline & \\
Radionuclides & Sediment $(\mathrm{pCi} / \mathrm{g})$ \\
\hline & \\
$\mathrm{Am}-241$ & 0.302 \\
$\mathrm{Pu}-238$ & 0.786 \\
$\mathrm{Pu}-239$ & 0.27 \\
$\mathrm{Ra}-226$ & 6.6 \\
$\mathrm{U}-234$ & 5.14 \\
$\mathrm{U}-235$ & 0.342 \\
$\mathrm{U}-238$ & 16.2 \\
$\mathrm{Sr}-90$ & 8.11 \\
$\mathrm{Cs}-137$ & 74 \\
$\mathrm{Co}-60$ & 233 \\
Eu-152 & 0.59 \\
\hline
\end{tabular}


TABLE D.5 Residual Radionuclide Concentration in Trickle Filter Concrete after Decontamination ${ }^{\mathrm{a}}$

\begin{tabular}{lccc}
\hline & $\begin{array}{c}\text { Trickle Filter's } \\
\text { Decontaminated Concrete } \\
\text { Concentration }(p C i / g)\end{array}$ & $\begin{array}{c}\text { Total Activity in 85.36 Tons } \\
\text { Trickle Filter Decontaminated } \\
\text { Concrete }(p C i)\end{array}$ & $\begin{array}{c}\text { Total Activity in 11.99 } \\
\text { Tons of Trickle Filter } \\
\text { Waste (pCi) }\end{array}$ \\
\hline Am-241 & $3.02 \mathrm{E}-02$ & $2.58 \mathrm{E}+06$ & $3.62 \mathrm{E}+06$ \\
$\mathrm{Pu}-238$ & $7.86 \mathrm{E}-02$ & $6.71 \mathrm{E}+06$ & $9.42 \mathrm{E}+06$ \\
$\mathrm{Pu}-239$ & $2.70 \mathrm{E}-02$ & $2.30 \mathrm{E}+06$ & $3.24 \mathrm{E}+06$ \\
$\mathrm{Ra}-226$ & $6.60 \mathrm{E}-01$ & $5.63 \mathrm{E}+07$ & $7.91 \mathrm{E}+07$ \\
$\mathrm{U}-234$ & $5.14 \mathrm{E}-01$ & $4.39 \mathrm{E}+07$ & $6.16 \mathrm{E}+07$ \\
$\mathrm{U}-235$ & $3.42 \mathrm{E}-02$ & $2.92 \mathrm{E}+06$ & $4.10 \mathrm{E}+06$ \\
$\mathrm{U}-238$ & $1.62 \mathrm{E}+00$ & $1.38 \mathrm{E}+08$ & $1.94 \mathrm{E}+08$ \\
$\mathrm{Sr}-90$ & $8.11 \mathrm{E}-01$ & $6.92 \mathrm{E}+07$ & $9.72 \mathrm{E}+07$ \\
$\mathrm{Cs}-137$ & $7.40 \mathrm{E}+00$ & $6.32 \mathrm{E}+08$ & $8.87 \mathrm{E}+08$ \\
$\mathrm{Co}-60$ & $2.33 \mathrm{E}+01$ & $1.99 \mathrm{E}+09$ & $2.79 \mathrm{E}+09$ \\
$\mathrm{Eu}-152$ & $5.90 \mathrm{E}-02$ & $5.04 \mathrm{E}+06$ & $7.07 \mathrm{E}+06$ \\
\hline
\end{tabular}

a The following assumptions were made in calculating the residual concentration. It is most likely that all the contamination was in top few $\mathrm{cm}$ of concrete and was removed during decontamination of the trickle filter. For the ALARA analysis, it was assumed that all the concrete which is removed is still uniformly contaminated to $1 / 10$ of the maximum observed in sediment/vacuum debris obtained from the structure. Trickle filter decontaminated concrete volume $=1,546-190.4=1,355.6 \mathrm{ft}^{3}=85.36$ tons (concrete density is assumed to be $\left.2.2 \mathrm{~g} / \mathrm{cm}^{3}\right)$. Radioactivity assumed to be left $(1 / 10$ of the original contamination) in decontaminated concrete which would go to the construction and debris landfill.

TABLE D.6 Trickle Filter Decontaminated Concrete Doses to the Construction Worker, Driver, Landfill Worker, Transportation Population, and Future Resident

\begin{tabular}{|c|c|c|c|c|c|c|}
\hline Radionuclides & $\begin{array}{l}\text { Landfill } \\
\text { Worker } \\
\text { (mrem) }\end{array}$ & $\begin{array}{c}\text { Future Resident } \\
\text { from Burial } \\
\text { (mrem/yr) }\end{array}$ & $\begin{array}{c}\text { Driver } \\
(\mathrm{mrem})\end{array}$ & $\begin{array}{c}\text { Collective } \\
\text { Transportation } \\
\text { (person-rem) }\end{array}$ & $\begin{array}{l}\text { Construction } \\
\text { Worker } \\
(\mathrm{mrem}) \\
\end{array}$ & $\begin{array}{c}\text { LLW } \\
\text { Transportation } \\
\text { (person-rem) }\end{array}$ \\
\hline Am-241 & $1.68 \mathrm{E}-05$ & $1.88 \mathrm{E}-03$ & 2.37E-09 & $3.52 \mathrm{E}-13$ & 4.77E-05 & $2.47 \mathrm{E}-12$ \\
\hline $\mathrm{Pu}-238$ & $3.82 \mathrm{E}-05$ & $1.66 \mathrm{E}-04$ & $4.56 \mathrm{E}-12$ & $4.78 \mathrm{E}-16$ & $1.05 \mathrm{E}-04$ & $3.35 \mathrm{E}-15$ \\
\hline $\mathrm{Pu}-239$ & $1.45 \mathrm{E}-05$ & $6.34 \mathrm{E}-05$ & $4.61 \mathrm{E}-11$ & $1.42 \mathrm{E}-14$ & $3.99 \mathrm{E}-05$ & $9.97 \mathrm{E}-14$ \\
\hline Ra-226 & $2.65 \mathrm{E}-04$ & $2.47 \mathrm{E}-01$ & $5.18 \mathrm{E}-05$ & $1.63 \mathrm{E}-08$ & $1.37 \mathrm{E}-02$ & $1.14 \mathrm{E}-07$ \\
\hline U-234 & $8.34 \mathrm{E}-05$ & $2.37 \mathrm{E}-04$ & $6.14 \mathrm{E}-10$ & $1.34 \mathrm{E}-13$ & $1.76 \mathrm{E}-04$ & $9.39 \mathrm{E}-13$ \\
\hline U-235 & $6.13 \mathrm{E}-06$ & $2.75 \mathrm{E}-04$ & $1.75 \mathrm{E}-07$ & $5.38 \mathrm{E}-11$ & $5.81 \mathrm{E}-05$ & $3.78 \mathrm{E}-10$ \\
\hline $\mathrm{U}-238$ & $2.49 \mathrm{E}-04$ & $4.60 \mathrm{E}-03$ & $1.44 \mathrm{E}-06$ & $4.33 \mathrm{E}-10$ & $8.91 \mathrm{E}-02$ & $3.04 \mathrm{E}-09$ \\
\hline Sr-90 & $1.32 \mathrm{E}-06$ & $2.16 \mathrm{E}-02$ & $0.00 \mathrm{E}+00$ & $0.00 \mathrm{E}+00$ & $5.17 \mathrm{E}-05$ & $0.00 \mathrm{E}+00$ \\
\hline Cs-137 & $8.84 \mathrm{E}-04$ & $8.97 \mathrm{E}-02$ & $1.77 \mathrm{E}-04$ & $5.58 \mathrm{E}-08$ & $4.72 \mathrm{E}-02$ & 3.92E-07 \\
\hline Co-60 & $1.33 \mathrm{E}-02$ & $1.10 \mathrm{E}+00$ & $2.63 \mathrm{E}-03$ & $8.27 \mathrm{E}-07$ & $6.48 \mathrm{E}-01$ & $5.81 \mathrm{E}-06$ \\
\hline Eu-152 & $1.46 \mathrm{E}-05$ & $1.21 \mathrm{E}-03$ & $2.82 \mathrm{E}-06$ & $8.88 \mathrm{E}-10$ & $7.45 \mathrm{E}-04$ & $6.24 \mathrm{E}-09$ \\
\hline Total dose & $1.49 \mathrm{E}-02$ & $1.47 \mathrm{E}+00$ & $2.86 \mathrm{E}-03$ & $9.01 \mathrm{E}-07$ & $8.00 \mathrm{E}-01$ & $6.33 \mathrm{E}-06$ \\
\hline
\end{tabular}


TABLE D.7 Radionuclide Concentration ${ }^{\mathrm{a}}$ in Trickle Filter Concrete with No Decontamination

\begin{tabular}{lcc}
\hline & $\begin{array}{c}\text { Trickle Filter's } \\
\text { Concrete Concentration } \\
(\mathrm{pCi} / \mathrm{g})\end{array}$ & $\begin{array}{c}\text { Total Activity in 97.35 Tons } \\
\text { Concrete from Trickle Filter } \\
\text { Radionuclides }\end{array}$ \\
\hline Am-241 & $6.37 \mathrm{E}-02$ & $6.20 \mathrm{E}+06$ \\
$\mathrm{Pu}-238$ & $1.66 \mathrm{E}-01$ & $1.61 \mathrm{E}+07$ \\
$\mathrm{Pu}-239$ & $5.69 \mathrm{E}-02$ & $5.54 \mathrm{E}+06$ \\
$\mathrm{Ra}-226$ & $1.39 \mathrm{E}+00$ & $1.35 \mathrm{E}+08$ \\
$\mathrm{U}-234$ & $1.08 \mathrm{E}+00$ & $1.05 \mathrm{E}+08$ \\
$\mathrm{U}-235$ & $7.21 \mathrm{E}-02$ & $7.02 \mathrm{E}+06$ \\
$\mathrm{U}-238$ & $3.41 \mathrm{E}+00$ & $3.32 \mathrm{E}+08$ \\
$\mathrm{Sr}-90$ & $1.71 \mathrm{E}+00$ & $1.66 \mathrm{E}+08$ \\
$\mathrm{Cs}-137$ & $1.56 \mathrm{E}+01$ & $1.52 \mathrm{E}+09$ \\
$\mathrm{Co}-60$ & $4.91 \mathrm{E}+01$ & $4.78 \mathrm{E}+09$ \\
$\mathrm{Eu}-152$ & $1.24 \mathrm{E}-01$ & $1.21 \mathrm{E}+07$ \\
\hline
\end{tabular}

a For calculating radionuclide concentration in total concrete, it was assumed that concrete volume which was removed in decontamination (i.e., $190.4 \mathrm{ft}^{3}$ [11.989 tons]) of trickle filter is uniformly contaminated to the maximum observed contamination. This total activity is mixed with rest of the concrete volume, which was assumed to be at 1/10 level of contamination. Therefore, for the trickle filter, the radionuclide contamination $=(85.36+11.989 \times 10) /$ $(85.36+11.989)=2.108$ times the contamination in Table C.6. If no decontamination was done and the total concrete was removed and was sent to $\mathrm{C} \& \mathrm{D}$ landfill or was used for constructing road base, the trickle filter concrete volume would be $1,546 \mathrm{ft}^{3}=97.35$ tons (concrete density is assumed to be $2.2 \mathrm{~g} / \mathrm{cm}^{3}$ ). 
TABLE D.8 Trickle Filter Contaminated Concrete Doses to the Construction Worker, Driver, Landfill Worker, Transportation Population, and Future Resident (Distance to the C\&D landfill $=40 \mathrm{~km}$ )

\begin{tabular}{lcccccc}
\hline & $\begin{array}{c}\text { Landfill } \\
\text { Worker } \\
\text { Radionuclides }\end{array}$ & $\begin{array}{c}\text { Future Resident } \\
\text { from Burial } \\
(\mathrm{mrem} / \mathrm{yr})\end{array}$ & $\begin{array}{c}\text { Driver } \\
\text { (mrem) }\end{array}$ & $\begin{array}{c}\text { Collective } \\
\text { Transportation } \\
\text { (person-rem) }\end{array}$ & $\begin{array}{c}\text { Construction } \\
\text { Worker } \\
(m r e m)\end{array}$ & $\begin{array}{c}\text { LLW } \\
\text { Transportation } \\
\text { (person-rem) }\end{array}$ \\
\hline & & & & & & \\
Am-241 & $4.03 \mathrm{E}-05$ & $4.52 \mathrm{E}-03$ & $5.70 \mathrm{E}-09$ & $8.45 \mathrm{E}-13$ & $1.15 \mathrm{E}-04$ & $4.23 \mathrm{E}-12$ \\
Pu-238 & $9.19 \mathrm{E}-05$ & $3.98 \mathrm{E}-04$ & $1.10 \mathrm{E}-11$ & $1.15 \mathrm{E}-15$ & $2.53 \mathrm{E}-04$ & $5.74 \mathrm{E}-15$ \\
Pu-239 & $3.49 \mathrm{E}-05$ & $1.52 \mathrm{E}-04$ & $1.11 \mathrm{E}-10$ & $3.41 \mathrm{E}-14$ & $9.59 \mathrm{E}-05$ & $1.17 \mathrm{E}-13$ \\
Ra-226 & $6.37 \mathrm{E}-04$ & $5.93 \mathrm{E}-01$ & $1.25 \mathrm{E}-04$ & $3.91 \mathrm{E}-08$ & $3.30 \mathrm{E}-02$ & $1.96 \mathrm{E}-07$ \\
$\mathrm{U}-234$ & $2.00 \mathrm{E}-04$ & $5.70 \mathrm{E}-04$ & $1.48 \mathrm{E}-09$ & $3.22 \mathrm{E}-13$ & $4.23 \mathrm{E}-04$ & $1.61 \mathrm{E}-12$ \\
$\mathrm{U}-235$ & $1.47 \mathrm{E}-05$ & $6.62 \mathrm{E}-04$ & $4.21 \mathrm{E}-07$ & $1.29 \mathrm{E}-10$ & $1.40 \mathrm{E}-04$ & $6.47 \mathrm{E}-10$ \\
U-238 & $5.98 \mathrm{E}-04$ & $1.11 \mathrm{E}-02$ & $3.46 \mathrm{E}-06$ & $1.04 \mathrm{E}-09$ & $2.14 \mathrm{E}-01$ & $5.20 \mathrm{E}-09$ \\
Sr-90 & $3.16 \mathrm{E}-06$ & $5.19 \mathrm{E}-02$ & $0.00 \mathrm{E}+00$ & $0.00 \mathrm{E}+00$ & $1.24 \mathrm{E}-04$ & $0.00 \mathrm{E}+00$ \\
Cs-137 & $2.13 \mathrm{E}-03$ & $2.16 \mathrm{E}-01$ & $4.25 \mathrm{E}-04$ & $1.34 \mathrm{E}-07$ & $1.13 \mathrm{E}-01$ & $6.71 \mathrm{E}-07$ \\
Co-60 & $3.20 \mathrm{E}-02$ & $2.64 \mathrm{E}+00$ & $6.31 \mathrm{E}-03$ & $1.99 \mathrm{E}-06$ & $1.56 \mathrm{E}+00$ & $9.95 \mathrm{E}-06$ \\
Eu-152 & $3.51 \mathrm{E}-05$ & $2.92 \mathrm{E}-03$ & $6.78 \mathrm{E}-06$ & $2.14 \mathrm{E}-09$ & $1.79 \mathrm{E}-03$ & $1.07 \mathrm{E}-08$ \\
\hline & & & & & & \\
Total dose & $3.58 \mathrm{E}-02$ & $3.53 \mathrm{E}+00$ & $6.87 \mathrm{E}-03$ & $2.17 \mathrm{E}-06$ & $1.92 \mathrm{E}+00$ & $1.08 \mathrm{E}-05$ \\
\hline
\end{tabular}


